\title{
Aerosol characterization over the southeastern United States using high-resolution aerosol mass spectrometry: spatial and seasonal variation of aerosol composition and sources with a focus on organic nitrates
}

\author{
L. Xu ${ }^{1}$, S. Suresh ${ }^{1, \mathrm{a}}$, H. Guo ${ }^{2}$, R. J. Weber ${ }^{2}$, and N. L. $\mathbf{N g}^{1,2}$ \\ ${ }^{1}$ School of Chemical and Biomolecular Engineering, Georgia Institute of Technology, Atlanta, GA, USA \\ ${ }^{2}$ School of Earth and Atmospheric Sciences, Georgia Institute of Technology, Atlanta, GA, USA \\ ${ }^{a}$ now at: ExxonMoBil, Omaha, NE, USA
}

Correspondence to: N. L. Ng (ng@chbe.gatech.edu)

Received: 06 March 2015 - Published in Atmos. Chem. Phys. Discuss.: 09 April 2015

Revised: 17 June 2015 - Accepted: 18 June 2015 - Published: 08 July 2015

\begin{abstract}
We deployed a High-Resolution Time-of-Flight Aerosol Mass Spectrometer (HR-ToF-AMS) and an Aerosol Chemical Speciation Monitor (ACSM) to characterize the chemical composition of submicron non-refractory particulate matter $\left(\mathrm{NR}-\mathrm{PM}_{1}\right)$ in the southeastern USA. Measurements were performed in both rural and urban sites in the greater Atlanta area, Georgia (GA), and Centreville, Alabama (AL), for approximately 1 year as part of Southeastern Center for Air Pollution and Epidemiology study (SCAPE) and Southern Oxidant and Aerosol Study (SOAS). Organic aerosol (OA) accounts for more than half of NR-PM mass $_{1}$ concentration regardless of sampling sites and seasons. Positive matrix factorization (PMF) analysis of HR-ToF-AMS measurements identified various OA sources, depending on location and season. Hydrocarbon-like OA (HOA) and cooking OA (COA) have important, but not dominant, contributions to total OA in urban sites (i.e., $21-38 \%$ of total OA depending on site and season). Biomass burning OA (BBOA) concentration shows a distinct seasonal variation with a larger enhancement in winter than summer. We find a good correlation between BBOA and brown carbon, indicating biomass burning is an important source for brown carbon, although an additional, unidentified brown carbon source is likely present at the rural Yorkville site. Isoprene-derived $\mathrm{OA}$ factor (isoprene-OA) is only deconvolved in warmer months and contributes $18-36 \%$ of total OA. The presence of isoprene-OA factor in urban sites is more likely from local production in the presence of $\mathrm{NO}_{x}$ than transport from rural
\end{abstract}

sites. More-oxidized and less-oxidized oxygenated organic aerosol (MO-OOA and LO-OOA, respectively) are dominant fractions (47-79\%) of OA in all sites. MO-OOA correlates well with ozone in summer but not in winter, indicating MO-OOA sources may vary with seasons. LO-OOA, which reaches a daily maximum at night, correlates better with estimated nitrate functionality from organic nitrates than total nitrates.

Based on the HR-ToF-AMS measurements, we estimate that the nitrate functionality from organic nitrates contributes $63-100 \%$ to the total measured nitrates in summer. Furthermore, the contribution of organic nitrates to total OA is estimated to be $5-12 \%$ in summer, suggesting that organic nitrates are important components in the ambient aerosol in the southeastern USA. The spatial distribution of OA is investigated by comparing simultaneous HR-ToF-AMS measurements with ACSM measurements at two different sampling sites. OA is found to be spatially homogeneous in summer due possibly to stagnant air mass and a dominant amount of regional secondary organic aerosol (SOA) in the southeastern USA. The homogeneity is less in winter, which is likely due to spatial variation of primary emissions.

We observe that the seasonality of OA concentration shows a clear urban/rural contrast. While OA exhibits weak seasonal variation in the urban sites, its concentration is higher in summer than winter for rural sites. This observation from our year-long measurements is consistent with 14 years of organic carbon (OC) data from the SouthEastern 
Aerosol Research and Characterization (SEARCH) network. The comparison between short-term measurements with advanced instruments and long-term measurements of basic air quality indicators not only tests the robustness of the shortterm measurements but also provides insights in interpreting long-term measurements. We find that OA factors resolved from PMF analysis on HR-ToF-AMS measurements have distinctly different diurnal variations. The compensation of OA factors with different diurnal trends is one possible reason for the repeatedly observed, relatively flat OA diurnal profile in the southeastern USA. In addition, analysis of longterm measurements shows that the correlation between OC and sulfate is substantially stronger in summer than winter. This seasonality could be partly due to the effects of sulfate on isoprene SOA formation as revealed by the short-term intensive measurements.

\section{Introduction}

The southeastern USA is an intriguing region to study aerosol formation. Firstly, the fine particulate matter $\left(\mathrm{PM}_{2.5}\right)$ concentration is generally high and often exceeds the National Ambient Air Quality Standards (NAAQS) (Cohan et al., 2007; Blanchard et al., 2013). Secondly, the southeastern USA is characterized by large emissions from both biogenic and anthropogenic sources, which makes it an ideal region to study the effects of interactions between biogenic/anthropogenic emissions on organic aerosol formation and air quality. Roughly half of the land in the southeastern USA is covered by forests which emit large amounts of biogenic volatile organic compounds (VOCs) that are precursors for secondary organic aerosol (SOA) formation (Geron et al., 2000; Guenther et al., 2006). Based on radiocarbon analysis, Schichtel et al. (2008) showed that about $90 \%$ of total carbon is biogenic in a rural site in Tennessee. Similarly, Weber et al. (2007) found that $70-80 \%$ of the watersoluble organic carbon (WSOC, a surrogate for SOA) is of biogenic origin in Atlanta, GA. However, recent studies revealed that the formation of SOA from biogenic VOCs is largely controlled by anthropogenic emissions in the southeastern USA (Weber et al., 2007; Xu et al., 2015). Thirdly, a wide range of air quality data has been routinely collected by the SEARCH (SouthEastern Aerosol Research and Characterization) network, including multiple rural and urban sites in the southeastern USA from 1999 to 2013 (Edgerton et al., 2005; Hansen et al., 2003; Hidy et al., 2014). Combining short-term field campaigns and long-term measurements is useful because short-term field campaigns with state-of-theart instruments can better characterize atmospheric processes and provide insights in interpreting the long-term observations. In turn, long-term measurements of basic air quality parameters are helpful when testing the robustness of shortterm field campaign results (Hidy et al., 2014).
A number of field studies have been conducted to understand the sources of OA in the southeastern USA. Lim and Turpin (2002) showed that $\sim 50 \%$ of OC is secondary in urban Atlanta by using an elemental carbon (EC) tracer method. Blanchard et al. (2008) applied three different empirical models and estimated that the fraction of secondary OC (SOC) in OC is 20-60\% in the southeastern USA, which was higher at rural sites compared to urban sites and higher in summer compared to winter. The authors also showed that the estimated SOC/OC ratio highly depends on the estimation methods. By using WSOC as a surrogate for SOC, Weber et al. (2007) showed that SOC accounts for roughly $75 \%$ of OC in Yorkville (YRK), a rural site in GA, while the contribution of SOC to OC decreases to about $65 \%$ in Georgia Institute of Technology, an urban site. However, these studies were based on bulk properties, such as OC and WSOC, which makes it challenging for OC source apportionment beyond separating it into primary and secondary OC. Attempts have been made to apportion OC into different sources based on molecular makers. For example, by using molecular maker-based chemical mass balance modeling (CMB-MM), Zheng et al. (2006) attributed OC into various primary emission sources such as wood combustion and gasoline engine exhaust. However, limited by the number of molecular markers included in the model, the CMBMM method is insufficient to resolve SOC and often results in high percentages of unexplained OC (Zheng et al., 2002). Also, filter samples collected on a daily basis have been used in most previous studies, which limits the temporal resolution and could introduce uncertainty due to filter sampling artifacts. The Aerodyne Aerosol Mass Spectrometer (AMS) has been widely used to characterize the chemical composition of submicron non-refractory species with high temporal resolution (Canagaratna et al., 2007; Jayne et al., 2000). Budisulistiorini et al. (2013) deployed an Aerosol Chemical Speciation Monitor (ACSM) (Ng et al., 2011) at the SEARCH Jefferson Street (JST) site in downtown Atlanta, GA. Various OA sources were identified by factor analysis in Budisulistiorini et al. (2013), including one source related to isoprene oxidation. However, due to the lower resolving power of ACSM, positive matrix factorization (PMF) analysis on ACSM data has difficulty in separating different primary sources such as cooking and vehicle emission, which have similar mass spectra (Crippa et al., 2014; Mohr et al., 2009). In addition, measurements at both rural and urban sites are needed in order to investigate the spatial distribution of aerosol and various OA subtypes.

Organic nitrates are important atmospheric species as their fate could affect the nitrogen cycle and ozone production (Perring et al., 2013; Mao et al., 2012). Organic nitrates, which are primarily formed from VOCs oxidation by nitrate radicals or by ozone and hydroxyl radical in the presence of $\mathrm{NO}_{x}$, have been shown to be an important component of organic aerosol. For example, Rollins et al. (2012) observed that organic nitrates contribute about $27-40 \%$ 


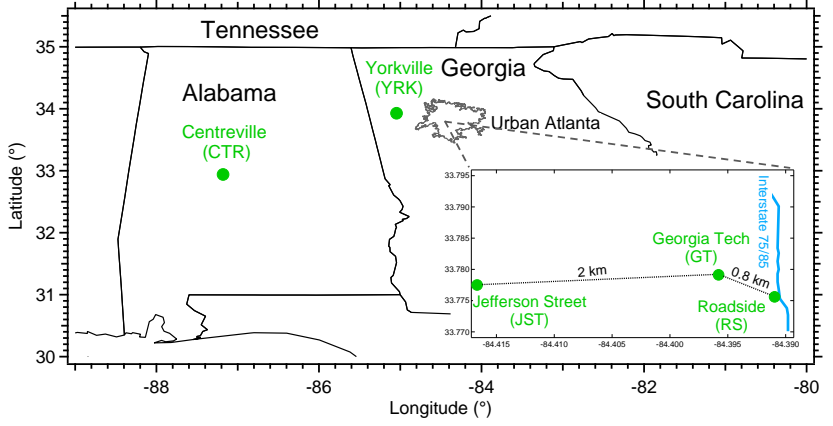

Figure 1. Sampling sites for SCAPE and SOAS studies. The gray circled region represents urban Atlanta.

to the OA growth at night in Bakersfield, CA, by using a thermal-dissociation laser-induced fluorescence technique ((TD-LIF)) (Day et al., 2002). Multiple approaches have also been proposed to estimate organic nitrates from indirect measurements. For example, Farmer et al. (2010) proposed that the concentration of the nitrate functionality (i.e., $-\mathrm{ONO}_{2}$ ) in organic nitrates could be estimated based on the nitrate functionality fragmentation pattern in the AMS or the differences between AMS and ion-chromatography (IC) measurements.

In this study, we performed measurements by a suite of instrumentation in multiple sites in the greater Atlanta, GA, area and Centreville, AL, with a focus on a high-resolution time-of-flight aerosol mass spectrometer (HR-ToF-AMS). Positive matrix factorization analysis is performed on HRToF-AMS data to identify distinct OA sources. The contribution of organic nitrates to total OA is estimated by different methods based on HR-ToF-AMS measurements. Measurements were performed in both rural and urban sites to investigate the spatial distribution of aerosol in the southeastern USA. In addition, measurements spanning over 1 year allow us to evaluate the seasonal variation of aerosol composition. These results are supported by long-term measurements from the SEARCH network and provide further insights into interpreting historic measurements.

\section{Method}

Measurements were conducted at the following sites as part of two field campaigns.

\subsection{Southern Oxidant and Aerosol Study (SOAS)}

SOAS (http://soas2013.rutgers.edu/) is a collaborative field campaign that took place from 01 June to 15 July 2013. The sampling site $\left(32.94^{\circ} \mathrm{N}, 87.18^{\circ} \mathrm{W}\right)$ is a SEARCH network site near Centreville, in rural Alabama, as shown in Fig. 1. The site is located in a forested area away from large urban cities $(55 \mathrm{~km} \mathrm{SE}$ of Tuscaloosa and $84 \mathrm{~km} \mathrm{SW}$ of Birmingham, AL). Detailed meteorological conditions of the sampling site can be found in Hidy et al. (2014). In brief, the sampling period was characterized by high relative humidity ( $>50 \%$ all the time), warm temperatures (daily maximum $28.6^{\circ} \mathrm{C}$ at 15:00 local time), and light winds (Xu et al., 2015).

\subsection{Southeastern Center for Air Pollution and Epidemiology study (SCAPE)}

This extensive field study was part of SCAPE (http://scape. gatech.edu/), which is an EPA-funded joint research center between Georgia Institute of Technology (GT) and Emory University, focusing on the study of air quality and the health effects of air pollutants (Verma et al., 2014; Winquist et al., 2014; Russell et al., 2014). Four sampling sites in both rural and urban areas are selected, as shown in Fig. 1. Detailed description of each sampling site can be found in Verma et al. (2014) and Hansen et al. (2003). A brief description follows.

- Roadside (RS) site is on the GT campus and adjacent (within $5 \mathrm{~m}$ ) to the Interstate 75/85 (8 lanes each direction). According to the Georgia Department of Transportation, about $95 \%$ of the traffic fleet on the Interstate $75 / 85$ is light-duty gasoline vehicles.

- GT site is also on the GT campus but $840 \mathrm{~m}$ away from the roadside site. The GT site is located on the top floor of the Ford Environmental Science \& Technology Building, which is $30-40 \mathrm{~m}$ above ground.

- Jefferson Street (JST) site is a central SEARCH network site about $2 \mathrm{~km}$ west of the GT site. This site is situated in Atlanta's urban area and surrounded by a mixed residential and commercial neighborhood and is considered representative of urban Atlanta.

- Yorkville (YRK) site is the SEARCH rural pair to the JST site located approximately $80 \mathrm{~km}$ northwest of JST. This site is situated in a mixed forest-agricultural area and immediately surrounded by pastures for cattle grazing.

We outfitted a trailer with a large suite of instrumentation (described in Sect. 2.3) and conducted measurements from May 2012 to February 2013, with roughly 1 month at each site and repeated it in different seasons. The sampling periods are listed in Table 1.

While the trailer was rotated between multiple sites, we also deployed an Aerosol Chemical Speciation Monitor (described in Sect. 2.3.2) (Ng et al., 2011) at the GT site from May 2012 to February 2013. The paired and simultaneous measurements using an ACSM at the GT site and an HRToF-AMS (described in Sect. 2.3.1) rotating among four different sites allow for investigating spatial distributions of aerosol loading and composition in the greater Atlanta area. It is noted that from 20 July to 04 September 2012, both the HR-ToF-AMS and the ACSM were deployed at the GT site for instrument intercomparison. 
Table 1. Sampling sites and periods for the SCAPE and SOAS studies. Campaign average meteorological conditions, mixing ratios of gasphase species, and mass concentrations of black carbon and NR-PM 1 species for all data sets. Average \pm 1 standard deviation is reported.

\begin{tabular}{|c|c|c|c|c|c|c|c|c|}
\hline \multicolumn{2}{|c|}{ AMS sampling site } & Jefferson Street & Centreville & Yorkville & Georgia Tech & Jefferson Street & Yorkville & Roadside \\
\hline \multicolumn{2}{|c|}{ Sampling period } & $\begin{array}{l}10 \text { May- } \\
\text { 02 Jun } 2012\end{array}$ & $\begin{array}{c}\text { 01 Jun- } \\
15 \text { Jul } 2013\end{array}$ & $\begin{array}{c}26 \text { Jun- } \\
20 \mathrm{Jul} 2012\end{array}$ & $\begin{array}{c}20 \text { Jul- } \\
04 \text { Sep } 2012\end{array}$ & $\begin{array}{c}\text { 06 Nov- } \\
04 \text { Dec } 2012\end{array}$ & $\begin{array}{c}\text { 05 Dec 2012- } \\
10 \text { Jan } 2013\end{array}$ & $\begin{array}{c}26 \text { Jan- } \\
28 \text { Feb } 2013\end{array}$ \\
\hline \multicolumn{2}{|c|}{ Abbreviation } & JST_May & CTR_June & YRK_July & GT_Aug & JST_Nov & YRK_Dec & RS_Jan \\
\hline Met $^{\mathrm{a}}$ & $\begin{array}{l}T\left({ }^{\circ} \mathrm{C}\right)^{\mathrm{b}} \\
\mathrm{RH}(\%) \\
\mathrm{WS}\left(\mathrm{ms}^{-1}\right)\end{array}$ & $\begin{array}{c}23.0 \pm 4.3 \\
65.8 \pm 19.3 \\
1.6 \pm 1.1\end{array}$ & $\begin{array}{c}24.7 \pm 4.3 \\
82.9 \pm 15.3 \\
1.9 \pm 0.9\end{array}$ & $\begin{array}{c}26.9 \pm 4.5 \\
61.9 \pm 18.5 \\
2.3 \pm 1.1\end{array}$ & $\begin{array}{c}26.1 \pm 3.5 \\
71.2 \pm 17.2 \\
1.3 \pm 0.8\end{array}$ & $\begin{array}{c}11.3 \pm 5.0 \\
64.5 \pm 20.6 \\
1.3 \pm 0.9\end{array}$ & $\begin{array}{c}7.8 \pm 5.5 \\
74.2 \pm 20.1 \\
3.4 \pm 1.7\end{array}$ & $\begin{array}{c}8.1 \pm 4.8 \\
64.6 \pm 25.3 \\
2.1 \pm 1.4\end{array}$ \\
\hline Gas (ppb) & $\begin{array}{l}\mathrm{NO} \\
\mathrm{NO}_{2} \\
\mathrm{SO}_{2} \\
\mathrm{O}_{3}\end{array}$ & $\begin{array}{c}4.1 \pm 13.0 \\
10.3 \pm 10.3 \\
0.4 \pm 0.7 \\
39.0 \pm 21.9\end{array}$ & $\begin{array}{c}0.1 \pm 0.2 \\
0.6 \pm 0.6 \\
0.3 \pm 0.7 \\
26.4 \pm 12.4\end{array}$ & $\begin{array}{c}0.1 \pm 0.1 \\
1.1 \pm 0.8 \\
0.4 \pm 0.5 \\
41.1 \pm 17.0\end{array}$ & $\begin{array}{l}\text { N/A } \\
\text { N/A } \\
\text { N/A } \\
\text { N/A }\end{array}$ & $\begin{array}{c}32.1 \pm 60.2 \\
18.4 \pm 12.8 \\
1.2 \pm 1.7 \\
18.8 \pm 14.5\end{array}$ & $\begin{array}{c}0.3 \pm 0.8 \\
3.0 \pm 3.0 \\
0.6 \pm 1.1 \\
28.8 \pm 8.3\end{array}$ & $\begin{array}{l}\text { N/A } \\
\text { N/A } \\
\text { N/A } \\
\text { N/A }\end{array}$ \\
\hline $\mathrm{PM}_{2.5}\left(\mu \mathrm{g} \mathrm{m}^{-3}\right)$ & $\mathrm{BC}^{\mathrm{c}}$ & N/A & $0.2 \pm 0.2$ & N/A & $0.9 \pm 0.7$ & $0.9 \pm 1.0$ & $0.4 \pm 0.3$ & $1.3 \pm 1.0$ \\
\hline NR-PM $1\left(\mu \mathrm{g} \mathrm{m}^{-3}\right)$ & $\begin{array}{l}\mathrm{SO}_{4} \\
\mathrm{NO}_{3} \\
\mathrm{NH}_{4} \\
\mathrm{Chl} \\
\mathrm{Org}\end{array}$ & $\begin{aligned} 3.0 & \pm 1.5 \\
0.4 & \pm 0.3 \\
1.1 & \pm 0.5 \\
0.03 & \pm 0.03 \\
9.1 & \pm 4.3\end{aligned}$ & $\begin{aligned} 1.9 & \pm 1.4 \\
0.1 & \pm 0.1 \\
0.4 & \pm 0.3 \\
0.01 & \pm 0.01 \\
5.0 & \pm 4.0\end{aligned}$ & $\begin{array}{c}3.5 \pm 1.8 \\
0.3 \pm 0.2 \\
1.1 \pm 0.5 \\
0.03 \pm 0.03 \\
11.2 \pm 6.4\end{array}$ & $\begin{array}{c}4.0 \pm 2.1 \\
0.4 \pm 0.4 \\
1.2 \pm 0.6 \\
0.02 \pm 0.01 \\
9.6 \pm 4.4\end{array}$ & $\begin{aligned} & 1.7 \pm 0.9 \\
1.2 & \pm 1.1 \\
0.9 & \pm 0.6 \\
0.06 & \pm 0.07 \\
7.9 & \pm 5.1\end{aligned}$ & $\begin{array}{c}1.4 \pm 1.0 \\
0.8 \pm 0.8 \\
0.6 \pm 0.5 \\
0.04 \pm 0.07 \\
3.2 \pm 2.3\end{array}$ & $\begin{array}{c}1.6 \pm 1.2 \\
1.4 \pm 1.3 \\
0.9 \pm 0.6 \\
0.06 \pm 0.11 \\
4.7 \pm 3.6\end{array}$ \\
\hline
\end{tabular}

\subsection{Instrumentation}

\subsubsection{High Resolution Time-of-Flight Aerosol Mass Spectrometer}

An HR-ToF-AMS was rotated among different sites in this study to characterize the composition of ambient submicron non-refractory particulate matter $\left(\mathrm{NR}-\mathrm{PM}_{1}\right)$. A detailed description of the HR-ToF-AMS can be found in the literature (Canagaratna et al., 2007; DeCarlo et al., 2006). In brief, the HR-ToF-AMS focuses ambient particles with vacuum aerodynamic diameter smaller than $1 \mu \mathrm{m}$ into a narrow beam via an aerodynamic lens. The submicron particles are then impacted on a hot tungsten surface $\left(\sim 600^{\circ} \mathrm{C}\right)$, where nonrefractory species are flash vaporized. The resultant vapors are ionized using $70 \mathrm{eV}$ electron impact ionization and analyzed by a time-of-flight mass spectrometer. During sampling, a $\mathrm{PM}_{1}$ cyclone was used to remove coarse particles. A nafion dryer was placed upstream of the HR-ToF-AMS to dry the particles (relative humidity $<20 \%$ ) in order to eliminate the potential influence of relative humidity on particle collection efficiency (CE) at the vaporizer (Matthew et al., 2008). Gas-phase interference was eliminated by subtracting the signals when the HR-ToF-AMS sampled through a HEPA filter, which was performed regularly on a daily basis at different times of the day. Ionization efficiency (IE) calibrations were performed with $300 \mathrm{~nm}$ ammonium nitrate (AN) particles on a weekly basis. The composition-dependent CE was applied to the data based on Middlebrook et al. (2012). We operated the HR-ToF-AMS in two ion optical modes (V and W) with different sensitivity and spectra resolution, but only
$\mathrm{V}$ mode data are reported in this study considering the low intensity of $\mathrm{W}$ mode data. The average sampling time was set at $2 \mathrm{~min}$. The data analysis was performed using the standard AMS analysis toolkits SQUIRREL v1.53 and PIKA v1.12 in Igor Pro 6.34 (WaveMetrics Inc.). Default relative ionization efficiency (RIE) values were used for the HR-ToF-AMS data. Elemental ratios, such as atomic oxygen-to-carbon ratio $(\mathrm{O}: \mathrm{C})$, hydrogen-to-carbon ratio $(\mathrm{H}: \mathrm{C})$, and organic massto-organic carbon ratio (OM: $\mathrm{OC})$, are determined by following the latest procedures recommended by Canagaratna et al. (2015). Canagaratna et al. (2015) improved the estimation from Aiken et al. (2008), which has been widely used in the literature to estimate elemental ratios, by including composition-dependent correction factors. Caution is required when comparing the elemental ratios in this study with values reported in the literature, which typically used the Aiken estimation. Nitrate signals $\left(\mathrm{NO}^{+}\right.$and $\left.\mathrm{NO}_{2}^{+}\right)$and sulfate signals $\left(\mathrm{SO}^{+}, \mathrm{SO}_{2}^{+}\right.$, etc.) are not included in the elemental ratio calculations. Oxidation state (OS) is calculated as $2 \times \mathrm{O}: \mathrm{C}-\mathrm{H}: \mathrm{C}$ (Kroll et al., 2011).

\subsubsection{Aerosol Chemical Speciation Monitor}

An ACSM was stationary at the GT site from 10 May 2012 to 28 February 2013. Similar to the HR-ToF-AMS, the ACSM also provides continuous quantitative measurements of NR$\mathrm{PM}_{1}$ (Ng et al., 2011). The mass resolving power of ACSM $(\sim 200)$ is lower than that of the HR-ToF-AMS $(\sim 2000$ in $\mathrm{V}$ mode) due to use of a low-cost residual gas analyzer quadrupole mass spectrometer in ACSM (Ng et al., 2011). In addition, the time resolution of ACSM $(\sim 30 \mathrm{~min})$ is longer 
than that of HR-ToF-AMS ( $\sim 2$ min $)$. The response factor of the ACSM was also determined by using $300 \mathrm{~nm}$ ammonium nitrate particles ( $\mathrm{Ng}$ et al., 2011). The RIE values used for organics, nitrate, and chloride are $1.4,1.1$, and 1.3 , respectively. RIE values of 4.18 and 0.59 were used for ammonium and sulfate, which were determined from IE calibrations by using ammonium nitrate and ammonium sulfate particles.

\subsubsection{Co-located instruments}

In addition to the HR-ToF-AMS, we deployed various instruments in the trailer while performing measurements at multiple sites (Verma et al., 2014). Instruments of interest to this study include a PILS-LWCC-TOC system (Particle Into Liquid Sampler - Liquid Waveguide Capillary Cell - Total Organic Carbon analyzer), a seven-wavelength Aethalometer and a multi-angle absorption photometer (MAAP). The PILS-LWCC-TOC system continuously (i.e., 15 min resolution) measured the light absorption spectra of water-soluble organic components. The detailed working principle of the PILS-LWCC-TOC system can be found in Hecobian et al. (2010). In brief, water-soluble species are first dissolved in water in a PILS (Weber et al., 2001). The liquid sample from the PILS is then injected into a Liquid Waveguide Capillary Cell, where the absorption spectra are collected over wavelengths of 200 to $800 \mathrm{~nm}$. The average light absorption between 360 and $370 \mathrm{~nm}$ is used as a measure of brown carbon light absorption. Black carbon concentration was measured by either a seven-wavelength Aethalometer or a MAAP. For the Aethalometer, measurements at $660 \mathrm{~nm}$ were chosen to represent the black carbon concentration, because $660 \mathrm{~nm}$ is closest to the wavelength utilized by the MAAP. The measured data were corrected for loading effects (Virkkula et al., 2007). The temporal resolutions are 2 and $1 \mathrm{~min}$ for Aethalometer and MAAP, respectively.

At the JST and YRK sites, a suite of instruments was operated by the SEARCH network. Detailed descriptions about the collocated instruments can be found in Hansen et al. (2003) and Edgerton et al. (2005). In brief, $\mathrm{O}_{3}$ concentration was measured by a UV-absorption analyzer with a temporal resolution of $1 \mathrm{~min}$. $\mathrm{NO}$ and $\mathrm{NO}_{x}$ were measured by a chemiluminescence analyzer (1min temporal resolution), where the $\mathrm{NO}_{2}$ concentration was calculated by subtracting NO from the total $\mathrm{NO}_{x} . \mathrm{PM}_{2.5}$ sulfate and OC were continuously measured by a Fe-reduction/UV-fluorescence analyzer and an oxidative combustion (R\&P 5400) analyzer, respectively. The temporal resolution is 5 and $60 \mathrm{~min}$ for $\mathrm{PM}_{2.5}$ sulfate and $\mathrm{OC}$, respectively. Meteorological conditions such as temperature, relative humidity $(\mathrm{RH})$, solar radiation, and wind speed were also recorded.

\subsection{Positive Matrix Factorization analysis}

PMF is a mathematical technique to solve bilinear unmixing problems (Paatero, 1997; Paatero and Tapper, 1994). PMF analysis has been widely applied in the aerosol community for source apportionment (Ulbrich et al., 2009; Jimenez et al., 2009; Zhang et al., 2010; Lanz et al., 2007; $\mathrm{Ng}$ et al., 2010; Beddows et al., 2015; Jaeckels et al., 2007; Visser et al., 2015). For the data measured by AMS, PMF analysis represents the observed data matrix as a linear combination of various factors with constant mass spectra but varying concentrations across the data set (Ulbrich et al., 2009; Zhang et al., 2011). To determine the sources of organic aerosol, PMF analysis was performed on the high-resolution organic mass spectra $(m / z, 12-200)$ obtained by the HR-ToF-AMS for each sampling data set. We generated the organic data matrix and error matrix from PIKA v1.12 and pretreated the error matrix by using PMF Evaluation Toolkit (PET) software following the procedure described in Ulbrich et al. (2009). Variables (i.e., $m / z$ ) with a signal-to-noise ratio less than 0.2 were removed and variables with a signal-tonoise ratio ranging between 0.2 and 2 were downweighted by a factor of 2 . We downweighted the errors of $\mathrm{O}^{+}, \mathrm{HO}^{+}$, $\mathrm{H}_{2} \mathrm{O}^{+}$, and $\mathrm{CO}^{+}$, which are related to $\mathrm{CO}_{2}^{+}$signal, to avoid excessive weighting of $\mathrm{CO}_{2}^{+}$. In addition, for four data sets (JST_May, CTR_June, YRK_July, and GT_Aug), the error of $\mathrm{CHO}^{+}$was downweighted by a factor of 4 . This is because PIKA v1.12 appears to underestimate $\mathrm{CHO}^{+}$error, which is possibly caused by the overlap of the $\mathrm{CHO}^{+}(\mathrm{m} / z$ 29.0027) ion with its adjacent $\mathrm{N}_{2}$ isotope ion (j15NN, $m / z$ 29.0032). For the other three data sets (JST_Nov, YRK_Dec, and RS_Jan), $\mathrm{CHO}^{+}$was not included in the PMF analysis due to its occasional negative signal, which is likely caused by a low $\mathrm{CHO}^{+}$signal in winter. At times, the $\mathrm{CHO}^{+}$concentration was near the detection limit, so a shift in threshold might cause the $\mathrm{CHO}^{+}$signal to be treated as noise. PMF solutions were carefully evaluated according to the procedure outlined in Zhang et al. (2011). For each data set, the optimal solution was determined after examining the residuals of PMF fits, interpretability of factor's diurnal trend, factor correlation with external tracers, and characteristic signatures of factor mass spectrum. The rotational ambiguity of solutions was examined by changing the parameter FPEAK and the robustness of solutions were evaluated by starting PMF with different initial conditions (parameter SEED). The key diagnostic plots for all data sets are shown in Fig. S1 in the Supplement. An FPEAK value of 0 is used for all data sets in our PMF analysis on organic mass spectra, because the use of FPEAK values that are different from 0 does not improve the correlations between PMF factors with external tracers. 


\subsection{Estimation of organic nitrates contribution to ambient $\mathrm{OA}$}

As direct measurements of organic nitrates are not available, we estimate the concentration of particle-phase organic nitrates at each site based on HR-ToF-AMS measurements in this study. It is important to note that total nitrates measured by the HR-ToF-AMS (denoted as $\mathrm{NO}_{3 \text {, meas }}$ ) is the nitrate functionality $\left(-\mathrm{ONO}_{2}\right)$, which could arise from both inorganic and organic nitrates. Here, we apply two independent methods of separating the measured total nitrates into nitrate functionality from inorganic and organic nitrates. In the following discussion, we use the subscripts meas, inorg, and org to denote nitrate functionality $\left(-\mathrm{ONO}_{2}\right)$ or fragments $\left(\mathrm{NO}^{+}\right.$ and $\mathrm{NO}_{2}^{+}$) from total nitrates (measured), inorganic nitrates (calculated), and organic nitrates (calculated), respectively.

The first method is based on the $\mathrm{NO}^{+} / \mathrm{NO}_{2}^{+}$ratio (denoted as $\mathrm{NO}_{x}^{+}$ratio method for discussions hereafter) in the AMS mass spectra (Farmer et al., 2010). Due to the extensive fragmentation caused by $70 \mathrm{eV}$ electron ionization in the HR-ToF-AMS, the nitrate functionality $\left(-\mathrm{ONO}_{2}\right)$ fragments to produce $\mathrm{NO}^{+}$and $\mathrm{NO}_{2}^{+}$ions. Previous laboratory studies have shown that the $\mathrm{NO}_{x}^{+}$ratio in the aerosol mass spectrum is substantially higher for organic nitrates than ammonium nitrate (Bruns et al., 2010; Fry et al., 2009; Sato et al., 2010; Farmer et al., 2010; Boyd et al., 2015), which is the major source of $\mathrm{PM}_{1}$ inorganic nitrates in the southeast USA detectable by the AMS (Guo et al., 2015; Allan et al., 2004). For example, while the $\mathrm{NO}_{x}^{+}$ratio is about 2.4 for ammonium nitrate, the ratio ranges from 5 to 10 for SOA derived from isoprene $+\mathrm{NO}_{3}^{*}$ and $\beta$-pinene $+\mathrm{NO}_{3}^{*}$ reactions, respectively (Bruns et al., 2010; Boyd et al., 2015). In addition to organic nitrates produced from biogenic VOC oxidation, Sato et al. (2010) showed that the $\mathrm{NO}_{x}^{+}$ratio of organic nitrates from the photooxidation of aromatic hydrocarbons is also clearly higher than that of ammonium nitrate (3.85.8 vs. 1.1-2.8). Based on the differences in $\mathrm{NO}_{x}^{+}$ratio between organic and inorganic nitrates, Farmer et al. (2010) proposed that the concentrations of $\mathrm{NO}_{\text {org }}$ and $\mathrm{NO}_{2, \text { org }}$ can be estimated from $\mathrm{NO}_{\text {meas }}$ and $\mathrm{NO}_{2}$,meas by Eqs. (1) and (2).

$$
\begin{aligned}
\mathrm{NO}_{2, \text { org }} & =\frac{\mathrm{NO}_{2, \text { meas }} \times\left(R_{\text {meas }}-R_{\mathrm{AN}}\right)}{R_{\mathrm{ON}}-R_{\mathrm{AN}}} \\
\mathrm{NO}_{\text {org }} & =R_{\mathrm{ON}} \times \mathrm{NO}_{2, \text { org }}
\end{aligned}
$$

$R_{\text {meas }}$ is the $\mathrm{NO}_{x}^{+}$ratio from observation. $R_{\mathrm{AN}}$ is the $\mathrm{NO}_{x}^{+}$ ratio for pure AN, which has been reported to depend on instrument performance and vary between different instruments (Farmer et al., 2010; Rollins et al., 2010). In this study, we determine the $R_{\mathrm{AN}}$ of each data set from ionization efficiency (IE) calibrations using $300 \mathrm{~nm}$ ammonium nitrate particles. We find that $R_{\mathrm{AN}}$ varies between 1.73 and 2.93 (Table 2), which is within the range (1.1-3.5) reported in the literature (Sato et al., 2010; Farmer et al., 2010; Sun et al., 2012b; Fry et al., 2013). $R_{\mathrm{ON}}$ is the $\mathrm{NO}_{x}^{+}$ratio for or- ganic nitrates. Similar to $R_{\mathrm{AN}}, R_{\mathrm{ON}}$ also varies between instruments (Boyd et al., 2015; Bruns et al., 2010; Fry et al., $2009)$. Thus, the $R_{\mathrm{ON}}$ values reported in the literature cannot be directly applied in our data sets. In order to circumvent this issue, Fry et al. (2013) assumed that the $R_{\mathrm{ON}} / R_{\mathrm{AN}}$ value is instrument independent. The authors further obtained $R_{\mathrm{ON}}$ by multiplying $R_{\mathrm{AN}}$ determined from in-field IE calibrations with $R_{\mathrm{ON}} / R_{\mathrm{AN}}$ determined from six organic nitrate standards (average value $=2.25$ ). However, the reported $R_{\mathrm{ON}} / R_{\mathrm{AN}}$ values in the literature vary for different organic nitrates. For example, while the average $R_{\mathrm{ON}} / R_{\mathrm{AN}}$ value is 2.25 for the organic nitrate standards in Farmer et al. (2010), the $R_{\mathrm{ON}} / R_{\mathrm{AN}}$ ranges from 3.70 to 4.17 for organic nitrates produced from $\beta$-pinene oxidation by nitrate radicals (Boyd et al., 2015; Bruns et al., 2010; Fry et al., 2009). Considering the large variations in $R_{\mathrm{ON}} / R_{\mathrm{AN}}$ values and unknown contributions from different organic nitrates, we apply the $\mathrm{NO}_{x}^{+}$ratio method to obtain an estimation range by using extreme $R_{\mathrm{ON}}$ values. We select organic nitrates formed from isoprene and $\beta$-pinene oxidation as representative because of their large abundance in the southeastern USA, potential to produce organic nitrates, and because they cover a wide range of $R_{\mathrm{ON}} / R_{\mathrm{AN}}$ values (i.e., 2.08 for isoprene and 3.704.17 for $\beta$-pinene) (Boyd et al., 2015; Bruns et al., 2010; Fry et al., 2009). The organic nitrates derived from other biogenic VOCs (i.e., $\alpha$-pinene, limonene, 3 -carene) are not considered due to either their lower ambient concentrations in the southeastern USA or lower organic nitrate yields compared to isoprene and $\beta$-pinene (Xu et al., 2015). Though the photooxidation of aromatic VOCs could also produce organic nitrates, their $R_{\mathrm{ON}} / R_{\mathrm{AN}}$ ratio is close to that of isoprene organic nitrates (Sato et al., 2010). Multiplying the average $R_{\text {AN }}$ (i.e., $2.28 \pm 0.40)$ of all data sets in this study by the average $R_{\mathrm{ON}} / R_{\mathrm{AN}}$ ratio of isoprene (i.e., 2.08) and $\beta$-pinene organic nitrates (i.e., $3.99 \pm 0.25$ ) in the literature (Boyd et al., 2015; Bruns et al., 2010; Fry et al., 2009) within 1 standard deviation, we selected 5 (i.e., $4.74 \pm 0.83$ ) and 10 (i.e., 9.10 \pm 1.69 ) as the lower and upper values of $R_{\mathrm{ON}}$. It is important to note that $R_{\mathrm{ON}}$ values of 5 and 10 likely correspond to upper and lower bounds of the $\mathrm{NO}_{3}$,org concentrations estimated by the $\mathrm{NO}_{x}^{+}$ratio method. The assumption that $R_{\mathrm{ON}} / R_{\mathrm{AN}}$ is instrument independent warrants further study.

The second method is based on PMF analysis (denoted as PMF method). In addition to PMF analysis on organic mass spectra (denoted as $\mathrm{PMF}_{\text {org }}$ ), we have also performed $\mathrm{PMF}$ analysis on organic mass spectra together with $\mathrm{NO}^{+}$ and $\mathrm{NO}_{2}^{+}$ions (denoted as $\mathrm{PMF}_{\text {org }+\mathrm{NO} 3}$ ). Such analysis could provide useful insights regarding the relative contributions of organic and inorganic nitrates. For instance, Sun et al. (2012b) and Hao et al. (2014) performed PMF analysis on merged mass spectra with both organic and inorganic signals from HR-ToF-AMS measurements. The authors showed that the $\mathrm{NO}^{+}$and $\mathrm{NO}_{2}^{+}$fragments are distributed among a nitrate inorganic aerosol (NIA) factor and other organic aerosol factors. 
Table 2. A summary of organic nitrate estimations from the $\mathrm{NO}_{x}^{+}$ratio method and the PMF method. $R_{\mathrm{AN}}$ represents the $\mathrm{NO}_{x}^{+}$ratio $\left(=\mathrm{NO}^{+} / \mathrm{NO}_{2}^{+}\right)$for pure ammonium nitrate $(\mathrm{AN})$. $R_{\text {meas }}$ represents the $\mathrm{NO}_{x}^{+}$ratio from observation. $\mathrm{NO}_{3}$, meas represents the total nitrate

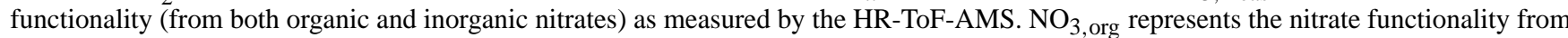
organic nitrates, which is estimated from the $\mathrm{NO}_{x}^{+}$ratio method. ON and OA represent organic nitrate and organic aerosol, respectively.

\begin{tabular}{|c|c|c|c|c|c|c|c|c|c|c|}
\hline \multirow[t]{2}{*}{ Site } & \multirow[t]{2}{*}{$R_{\mathrm{AN}}^{\mathrm{a}}$} & \multirow[t]{2}{*}{$R_{\text {meas }}$} & \multicolumn{2}{|c|}{$R$ with LO-OOA } & \multicolumn{2}{|c|}{$\begin{array}{l}\mathrm{NO}_{3, \text { org conc. }} \\
\quad\left(\mu \mathrm{g} \mathrm{m}^{-3}\right)^{\mathrm{d}}\end{array}$} & \multicolumn{2}{|c|}{$\mathrm{NO}_{3, \text { org }} / \mathrm{NO}_{3, \text { meas }}$} & \multicolumn{2}{|c|}{$\mathrm{ON} / \mathrm{OA}^{\mathrm{e}}$} \\
\hline & & & $\mathrm{NO}_{3, \text { meas }}$ & $\mathrm{NO}_{3, \text { org }}{ }^{\mathrm{b}}$ & lower & upper & lower & upper & lower & upper \\
\hline JST_May & 1.73 & 4.47 & 0.68 & 0.78 & 0.19 & 0.27 & 0.55 & 0.76 & 0.07 & 0.14 \\
\hline CTR_June ${ }^{\mathrm{c}}$ & 2.93 & 7.10 & 0.76 & 0.84 & 0.06 & 0.08 & 0.80 & 1.00 & 0.06 & 0.10 \\
\hline YRK_July & 2.24 & 5.45 & 0.66 & 0.83 & 0.18 & 0.28 & 0.63 & 1.00 & 0.05 & 0.12 \\
\hline GT_Aug & 2.26 & 6.17 & 0.56 & 0.70 & 0.21 & 0.33 & 0.64 & 0.99 & 0.07 & 0.16 \\
\hline JST_Nov & 1.95 & 3.12 & 0.14 & 0.63 & 0.23 & 0.25 & 0.19 & 0.21 & 0.09 & 0.15 \\
\hline YRK_Dec & 2.24 & 3.16 & 0.29 & 0.08 & 0.09 & 0.16 & 0.11 & 0.21 & 0.09 & 0.25 \\
\hline RS_Jan & 2.62 & 2.78 & 0.46 & -0.22 & 0.13 & 0.13 & 0.10 & 0.10 & 0.09 & 0.13 \\
\hline
\end{tabular}

${ }^{\text {a }} R_{\mathrm{AN}}$ is determined from IE calibrations at each site.

b The Pearson's correlation coefficient $(R)$ between LO-OOA and $\mathrm{NO}_{3 \text {, org }}$ are obtained by using $R_{\mathrm{ON}}=10$ in the $\mathrm{NO}_{x}^{+}$ratio method.

${ }^{\mathrm{c}}$ For CTR_June, only 24 June-15 July data are reported in order to compare with results from AMS-IC method where a PM $_{1}$ cyclone was used.

${ }^{\mathrm{d}}$ For CTR_June and YRK_July, the $\mathrm{NO}_{x}^{+}$ratio method with an $R_{\mathrm{ON}}=10$ and PMF method define the lower and upper bound for $\mathrm{NO}_{3}$,org, respectively; for JST_Nov, YRK_Dec, the PMF method and $\mathrm{NO}_{x}^{+}$ratio method with $R_{\mathrm{ON}}=10$ define the lower and upper bound, respectively; for RS_Jan, the PMF method defines both the lower and upper bound; for JST_May and GT_Aug, the $\mathrm{NO}_{x}^{+}$ratio method with $R_{\mathrm{ON}}=10$ and 5 defines the lower and upper bound, respectively.

$\mathrm{e}$ The lower and upper bounds correspond to an assumed molecular weight of organic nitrates of 200 and $300 \mathrm{~g} \mathrm{~mol}^{-1}$.

In this study, the selection of optimal solutions for PMF analysis on the merged mass spectra (i.e., $\mathrm{PMF}_{\mathrm{org}+\mathrm{NO} 3}$ ) is discussed in detail in the Supplement. In brief, in addition to examining the typical diagnostic plots (Fig. S3), the optimal solutions are selected by comparing the time series (Fig. S5), mass spectrum (Fig. S5), and mass concentration (Fig. S6) with results from $\mathrm{PMF}_{\mathrm{org}}$. After determining the optimal solution of $\mathrm{PMF}_{\mathrm{org}+\mathrm{NO}}$, the concentrations of "nitrate functionality from organic nitrates" (i.e., $\mathrm{NO}_{3, \text { org }}$ ) are calculated by summing up the nitrate signals (i.e., $\mathrm{NO}^{+}$and $\mathrm{NO}_{2}^{+}$) from all $\mathrm{OA}$ factors with the following equations:

$$
\begin{aligned}
{\left[\mathrm{NO}_{\text {org }}^{+}\right] } & =\sum\left([\mathrm{OA} \text { factor }]_{i} \times f \_\mathrm{NO}_{i}\right), \\
{\left[\mathrm{NO}_{2, \text { org }}^{+}\right] } & =\sum\left([\mathrm{OA} \text { factor }]_{i} \times f \_\mathrm{NO}_{2, i}\right),
\end{aligned}
$$

where [OA factor $]_{i}$ is the mass concentration of the $i$ th OA factor and $f \_\mathrm{NO}_{i}$ and $f \_\mathrm{NO}_{2, i}$ are the mass fraction of $\mathrm{NO}^{+}$ and $\mathrm{NO}_{2}^{+}$, respectively, in the $i$ th $\mathrm{OA}$ factor. For both the $\mathrm{NO}_{x}^{+}$ratio method and the PMF method, we calculate the concentration of $\mathrm{NO}_{3}$,inorg (i.e., nitrate functionality from inorganic nitrates) by subtracting $\mathrm{NO}_{3 \text {,org }}$ (i.e., nitrate functionality from organic nitrates) from $\mathrm{NO}_{3}$, meas (i.e., total measured nitrates).

\section{Results}

Table 1 lists the meteorology parameters (temperature, relative humidity, and wind speed), gas-phase concentrations of $\mathrm{NO}, \mathrm{NO}_{2}$, and $\mathrm{O}_{3}$, and aerosol composition of the seven data sets reported in this study. The average RH is above $60 \%$ for all the data sets, with little seasonal variation, which is con-
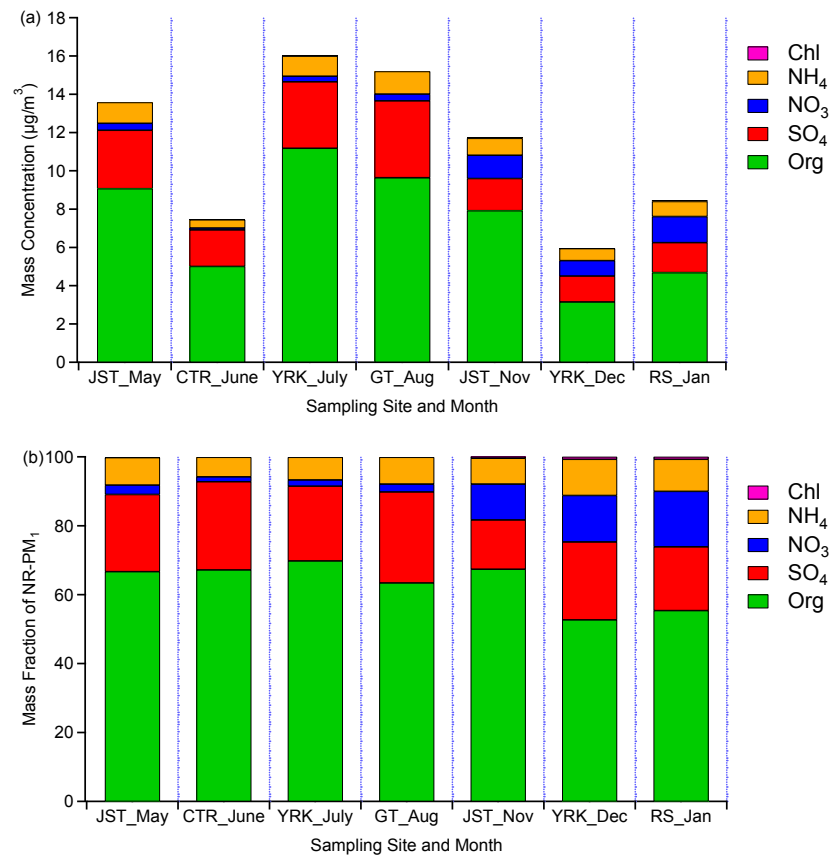

Figure 2. Mass concentrations (a) and mass fractions (b) of nonrefractory $\mathrm{PM}_{1}\left(\mathrm{NR}-\mathrm{PM}_{1}\right)$ species measured by HR-ToF-AMS.

sistent with previous observations (Ford and Heald, 2013). The high RH in the southeastern USA has direct impacts on particle water content and particle acidity. Recently, Guo et al. (2015) showed that particle water and acidity are mainly driven by the variability of $\mathrm{RH}$, although particle composition also plays a role. The average wind speed is relatively 
constant (1.3-3.4 m s${ }^{-1}$ ) throughout the year at all sites. $\mathrm{NO}_{x}$ ( $\mathrm{NO}$ and $\mathrm{NO}_{2}$ ) and black carbon (BC), which are tracers for anthropogenic emissions, are lower in the rural YRK site than the urban JST site. In YRK, the $\mathrm{NO}_{x}$ level is low (i.e., average concentration $<0.3 \mathrm{ppb}$ ) in all seasons. In contrast, at the urban JST site the $\mathrm{NO}_{x}$ level is elevated in winter compared to summer, indicating more anthropogenic emissions, or less dispersion, in winter at urban sites.

Figure 2 shows the composition of NR-PM 1 for all data sets. Organics are the dominant components, which account for more than $50 \%$ of NR-PM 1 mass at all sites throughout the year. Although dominant, the concentration of organic aerosol varies substantially among sites and seasons. The seasonal variation of OA mass concentration is small for the urban JST site $\left(9.1 \mu \mathrm{g} \mathrm{m}^{-3}\right.$ in May vs. $7.9 \mu \mathrm{g} \mathrm{m}^{-3}$ in November); however, the OA concentration is about 4 times higher in summer than winter for the rural YRK site $\left(11.2 \mu \mathrm{g} \mathrm{m}^{-3}\right.$ in July vs. $3.2 \mu \mathrm{g} \mathrm{m}^{-3}$ in December). The difference in seasonality of OA between urban and rural sites is likely due to the varying strength of different OA sources, which will be discussed in detail in Sect. 4.4.2. In terms of diurnal variation, the OA diurnal trend is relatively flat in summer and peaks at night in winter (Fig. 3). The diurnal variation of OA is largely influenced by the changes in planetary boundary layer height (BLH) and changes in contributions to total OA from various sources, which will be discussed in detail in Sect. 4.4.1. The campaign-average mass spectra of OA from all data sets are similar, as shown in Fig. S7. In order to assess the degree of oxidation of OA, average $f_{44}$ (the ratio of $\mathrm{m} / z 44$ to total OA signal) and $f_{43}$ (the ratio of $m / z, 43$ to total OA signal) of each data set are plotted in the triangular space as defined by $\mathrm{Ng}$ et al. (2010) in Fig. 4. The OA from all data sets locate in the middle part of the triangle, indicating they are moderately oxidized and have a similar degree of oxidation.

Following organics, sulfate $\left(\mathrm{SO}_{4}\right)$ has the second largest contribution to total NR-PM $\mathrm{PM}_{1}$ mass at all sites (Fig. 2). Average $\mathrm{SO}_{4}$ concentration varies between 3.0 and $4.0 \mu \mathrm{g} \mathrm{m}^{-3}$ at different sites in summer and decreases to $1.4-1.7 \mu \mathrm{g} \mathrm{m}^{-3}$ in winter. The $\mathrm{SO}_{4}$ concentration at most sites (except JST_Nov and RS_Jan) reaches a daily maximum in the afternoon (Fig. 3), which is likely caused by the strong photooxidation of $\mathrm{SO}_{2}$ or $\mathrm{SO}_{4}$ entrainment from aloft when the boundary layer height is the highest in the afternoon (Weber, 2003). In contrast to $\mathrm{SO}_{4}$, where the concentration is higher in summer, total nitrate concentration is elevated in winter. While the average concentration of total nitrates is $0.1-0.4 \mu \mathrm{g} \mathrm{m}^{-3}$

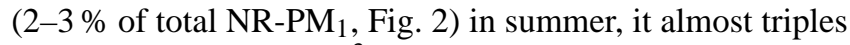
in winter $\left(0.8-1.4 \mu \mathrm{g} \mathrm{m}^{-3}\right)$ with elevated mass fraction in total NR-PM $1(10-16 \%)$. The reason for the seasonal variation of the total nitrates will be discussed in Sect. 4.2.2.
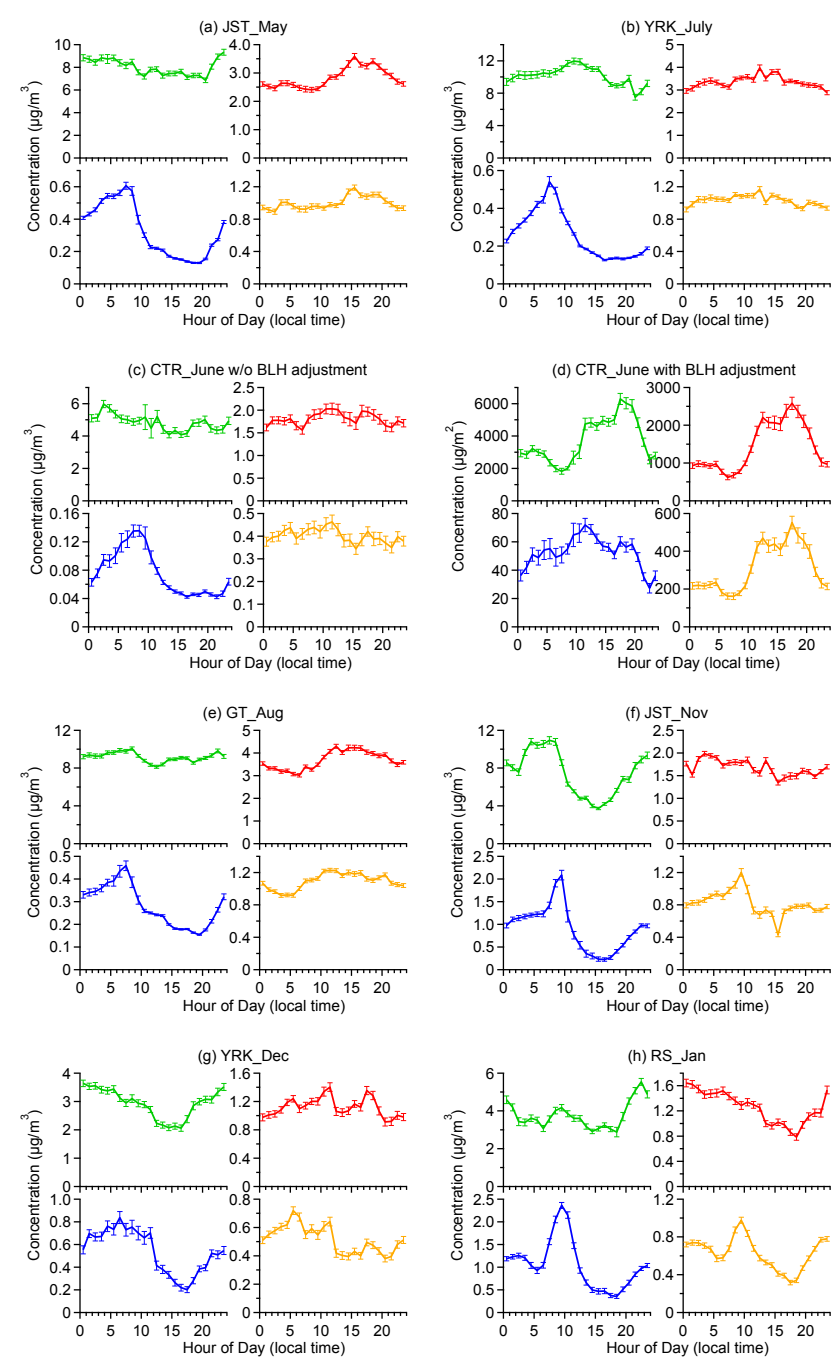

Figure 3. Diurnal profiles of non-refractory $\mathrm{PM}_{1}\left(\mathrm{NR}-\mathrm{PM}_{1}\right)$ species measured by HR-ToF-AMS. Panel (d) shows the diurnal profiles of NR-PM 1 species after multiplying by the boundary layer height for the Centreville (CTR) site. The solid lines indicate the median concentration and the error bars indicate the standard error.

\section{Discussion}

\subsection{OA source apportionment}

In this section, we focus on the OA source apportionment based on results from PMF analysis on organic mass spectra only (i.e., $\mathrm{PMF}_{\text {org }}$ ). We resolved various factors, including hydrocarbon-like OA (HOA), cooking OA (COA), biomass burning OA (BBOA), isoprene-derived OA (isoprene-OA), more-oxidized oxygenated OA (MO-OOA), and less-oxidized oxygenated OA (LO-OOA) at multiple sites in different seasons. Based on the inferred volatility from $\mathrm{O}: \mathrm{C}$ ratios, the two oxygenated $\mathrm{OA}$ factors (i.e., MOOOA and LO-OOA) are typically named as low-volatility OOA (higher O:C and lower volatility) and semi-volatile 

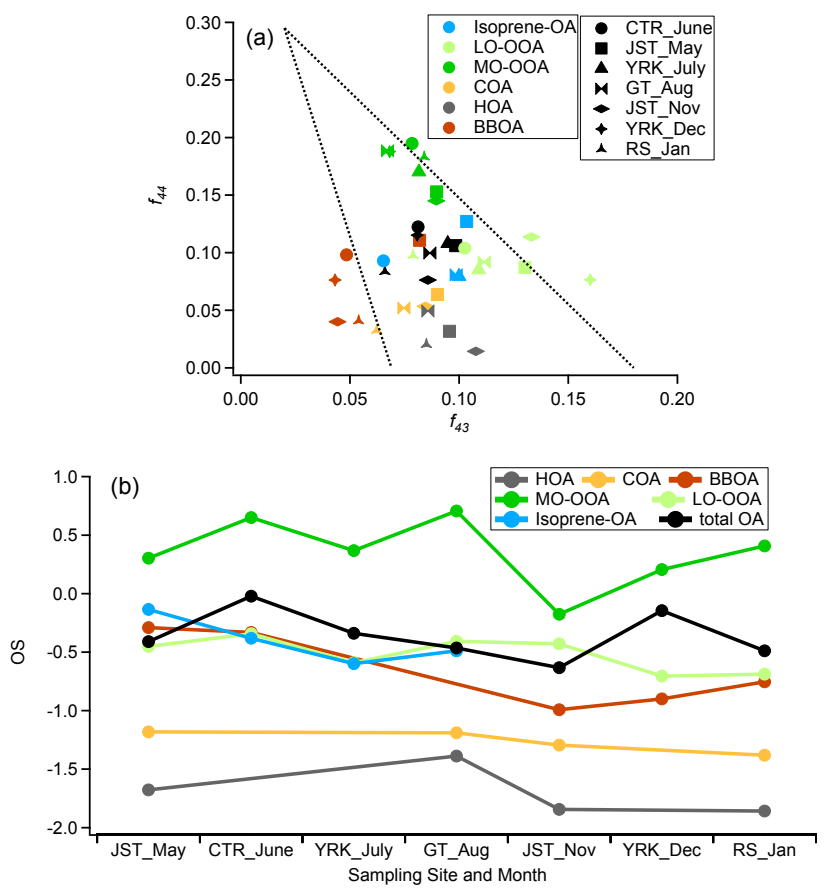

Figure 4. (a) $f_{44}$ vs. $f_{43}$ for total OA and OA factors resolved from $\mathrm{PMF}$ analysis on organic mass spectra only (i.e., $\mathrm{PMF}_{\text {org }}$ ). (b) The oxidation state of OA factors.

OOA (lower O:C and higher volatility) ( $\mathrm{Ng}$ et al., 2010; Jimenez et al., 2009). However, recent studies showed that $\mathrm{O}: \mathrm{C}$ ratios are not always well-correlated with aerosol volatility (Hildebrandt et al., 2010; Xu et al., 2014). Thus, in this study, we use the terms MO-OOA $(\mathrm{O}: \mathrm{C}$ ranges between 0.66 and 1.05 , with an average of 0.87 ) and LO-OOA $(\mathrm{O}: \mathrm{C}$ ranges between 0.44 and 0.62 with an average of 0.54 ) (Fig. S10). This terminology has been used in several previous studies (Setyan et al., 2012; Xu et al., 2015).

\subsubsection{HOA}

Hydrocarbon-like organic aerosol (HOA) is a surrogate of primary OA (POA) from vehicle emissions. Among all the OA factors, HOA is the least oxidized with oxidation state (OS) ranging from -1.86 to -1.39 (Fig. 4). The mass spectrum of HOA is characterized by hydrocarbon-like ions $\left(\mathrm{C}_{x} \mathrm{H}_{y}\right.$ family) as shown in Fig. $\mathrm{S} 2$, which is similar to the mass spectrum of freshly emitted traffic aerosol (Zhang et al., 2005). HOA is only identified at urban sites with evident morning and evening rush hour peaks (Fig. 5). HOA also shows good correlation with black carbon ( $R$ ranges from 0.70 to 0.83 ) (Fig. S2), further supporting the primary nature of this OA subtype.

For the sites where HOA is identified, HOA accounts for 9-15\% (daily average) of total OA (Fig. 6). Even for the RS site, which is within $5 \mathrm{~m}$ of the Interstate $75 / 85$, HOA only contributes $15 \%$ of total OA. Low contributions of HOA to total OA near highways have been observed in several prior studies (Sun et al., 2012a; DeWitt et al., 2015). For example, DeWitt et al. (2015) found that HOA only comprised $20 \%$ of total OA based on HR-ToF-AMS measurements in a high diesel environment (near a highway) in Paris, France. The small contribution of HOA could arise from the types of vehicles on road, the rapid dilution of vehicle emissions, or the high level of regional background OA. Firstly, roughly $95 \%$ of the traffic fleet on I75/85 is light-duty gasoline vehicles, according to Georgia Department of Transportation. Unlike diesel vehicles which have large emissions of POA and $\mathrm{BC}$, gasoline vehicles have a larger emission of VOCs (e.g., toluene and benzene) (Platt et al., 2013). Secondly, in addition to vehicle type, the evaporation of POA emitted from vehicles would further decrease its mass concentration. Robinson et al. (2007) showed that POA from vehicle emissions is indeed semi-volatile, which would evaporate substantially upon dilution from tailpipe to ambient conditions (a dilution ratio of $10^{3}$ to $10^{4}$ ). Thirdly, HOA tends to contribute a small fraction of OA because of the high level of regional background OA in the greater Atlanta area. For example, OOA factors (i.e., LO-OOA and MO-OOA) compromise $47-79 \%$ of OA as shown in Fig. 6. The effect of wind direction on HOA concentration is expected to be small considering the close proximity of the roadside sampling site to the highway.

\subsubsection{COA}

The mass spectrum of cooking organic aerosol (COA) is characterized by prominent signals at ions $\mathrm{C}_{3} \mathrm{H}_{5}^{+}(\mathrm{m} / z 41)$ and $\mathrm{C}_{4} \mathrm{H}_{7}^{+}(m / z$ 55) (Fig. S2), which could arise from the heating of seed oil (Allan et al., 2010). Another feature of COA is its unique diurnal trend. For three out of four data sets (except JST_Nov) where a COA factor is identified, the COA factor exhibits a small peak at lunch time and a large peak at dinner time (Fig. 5). The COA factor is identified in urban sites (JST, GT, and RS) throughout the year, with the average mass fraction varying from 12 to $20 \%$. A prior study by Zheng et al. (2002) estimated that meat cooking accounts for $5-12 \%$ of $\mathrm{PM}_{2.5}$ organic carbon in the southeastern USA by using a chemical mass balance receptor model. The range reported by Zheng et al. (2002) is similar to our study, considering the differences in sampling periods, particle size range, and estimation method. The COA factor has also been detected in many megacities around the world (Huang et al., 2010; Allan et al., 2010; Slowik et al., 2010; Mohr et al., 2012; Crippa et al., 2013), indicating cooking is an important OA source in megacities.

We note that the COA factor was not resolved in Budisulistiorini et al. (2013), in which the authors performed PMF analysis on the data collected by an ACSM at the JST site in 2011 summer and fall. The lack of a COA factor in the analysis by Budisulistiorini et al. (2013) could be a result of the lower resolution (unit mass resolution) of the ACSM 


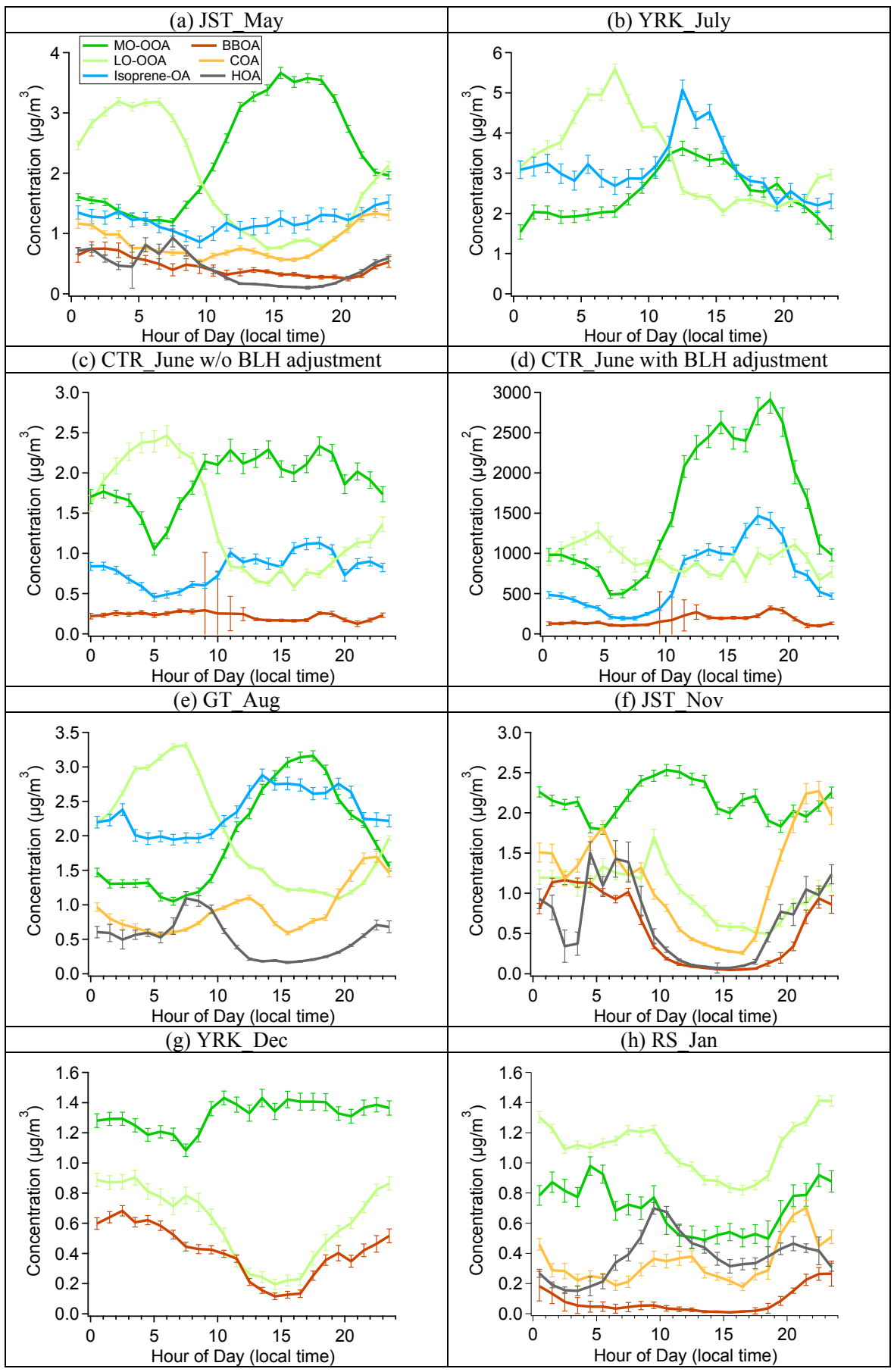

Figure 5. Diurnal profiles of OA factors resolved from PMF analysis on organic mass spectra. Panel (d) shows the diurnal profiles of OA factors after multiplying by the boundary layer height for the Centreville (CTR) site. The solid lines indicate the median concentration and the error bars indicate the standard error.

compared to HR-ToF-AMS. Previous studies have suggested that COA is not easily differentiated from HOA due to the similarity of their mass spectra in unit mass resolution data (Crippa et al., 2014; Mohr et al., 2009).

\subsubsection{Isoprene-OA}

The isoprene-OA factor is characterized by prominent signals at $\mathrm{C}_{4} \mathrm{H}_{5}^{+}(m / z 53)$ and $\mathrm{C}_{5} \mathrm{H}_{6} \mathrm{O}^{+}(m / z$ 82) in its mass spectrum (Fig. S2), which resembles that of isoprene SOA formed via isoprene epoxydiols (i.e., IEPOX) uptake in the 

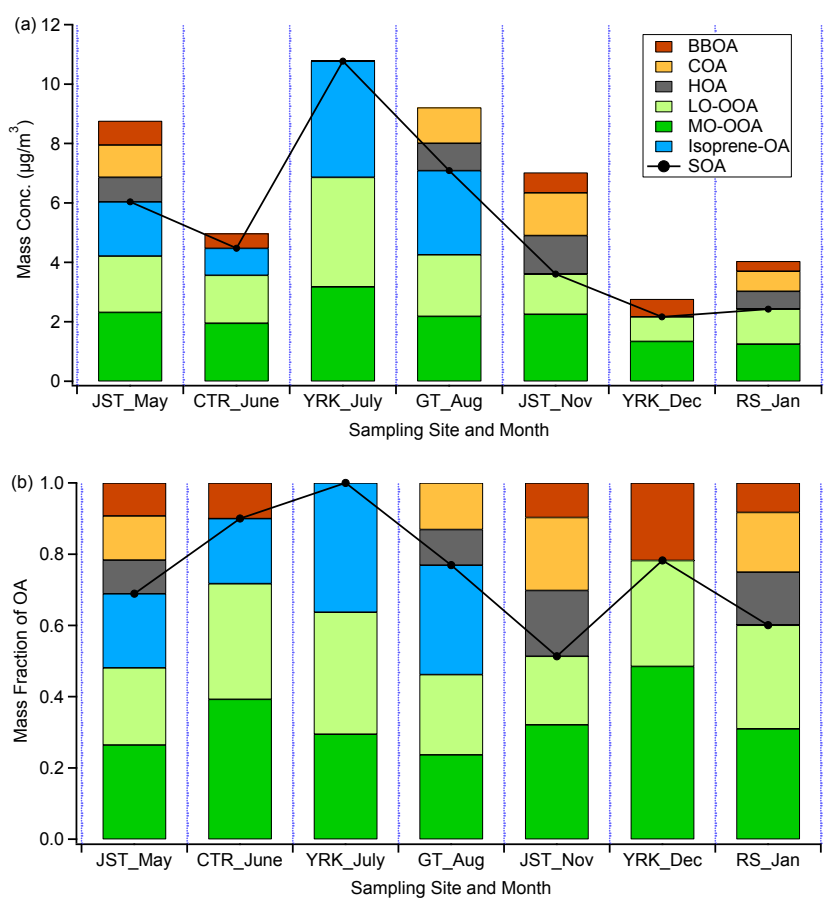

Figure 6. (a) Campaign-averaged mass concentrations of $\mathrm{OA}$ factors resolved from PMF analysis on organic mass spectra. (b) Campaign-averaged mass fractions of OA factors resolved from PMF analysis on organic mass spectra. SOA is the sum of isopreneOA, MO-OOA, and LO-OOA. POA is the sum of HOA, COA, and BBOA.

presence of hydrated sulfate in laboratory experiments (Lin et al., 2012; Budisulistiorini et al., 2013; Nguyen et al., 2014; Liu et al., 2015). For our data sets, isoprene-OA is only identified in warmer months (May-August) and accounts for $18-36 \%$ of total OA (Fig. 6). The seasonal variation of isoprene-OA factor is consistent with that of isoprene emissions, which are high in summer and nearly 0 in winter (Guenther et al., 2006). The identification of the isopreneOA factor is further supported by its correlation with methyltetrols, which are products formed from isoprene oxidation and likely via IEPOX uptake. For the Centreville data set, for which methyltetrols were continuously measured by a semi-volatile thermal desorption aerosol gas chromatograph (SV-TAG) (Isaacman et al., 2014), the correlation coefficient (Pearson's $R$ ) between the isoprene-OA factor and methyltetrols is found to be 0.68 (Xu et al., 2015).

The $f_{\mathrm{C} 5 \mathrm{H} 6 \mathrm{O}+}$ (the ratio of $\mathrm{C}_{5} \mathrm{H}_{6} \mathrm{O}^{+}$to total signal) in isoprene-OA factor, which is used as a characteristic marker for SOA formed via IEPOX uptake in the literature, ranges from 0.9 to $2.3 \%$ in this study. This range is similar to the values from other ambient data (Budisulistiorini et al., 2013; Chen et al., 2014; Hu et al., 2015; Robinson et al., 2011a; Slowik et al., 2011) but lower than that from laboratorygenerated fresh SOA from IEPOX uptake $3.6 \%$ from Liu et al., 2015). We note that the $f_{\mathrm{C} 5 \mathrm{H} 6 \mathrm{O}+}$ is higher at rural sites (1.9\% for YRK_July and $2.3 \%$ for CTR_June) than urban sites ( $0.9 \%$ for JST_May and $1.4 \%$ for GT_Aug). Similarly, Liu et al. (2015) observed that the mass spectrum of laboratory-generated SOA from IEPOX uptake has a stronger correlation with that of isoprene-OA factor from remote regions (Amazon and Borneo) than urban regions (Atlanta, USA). The identification of an isoprene-OA factor at urban sites in the current study has interesting implications. The compound IEPOX is thought to be an oxidation product of isoprene where the organic peroxy radicals react with hydroperoxy radicals (Paulot et al., 2009). In urban areas, one would expect the majority of organic peroxy radicals to react with $\mathrm{NO}_{x}$, considering the relatively high $\mathrm{NO}_{x}$ level ( $\sim 15.4$ ppb for JST_May in Table 1). However, a recent laboratory study by Jacobs et al. (2014) found that the oxidation of isoprene-derived hydroxynitrates in the presence of $\mathrm{NO}_{x}$ could also produce IEPOX. Thus, isoprene-OA observed in urban sites could be locally produced. Another possible source for isoprene-OA at urban sites is advection from rural sites. This could explain the lower $f_{\mathrm{C} 5 \mathrm{H} 6 \mathrm{O}+}$ in the isopreneOA factor in urban sites, because the compounds which give rise to the $\mathrm{C}_{5} \mathrm{H}_{6} \mathrm{O}^{+}$signal can be further oxidized during transport. However, the lifetime of the isoprene-OA factor and the changes in its mass spectral features with chemical aging are largely uncertain. The contribution of advection is probably small as it is unlikely that advection would result in a consistent diurnal profile of isoprene-OA, which reaches a daily maximum in the afternoon observed not only in this study (Fig. 5) but also in other regions, such as the Amazon (Chen et al., 2014) and Borneo forests (Janssen et al., 2013; Robinson et al., 2011a). In addition, Robinson et al. (2011a) observed the isoprene-OA factor in data obtained from afternoon flights but not in morning flights through airborne measurements in the Borneo forest, implying that the isoprene-OA formation is rapid and local. Another possibility for the lower $f_{\mathrm{C} 5 \mathrm{H} 6 \mathrm{O}+}$ at the urban sites is that isopreneOA factor from the urban sites may contain isoprene SOA produced via other pathways in addition to the IEPOX uptake pathway. Isoprene SOA formed via $\mathrm{RO}_{2}+\mathrm{NO}$ pathway only has a negligible signal at $\mathrm{C}_{5} \mathrm{H}_{6} \mathrm{O}^{+}$(Kroll et al., 2006; $\mathrm{Xu}$ et al., 2014), so that the mixing of isoprene SOA via different pathways may lower the $f_{\mathrm{C} 5 \mathrm{H} 6 \mathrm{O}+}$ in the isoprene-OA factor. Moreover, seasonality may also have an influence on the lower $f_{\mathrm{C} 5 \mathrm{H} 6 \mathrm{O}+}$ at the urban sites since the sampling periods at the urban sites are May and August, when the isoprene concentration is relatively lower than that during the sampling periods at the rural sites (i.e., June and July).

For all the sites where an isoprene-OA factor is resolved, the isoprene-OA factor is found to be well-correlated with sulfate ( $R$ ranging from 0.73 to 0.88 , Fig. S2). Xu et al. (2015) showed that the formation of isoprene-OA in the southeastern USA is largely controlled by the abundance of sulfate instead of the particle water content and/or particle acidity. While many prior laboratory studies show that particle acidity plays an important role in IEPOX uptake (Gaston 
et al., 2014; Surratt et al., 2007), results from ambient observations suggest that particle acidity is critical but not the limiting factor in isoprene-OA formation in the southeastern USA, which is likely due to the consistently high particle acidity in the southeastern USA (Guo et al., 2015; Xu et al., 2015). Guo et al. (2015) showed that the daily average particle $\mathrm{pH}$ throughout the southeastern USA ranges between 1.1 and 1.3 in summer time. In the afternoon, when the isoprene mixing ratio is highest and photochemistry is strongest, the particle $\mathrm{pH}$ is even lower, ranging between 0 and 0.75 due to lower particle water content. A recent chamber study (Gaston et al., 2014) showed that decreasing $\mathrm{pH}$ from 4.63 to 0.5 could greatly enhance IEPOX uptake by up to 150 times, but the enhancement is much weaker (a factor of 2 ) when furthering decreasing the $\mathrm{pH}$ from 0.5 to -0.27 , the range of which is relevant to ambient particle $\mathrm{pH}(0-0.75)$ in the summer afternoon in the southeastern USA (Guo et al., 2015). Similarly, another laboratory study also showed that the effect of particle acidity on IEPOX uptake is minor when the particle $\mathrm{pH}$ is low (Nguyen et al., 2014). By comparing the reactive uptake of IEPOX by using wet $\left(\mathrm{NH}_{4}\right)_{2} \mathrm{SO}_{4}$ seed $(\mathrm{pH} \sim 3.5)$ and wet $\mathrm{MgSO}_{4}+\mathrm{H}_{2} \mathrm{SO}_{4}$ mixture seed $(\mathrm{pH} \sim 0-1$ with large uncertainty), Nguyen et al. (2014) found that the reactive partitioning coefficient of IEPOX increases by only 1.5 times as $\mathrm{pH}$ decreases from 3.5 to $1\left(\mathrm{H}_{(\mathrm{aq})}^{+}\right.$increases by 2 or 3 orders of magnitude). Taken together, laboratory studies revealed that while increasing particle acidity could greatly enhance IEPOX uptake when $\mathrm{pH}$ is high, the sensitivity of IEPOX uptake to particle acidity is minor when $\mathrm{pH}$ is low. This is likely caused by isoprene-OA formation from IEPOX uptake being limited by nucleophiles instead of catalyst activity under low pH (Eddingsaas et al., 2010; Piletic et al., 2013), although a low $\mathrm{pH}$ is needed to enhance these reactions. We also note that the co-variation between particle acidity and sulfate is not considered in previous laboratory studies (Gaston et al., 2014; Surratt et al., 2007), so the effect of particle acidity could possibly be confounded with the effect of sulfate and warrants further investigation.

\subsubsection{BBOA}

The mass spectrum of biomass burning organic aerosol (BBOA) is characterized by prominent signals at ion $\mathrm{C}_{2} \mathrm{H}_{4} \mathrm{O}_{2}^{+}(m / z 60)$ and $\mathrm{C}_{3} \mathrm{H}_{5} \mathrm{O}_{2}^{+}(m / z$ 73). These two ions are largely produced by anhydrous sugars (e.g., levoglucosan and mannosan), which are formed from the breakdown of cellulose in biomass burning (Schneider et al., 2006). In addition, Heringa et al. (2011) showed that SOA produced during the aging of primary biomass burning emissions could contribute to these two ions. In this study, BBOA accounts for 9$22 \%$ of the OA (Fig. 6). The BBOA factor is mainly resolved in winter data sets, which is consistent with the EPA reported Georgia fire season in late winter (January-March) (Hidy et al., 2014) and the large enhancement in levoglucosan concentrations in winter compared to summer in Georgia (Zhang et al., 2010). BBOA is also identified in JST_May, which may arise from residential wood burning near JST site. The contribution of BBOA to total OA is slightly smaller than the values reported in other studies. Zhang et al. (2010) estimated that biomass burning accounted for $27 \%$ of $\mathrm{PM}_{2.5}$ mass in winter over the southeastern USA by performing PMF analysis on 10 species extracted from filter samples. The differences in biomass burning contribution to OA between this study and Zhang et al. (2010) are likely due to different estimation methods, sampling years (i.e., 2012-2013 vs. 2007), and sample size cut (i.e., $\mathrm{PM}_{1}$ vs. $\mathrm{PM}_{2.5}$ ).

It is important to note that the BBOA reported in this study likely only represents the relatively fresh OA from biomass burning. For example, laboratory studies revealed that the oxidation of levoglucosan is fast in both the gas and aqueous phases (Zhao et al., 2014; May et al., 2012; Hennigan et al., 2011). The fast oxidation of levoglucosan can result in the rapid decay of signals at $\mathrm{C}_{2} \mathrm{H}_{4} \mathrm{O}_{2}^{+}(m / z 60)$ and $\mathrm{C}_{3} \mathrm{H}_{5} \mathrm{O}_{2}^{+}$ $(m / z, 73)$, causing the mass spectrum of BBOA to lose its characteristic signature. In addition, laboratory studies by Hennigan et al. (2011) and Grieshop et al. (2009) showed that the mass spectrum of OA from biomass burning becomes increasingly similar to that of MO-OOA after photochemical aging. Ambient measurements in the eastern Mediterranean by Bougiatioti et al. (2014) showed evidence that BBOA could be rapidly converted to OOA in less than 1 day. Thus, aged OA from biomass burning could be apportioned to the MO-OOA factor.

Recent studies have revealed that OA from biomass burning is an important source for brown carbon (Washenfelder et al., 2015; Andreae and Gelencsér, 2006; Zhang et al., 2010; Lack et al., 2013), which has important impacts on climate (Feng et al., 2013; Liu et al., 2014). For four (out of five) data sets where BBOA is resolved by PMF analysis in this study, the Pearson's correlation coefficient $(R)$ between BBOA and brown carbon is greater than 0.69 , with the best correlation observed at JST_Nov $(R=0.90)$ (Fig. 7). The correlation coefficient between BBOA and brown carbon is only 0.47 for YRK_Dec, which is likely caused by other brown carbon sources at the YRK site. This hypothesis is supported by summer measurements at YRK. In YRK_July, we observed a large abundance of brown carbon, which reached a daily maximum at around 14:00 (Fig. S8); however, a BBOA factor is not resolved for YRK_July, indicating that brown carbon, in this case, could arise from sources other than biomass burning. Hecobian et al. (2010) suggested that SOA from aqueous phase reactions may be an important source for brown carbon in summer based on analysis of $\sim 900$ filters collected in 2007 in the southeastern USA. A recent laboratory study showed that SOA from IEPOX reactive uptake could be light-absorbing and potentially an important source for brown carbon (Lin et al., 2014). However, isoprene-OA factor, which is related to the IEPOX uptake pathway studied in Lin et al. (2014), only shows weak correlation ( $R$ ranges from 0.22 to 0.50 ) with brown carbon, as shown in Fig. S9. 


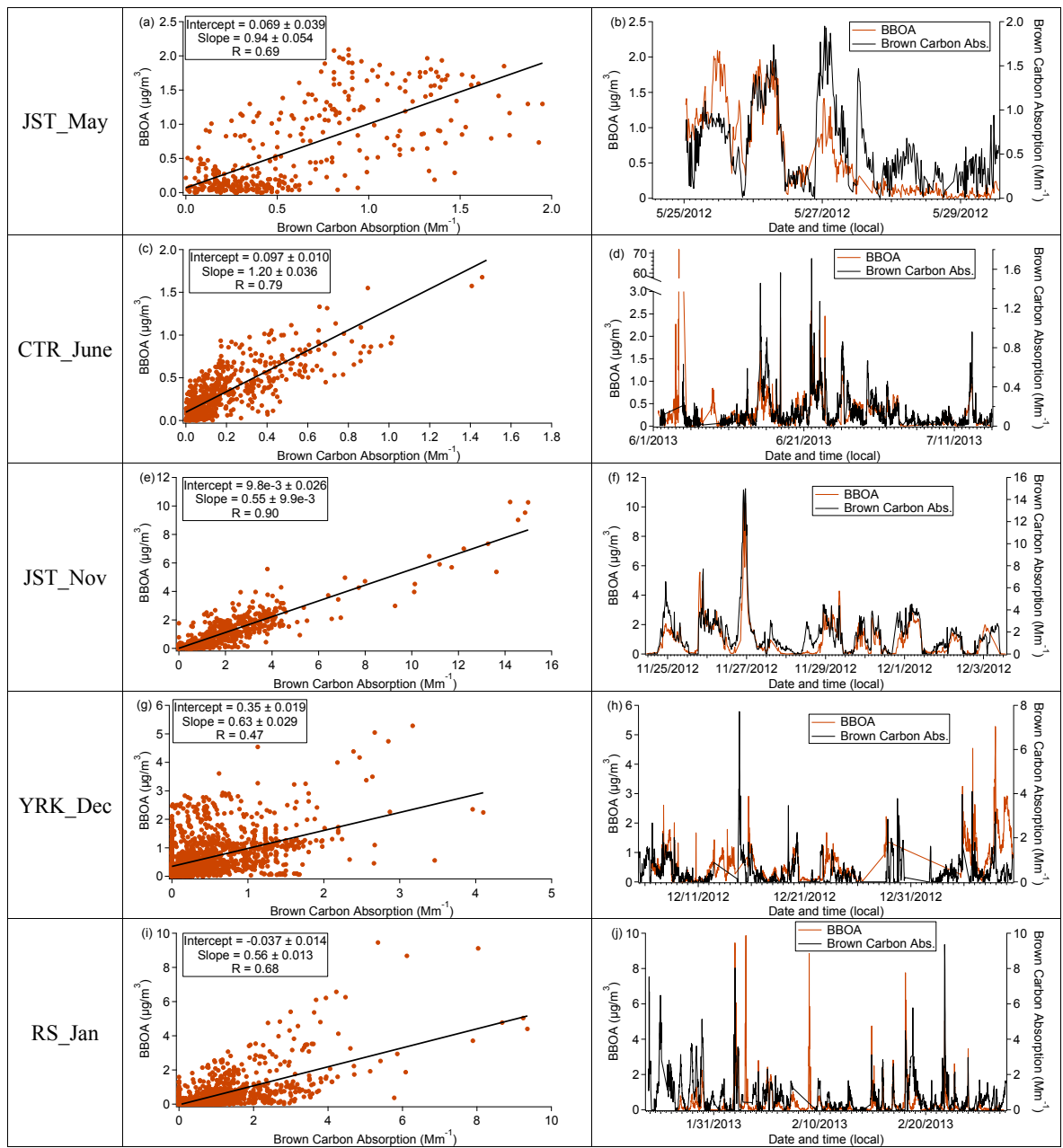

Figure 7. Scatter plot (left panel) and the time series (right panel) of BBOA and brown carbon light absorption for the data sets where a BBOA factor was resolved.

As suggested by Washenfelder et al. (2015), the difference between ambient observation and laboratory studies is possibly caused by the fact that the IEPOX-derived absorbing chromophores do not dominate the isoprene-OA mass. However, further studies are warranted to resolve this difference.

\subsubsection{MO-OOA}

Two oxygenated OA factors (MO-OOA and LO-OOA) with high but differing $\mathrm{O}: \mathrm{C}$ ratios were identified in both rural and urban sites throughout the year. MO-OOA contributes 24-49\% of total OA mass (Fig. 6). This factor has the highest $\mathrm{O}: \mathrm{C}$ ratio, indicating that it is highly oxidized. It has been shown that as OA ages in the atmosphere, the mass spectra of OA from different sources become increasingly similar to each other and resemble that of MO-OOA (Jimenez et al., 2009; Ng et al., 2010). Thus, MO-OOA likely represents a highly aged organic aerosol from multiple sources, which causes the identification of specific sources of MO-OOA to be challenging. In addition to a high degree of oxidation, other notable features of MO-OOA are its diurnal profile and ubiquitous presence. As shown in Fig. 5, in most data sets except RS_Jan the diurnal profile of MO-OOA reaches a daily maximum in the afternoon. The daytime increase in MOOOA would become more prominent after considering the dilution caused by boundary layer height expansion during the day. The similar diurnal profile has also been observed in a number of studies (Aiken et al., 2009; DeWitt et al., 2015; Hildebrandt et al., 2010; Huang et al., 2010; Setyan et al., 2012). Moreover, not only in this study has MO-OOA been identified in different sites and seasons, MO-OOA (or the OOA factor in general) was also identified in data sets obtained at multiple sites around the world, pointing to the ubiquitous nature of this OA subtype (Jimenez et al., 2009; $\mathrm{Ng}$ et al., 2010).

Possible sources of this factor have been proposed in the literature. Firstly, a number of studies proposed that the source for MO-OOA is long-range transport ( $\mathrm{Li}$ et al., 2015; Hayes et al., 2013; Robinson et al., 2011b; Raatikainen et 


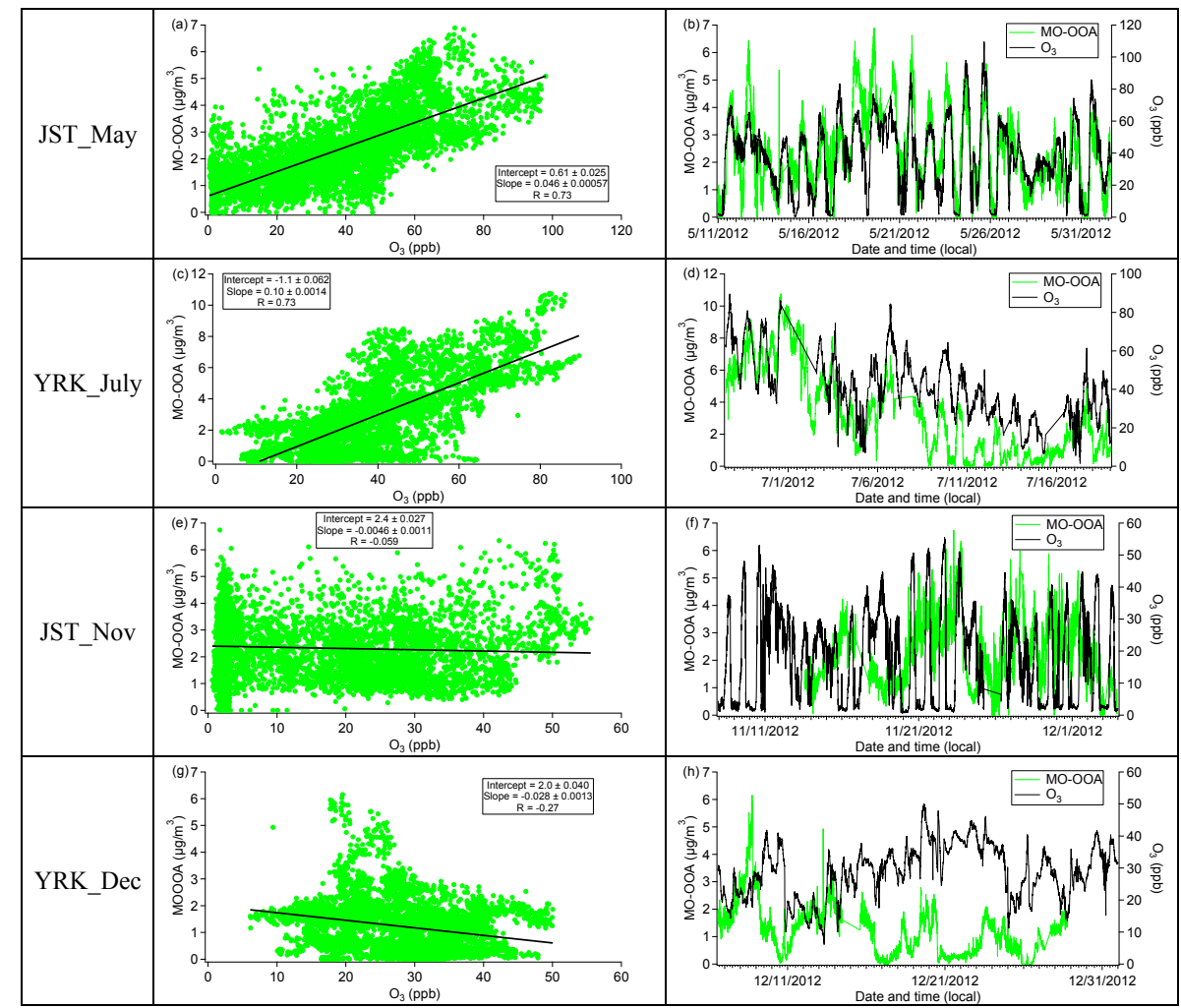

Figure 8. Scatter plot (left panel) and the time series (right panel) of MO-OOA and ozone.

al., 2010). This proposed mechanism could explain the high degree of oxidation of MO-OOA because the aerosol gets progressively more oxidized during advection, but it is unlikely to explain the well-defined diurnal profile of MOOOA (peaks in the afternoon). Secondly, humic-like substances (HULIS) are proposed to be synonymous with MOOOA because the mass spectrum and the degree of oxidation of HULIS resembles those of MO-OOA (Ng et al., 2010; El Haddad et al., 2013). A recent study by Paglione et al. (2014) performed factor analysis on nuclear magnetic resonance (NMR) measurements of water-soluble organic carbon extracted from filters collected in the Netherlands and resolved a factor with mass spectral features that are similar to HULIS. Furthermore, the authors showed that this HULIS factor correlates with the most-oxidized OOA factor $(\mathrm{O}: \mathrm{C}=0.98)$ resolved from PMF analysis of their HR-ToFAMS measurements, providing a linkage between HULIS and MO-OOA. Thirdly, the oxidation of vehicle emission or fuel combustion in general might also contribute to MOOOA mass, but such a contribution is uncertain. On the one hand, multiple studies have shown that the photooxidation of gas-phase species from direct vehicle emissions or POA evaporation could rapidly produce secondary $\mathrm{OA}$, which resembles the mass spectrum of oxygenated OA factors and could be $1-2$ orders of magnitude higher than the primary OA emissions (Nordin et al., 2013; Presto et al., 2014; Jathar et al., 2014; Platt et al., 2013). In addition, a previous study by Liu et al. (2011) showed that the carboxylic acids measured by Fourier transform infrared spectroscopy are exclusively associated with fossil fuel combustion and correlate with the PMF resolved OOA factor from HR-ToF-AMS measurements in coastal California. On the other hand, Zotter et al. (2014) showed that $>69 \%$ of MO-OOA originated from non-fossil sources in the LA basin based on a combination of radiocarbon analysis and AMS PMF analysis. By using the same method, DeWitt et al. (2015) showed that the majority of carbon in OOA is non-fossil even in an environment heavily influenced by traffic emissions, suggesting the source of MO-OOA is not vehicle emissions. Lastly, aged biomass burning is also a possible source for MO-OOA as discussed above in Sect. 4.1.4.

One interesting observation in this study is that MOOOA is well-correlated with ozone in summer $(R=0.73$ for JST_May and YRK_July) but not in winter $(R=-0.059$ and -0.27 for JST_Nov and YRK_Dec, respectively) (Fig. 8), implying that the sources of MO-OOA may vary with seasons. Considering the large biogenic VOC emissions in summer, the summer MO-OOA may be related to the oxidation of biogenic VOCs. Recently, Ehn et al. (2014) for the first time observed that monoterpene oxidation could produce large quantities of compounds with extremely low vapor pressure. As these compounds have very high $\mathrm{O}: \mathrm{C}(\sim 0.7)$, it 


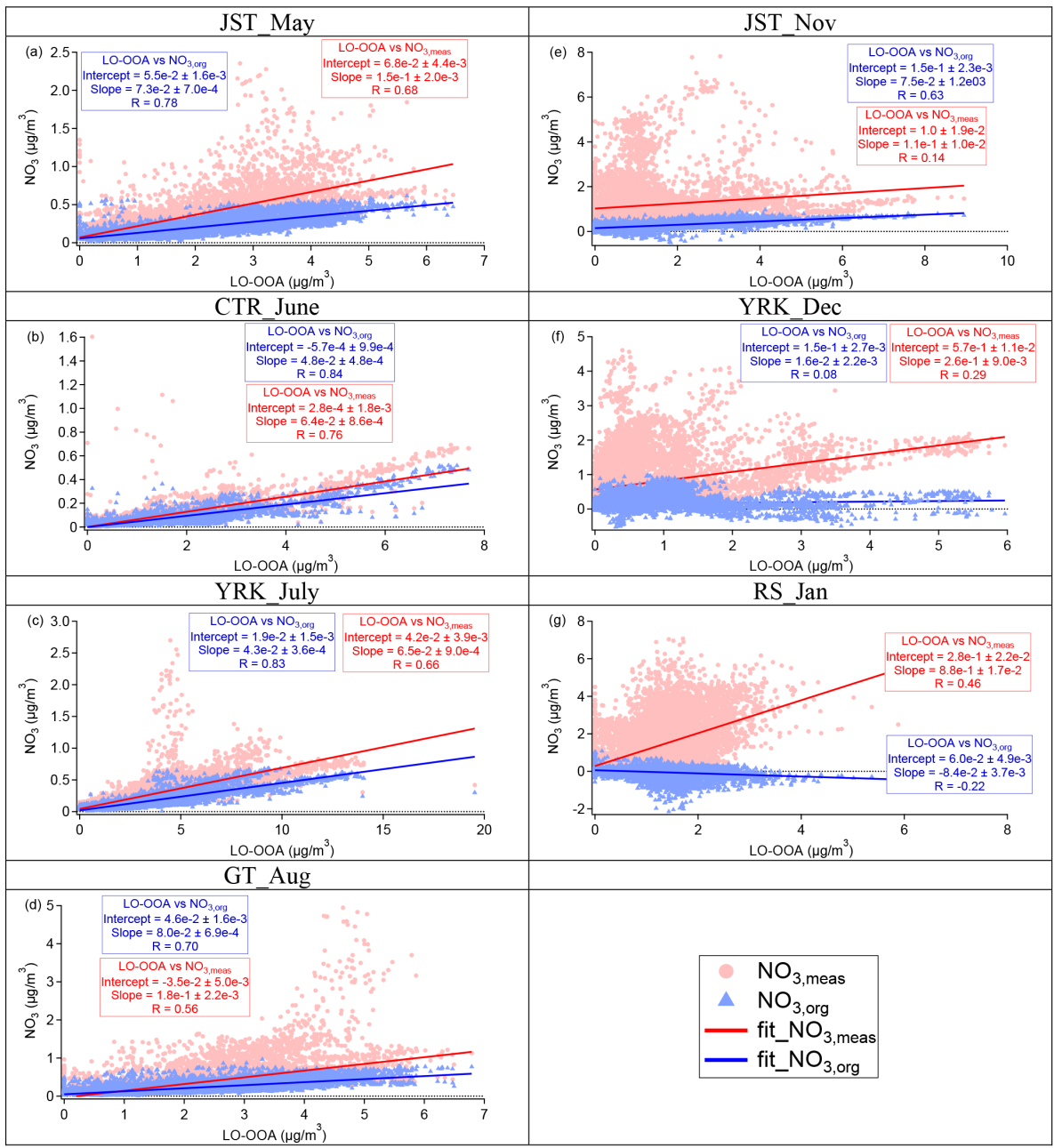

Figure 9. Scatter plot of LO-OOA vs. the total measured nitrates (i.e., $\mathrm{NO}_{3 \text {,meas }}$ ) and LO-OOA vs. estimated concentration of "nitrate functionality from organic nitrates" (i.e., $\mathrm{NO}_{3, \text { org }}$ ) by using $R_{\mathrm{ON}}=10$ in the $\mathrm{NO}_{x}^{+}$ratio method.

is possible that they serve as an important source for MOOOA. The identification of the sources of winter MO-OOA could be aided by the radiocarbon analysis. For example, if the majority of MO-OOA in winter has non-fossil sources, it could suggest that aged OA from biomass burning is an important source for MO-OOA, because biomass burning is enhanced and the emissions of biogenic VOCs are low in winter.

\subsubsection{LO-OOA}

Similar to MO-OOA, less-oxidized oxygenated organic aerosol (LO-OOA) is also observed in both rural and urban sites throughout the year. LO-OOA comprises $19-34 \%$ of total OA (Fig. 6). A key feature of LO-OOA is that it consistently exhibits a daily maximum at early morning and at night, in all data sets (Fig. 5). The similar diurnal variation of LO-OOA has also been observed in previous field measurements and thought to be primarily driven by the semi- volatile nature of LO-OOA. The LO-OOA factor identified in multiple prior field measurements has been observed to correlate with ammonium nitrate, a semi-volatile species which mainly partitions into the particle phase at night when the temperature is relatively low (Jimenez et al., 2009; Sun et al., 2012a; Zhang et al., 2011; Ulbrich et al., 2009). However, in this study, LO-OOA only shows moderate correlation with total $\mathrm{NO}_{3}$ (i.e., $\mathrm{NO}_{3 \text {, meas }}$ ) measured by the HR-ToF-AMS in summer data sets ( $R$ ranges between 0.56 and 0.76$)$ and is not correlated in winter data sets $(R$ ranges between 0.14 and 0.46) (Fig. 9 and Table 2).

While LO-OOA is only moderately, or sometimes poorly, correlated with $\mathrm{NO}_{3 \text {, meas }}$ in this study, we find improved correlation between LO-OOA and "nitrate functionality from organic nitrates" (i.e., $\mathrm{NO}_{3 \text {,org }}$ ) (Fig. 9 and Table 2). $\mathrm{NO}_{3 \text {,org }}$ is estimated by using the $\mathrm{NO}_{x}^{+}$ratio method as described in Sect. 2.5. An $R_{\mathrm{ON}}$ value of 10 is applied in this case since different $R_{\mathrm{ON}}$ values would only affect the estimated 

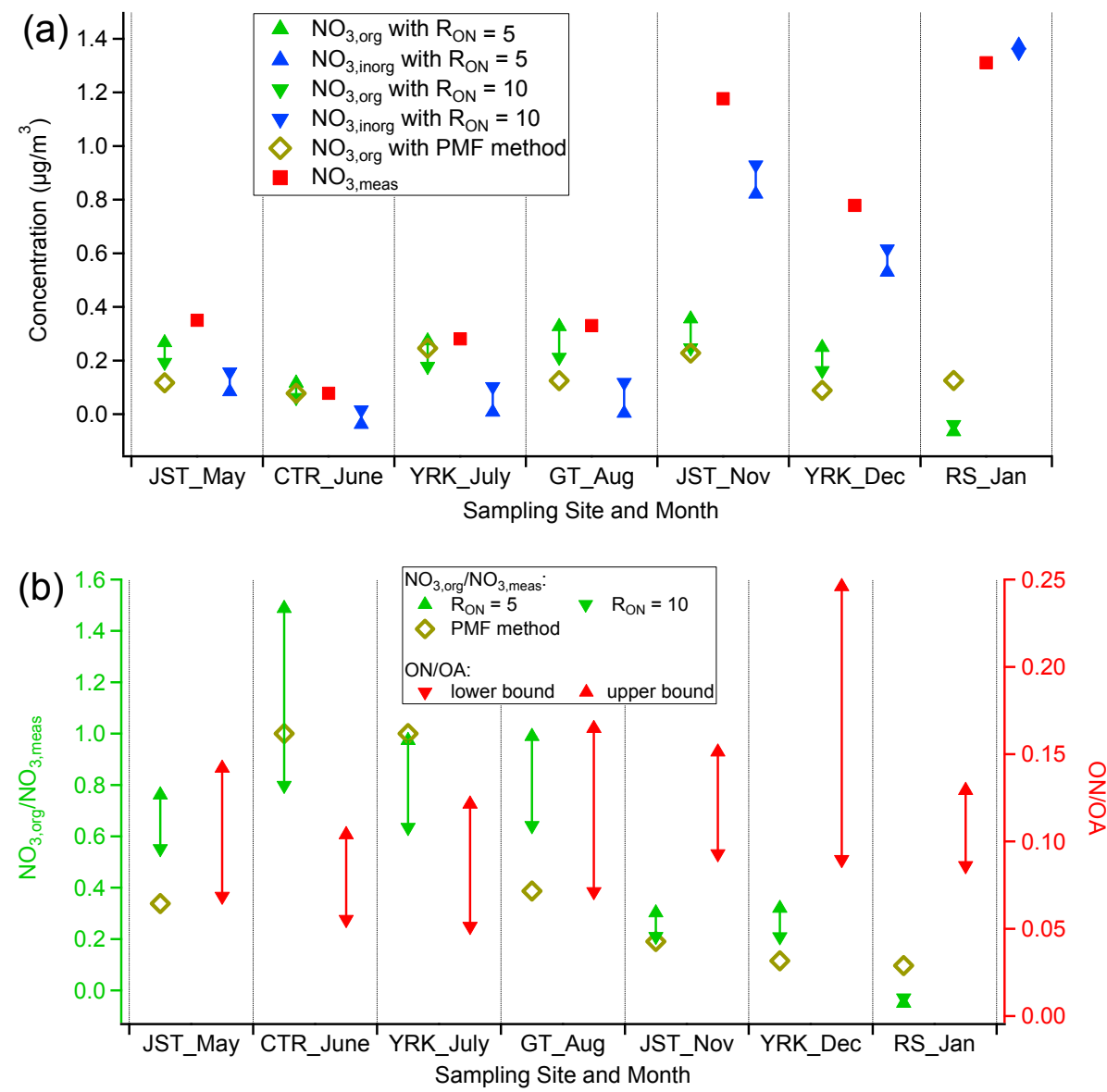

Figure 10. (a) Concentrations of total measured $\mathrm{NO}_{3}$ (i.e., $\mathrm{NO}_{3 \text {, meas }}$ ), estimated "nitrate functionality from organic nitrates" (i.e., $\mathrm{NO}_{3}$, org) by the $\mathrm{NO}_{x}^{+}$ratio method and the PMF method. (b) The contribution of $\mathrm{NO}_{3}$,org to $\mathrm{NO}_{3 \text {, meas }}$ (i.e., $\mathrm{NO}_{3 \text {, org }} / \mathrm{NO}_{3 \text {, meas }}$ ) from the $\mathrm{NO}_{x}^{+}$ratio method and the PMF method. Also shown are the estimated contribution of organic nitrates to total OA from the "best estimate" range of $\mathrm{NO}_{3 \text {, org }}$ and by assuming a molecular weight of 200 and $300 \mathrm{~g} \mathrm{~mol}^{-1}$ for organic nitrates.

concentration of $\mathrm{NO}_{3}$, org but not the correlation between $\mathrm{LO}$ OOA and $\mathrm{NO}_{3, \text { org }}$. For most data sets, LO-OOA correlates better with $\mathrm{NO}_{3}$, org than total nitrates. The biggest improvement is seen in JST_Nov, where the correlation coefficient increases from 0.14 to 0.63 . However, we also note that the correlation becomes worse for YRK_Dec and RS_Jan, which is likely caused by the small contribution of organic nitrates to total nitrates, resulting in a larger uncertainty in the $\mathrm{NO}_{x}^{+}$ ratio method (Bruns et al., 2010). In addition, the correlations

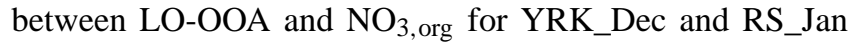
are weakened by the negative $\mathrm{NO}_{3}$, org concentration estimated from the $\mathrm{NO}_{x}^{+}$ratio method (Fig. 9). The negative values are a result of smaller $R_{\text {meas }}$ than $R_{\mathrm{AN}}$ at times (see Eq. 1), which is likely caused by variations in instrument performance (Farmer et al., 2010; Rollins et al., 2010).

\subsection{Nitrates source apportionment}

\subsubsection{Estimation of organic nitrates}

The $\mathrm{NO}_{x}^{+}$ratio method and the PMF method are applied to estimate the concentration of "nitrate functionality from organic nitrates" (i.e., $\mathrm{NO}_{3, \mathrm{org}}$ ) at different sites. The concentration of $\mathrm{NO}_{3}$,org and the mass fraction of $\mathrm{NO}_{3}$,org in total measured $\mathrm{NO}_{3}$ (i.e., $\mathrm{NO}_{3}$, meas) estimated from both methods are shown in Fig. 10. Both the $\mathrm{NO}_{x}^{+}$ratio method and the PMF method show a similar seasonality in the contribution of $\mathrm{NO}_{3 \text {, org to }} \mathrm{NO}_{3}$, meas (denoted as $\mathrm{NO}_{3}$,org $/ \mathrm{NO}_{3}$, meas), which is higher in summer than winter. However, we observe noticeable differences between the two methods. In the following, we first discuss the uncertainties associated with $\mathrm{NO}_{x}^{+}$ ratio method and PMF method. Then, we discuss how the uncertainties affect the comparison between the two methods and provide a "best estimate" range of $\mathrm{NO}_{3}$, org based on the two methods. Lastly, we use the "best estimate" range 


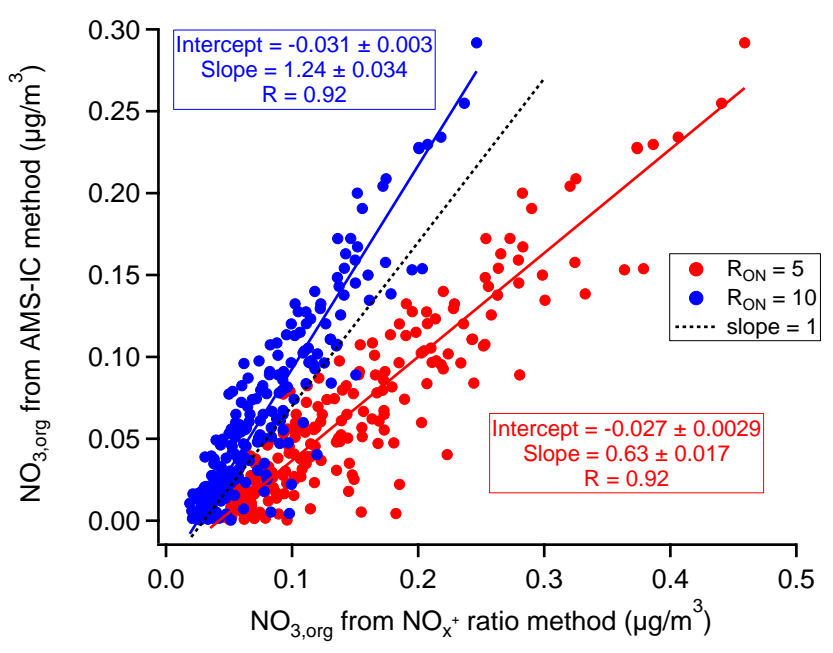

Figure 11. Comparison of estimated concentration of "nitrate functionality from organic nitrates" (i.e., $\mathrm{NO}_{3}$,org) at the Centreville (CTR) site between the AMS-IC method and $\mathrm{NO}_{x}^{+}$ratio method with $R_{\mathrm{ON}}$ values of 5 and 10 . The intercept and slope are obtained by orthogonal fit, which considers measurement errors in both dependent and independent variables. The correlation coefficient $\mathrm{R}$ is obtained by linear least-squares fit. Intercepts are within the detection limit of PILS-IC nitrate (i.e., $0.03 \mu \mathrm{g} \mathrm{m}^{-3}$ ). The $1: 1$ line is offset by the detection limit of PILS-IC nitrate (i.e., $-0.03 \mu \mathrm{g} \mathrm{m}^{-3}$ ) for visual clarity. The uncertainty of PILS-IC measurements is about $10 \%$ according to Weber et al. (2001).

of $\mathrm{NO}_{3 \text {,org }}$ to calculate the contribution of organic nitrates to OA by assuming the molecular weight of organic nitrates.

For the PMF method, the uncertainty is mainly associated with the identification of a nitrate inorganic aerosol (NIA) factor. The NIA factor is resolved in most data sets except CTR_June and YRK_July. The mass spectrum of the NIA factor is similar to the corresponding factor in Sun et al. (2012b) (Fig. S4). Specifically, it is dominated by $\mathrm{NO}^{+}$and contains some organic signals such as $\mathrm{CO}_{2}^{+}$and $\mathrm{C}_{2} \mathrm{H}_{3} \mathrm{O}^{+}$, indicating the NIA factor has a potential interference from organics. The mass fraction of organic signals in the NIA factor varies across sites, with a higher value in warmer months $(\sim 70 \%$ in JST_May and GT_Aug $)$ than colder months (16-38\% in JST_Nov, YRK_Dec, and RS_Jan) (Fig. S11). The fact that the $\mathrm{NO}^{+} / \mathrm{NO}_{2}^{+}$ratio of the NIA factor resolved from warmer months is higher than that of pure ammonium nitrate (Fig. S12) is also indicative of organic nitrate interference in the NIA factor. Conversely, the $\mathrm{NO}^{+} / \mathrm{NO}_{2}^{+}$ratio of the NIA factor resolved from colder months is closer to that of pure ammonium nitrate, suggesting less interference from organics. Thus, for the sites where a NIA factor is identified, the presence of organic nitrates in the NIA factor would result in an underestimation of $\mathrm{NO}_{3, \text { org }}$, and the underestimation is larger for warmer months (i.e., JST_May and GT_Aug). For CTR_June and YRK_July, the NIA factor is not resolved from $\mathrm{PMF}_{\text {org }+\mathrm{NO} 3}$
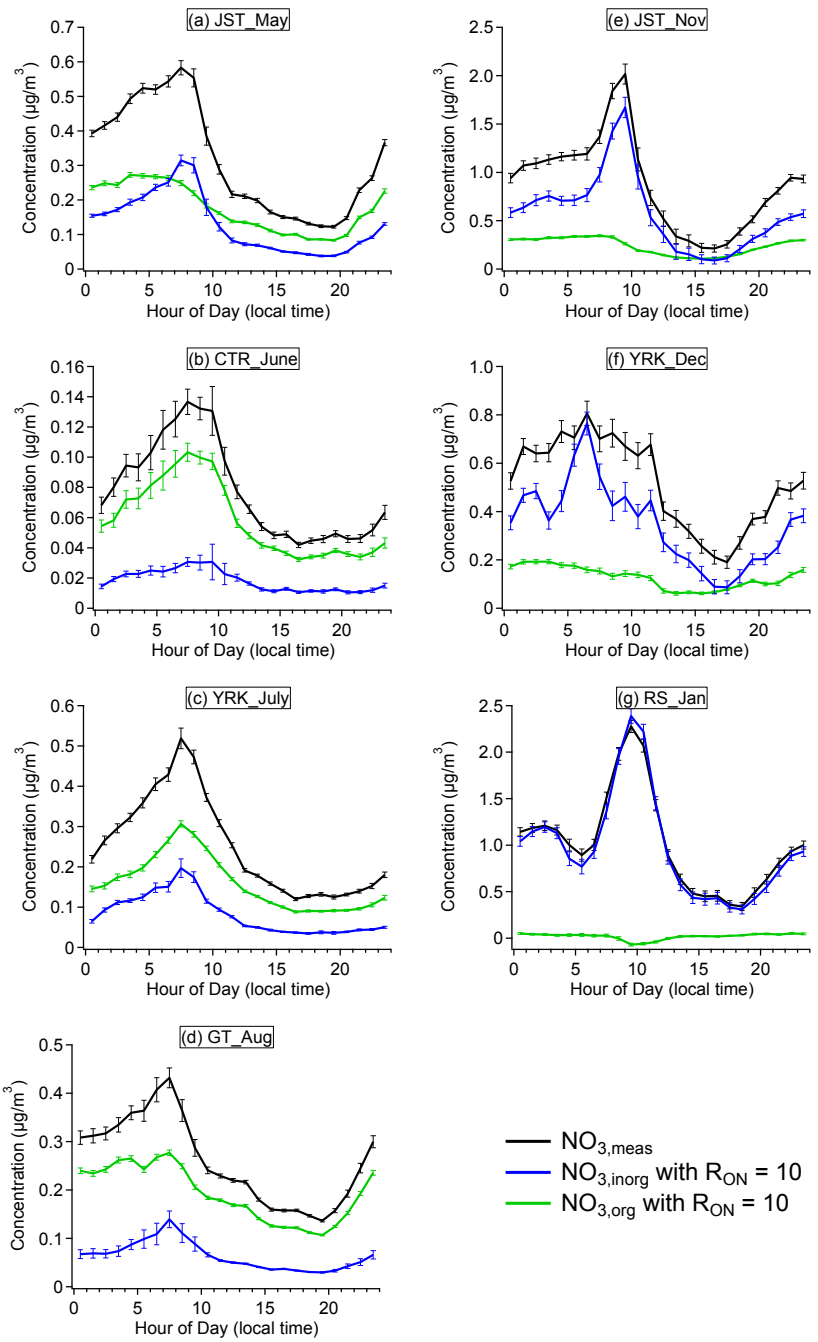

Figure 12. Diurnal variation of $\mathrm{NO}_{3}$, meas, $\mathrm{NO}_{3}$, org, and $\mathrm{NO}_{3}$, inorg for all data sets. $\mathrm{NO}_{3}$, org and $\mathrm{NO}_{3}$,inorg are estimated by the $\mathrm{NO}_{x}^{+}$ ratio method with an $R_{\mathrm{ON}}$ value of 10 . The solid lines indicate the median concentration and the error bars indicate the standard error.

analysis due likely to a small concentration of inorganic nitrates. For example, the concentrations of organics and total nitrates (i.e., $\mathrm{NO}_{3 \text {, meas }}$ ) are 5.0 and $0.1 \mu \mathrm{g} \mathrm{m}^{-3}$, respectively, for CTR_June. Even when one assumes that all the measured nitrates arise from inorganic nitrates, the nitrates/organics ratios is only $2 \%$, making it difficult for PMF to retrieve the NIA factor accurately (Ulbrich et al., 2009). Thus, for CTR_June and YRK_July, the small amount of $\mathrm{NO}_{3 \text {,inorg, }}$ which is not retrievable by PMF, was attributed to OA factors so that the PMF method would slightly overestimate $\mathrm{NO}_{3 \text {,org. }}$.

For the $\mathrm{NO}_{x}^{+}$ratio method, considering the large variation in $\mathrm{NO}_{x}^{+}$ratio for different organic nitrates, the largest uncertainty is associated with the value of $R_{\mathrm{ON}}$. Ideally, the time-dependent $R_{\mathrm{ON}}$ values should be applied. However, this is challenging because the determination of time-dependent $R_{\mathrm{ON}}$ requires measurements of every ambient organic nitrate 
species, which are not available. Knowing this, we apply $R_{\mathrm{ON}}$ values of 5 and 10 in our analysis to provide the upper and lower bounds of the estimated $\mathrm{NO}_{3, \text { org }}$ concentration for the $\mathrm{NO}_{x}^{+}$ratio method as discussed in Sect. 2.5. It is noted that for Centreville we applied a third method to calculate the concentration of $\mathrm{NO}_{3}$,org, based on the differences between HR-ToF-AMS measurements $\left(\mathrm{NO}_{3}\right.$ from both organic and inorganic species) and PILS-IC measurements ( $\mathrm{NO}_{3}$ from inorganic species only) (Xu et al., 2015; Bae et al., 2007; Orsini et al., 2003). This method, denoted as AMSIC method, is only applied for Centreville because the PILSIC was not deployed in the SCAPE study. In order to match the HR-ToF-AMS particle cut size (i.e., $\mathrm{PM}_{1}$ ), a $\mathrm{PM}_{1}$ cyclone was deployed at the inlet of PILS-IC. However, due to the transmission efficiency of $\mathrm{PM}_{1}$ cyclone, PILS-IC measurements might include contributions from particles larger than $1 \mu \mathrm{m}$ (i.e., inorganic $\mathrm{NO}_{3}$ in mineral dust). Interferences from water-soluble refractory particles (e.g., calcium or sodium nitrate) are likely small given the concentration of sodium measured by the PILS-IC with a $\mathrm{PM}_{1}$ cyclone, for example, was negligible and mostly below its detection limit $\left(0.07 \mu \mathrm{g} \mathrm{m}^{-3}\right)$ (Fig. S13). As shown in Fig. 11, The $\mathrm{NO}_{3 \text {,org }}$ estimated by the AMS-IC method falls within the range of $\mathrm{NO}_{x}^{+}$ratio method, which is defined by $R_{\mathrm{ON}}$ values of 5 and 10 , indicating the feasibility of using these two values as the upper and lower bounds to estimate $\mathrm{NO}_{3, \text { org }}$ for the $\mathrm{NO}_{x}^{+}$ratio method.

Based on the uncertainties of the PMF method and the $\mathrm{NO}_{x}^{+}$ratio method, we could explain the differences between the two methods and further combine them in order to narrow the estimation range. According to the extent of agreement between the two methods, all seven data sets are grouped into three categories: summer months (CTR_June and YRK_July), transition months (JST_May and GT_Aug), and winter months (JST_Nov, YRK_Dec, and RS_Jan).

For winter months, the PMF method shows good agreement with the $\mathrm{NO}_{x}^{+}$ratio method with a $R_{\mathrm{ON}}$ value of 10 for JST_Nov and YRK_Dec. This is consistent with the observations that the interference of organic nitrates in the NIA factor is small in winter data sets (Figs. S11 and S12) and isoprene emission is negligible in winter (Guenther et al., 2006). Thus, results from the $\mathrm{NO}_{x}^{+}$ratio method with $R_{\mathrm{ON}}=5$ (i.e., isoprene organic nitrates) are likely unrealistic. With this in mind, we combine the results from the PMF method and the $\mathrm{NO}_{x}^{+}$ratio method with $R_{\mathrm{ON}}=10$ as the "best estimate" range of organic nitrates for JST_Nov and YRK_Dec. For RS_Jan, the $\mathrm{NO}_{x}^{+}$ratio method predicts negative $\mathrm{NO}_{3 \text {, org }}$ due to $R_{\text {meas }}$ being smaller than $R_{\mathrm{AN}}$ at times (Eq. 1). In this case, the PMF method is selected as the "best estimate". Taken together, the mass fraction of organic nitrates (i.e., $\mathrm{NO}_{3 \text {,org }} / \mathrm{NO}_{3 \text {, meas }}$ ) is $0.19-0.21,0.11-0.21$, and $\sim 0.10$ for JST_Nov, YRK_Dec, and RS_Jan, respectively.

For summer months, the PMF method predicts that all the measured nitrates are from organic nitrates (i.e., $\mathrm{NO}_{3, \text { org }} / \mathrm{NO}_{3 \text {, meas }}=1$, Fig. 10), because a NIA factor is not resolved from PMF analysis and all the measured $\mathrm{NO}_{3}$ are distributed in the $\mathrm{OA}$ factors. The $\mathrm{NO}_{3}$, org estimated from the PMF method falls within the upper (i.e., $R_{\mathrm{ON}}=5$ ) and lower bound (i.e., $R_{\mathrm{ON}}=10$ ) of the $\mathrm{NO}_{x}^{+}$ratio method (Fig. 10). For CTR_June, the $\mathrm{NO}_{x}^{+}$ratio method with $R_{\mathrm{ON}}$ value of 5 predicts a $\mathrm{NO}_{3, \text { org }} / \mathrm{NO}_{3 \text {, meas }}$ ratio that is greater than 1 , which results from the assumed $R_{\mathrm{ON}}$ value (i.e., 5) being smaller than $R_{\text {meas }}$, at times (Eq. 1). Thus, the PMF method and the $\mathrm{NO}_{x}^{+}$ratio method with $R_{\mathrm{ON}}=10$ define the upper and lower bound, respectively. Accordingly, the "best estimate" range of $\mathrm{NO}_{3, \text { org }} / \mathrm{NO}_{3}$, meas is $0.80-1$ and $0.63-1$ for CTR_June and YRK_July, respectively.

For transition months (i.e., JST_May and GT_Aug), the PMF method and the $\mathrm{NO}_{x}^{+}$ratio method show large discrepancies. Compared to the PMF method, the $\mathrm{NO}_{x}^{+}$ratio method predicts 1.5-2.5 times higher $\mathrm{NO}_{3 \text {, org }}$ concentration depending on the site and $R_{\mathrm{ON}}$ value. This is likely caused by the PMF method underpredicting $\mathrm{NO}_{3 \text {, org }}$, owing to the attribution of some organic nitrates to the NIA factor. Thus, we select the $\mathrm{NO}_{x}^{+}$ratio method with $R_{\mathrm{ON}}$ values of 5 and 10 as the "best estimate" range. Accordingly, $\mathrm{NO}_{3, \text { org }} / \mathrm{NO}_{3 \text {, meas }}$ ranges $0.55-0.76$ and $0.64-0.99$ for JST_May and GT_Aug, respectively.

We also calculate the contribution of organic nitrate molecules to OA from the "best estimate" range of nitrate functionality (i.e., $\mathrm{NO}_{3}$,org). We assume that particle-phase organic nitrates have an average molecule weight of 200 and $300 \mathrm{~g} \mathrm{~mol}^{-1}$ (Rollins et al., 2012), which provides an lower and upper bound for estimating concentrations of organic nitrates. As shown in Fig. 10, organic nitrates contribute about $5-12 \%$ to total OA for summer data sets (CTR_June and YRK_July) and 9-25\% to total OA for winter data sets (JST_Nov, YRK_Dec, and RS_Jan), suggesting that organic nitrates are important components of total OA in the southeastern USA.

Figure 12 shows the diurnal variation of $\mathrm{NO}_{3, \text { org }}$ based on the $\mathrm{NO}_{x}^{+}$ratio method with an $R_{\mathrm{ON}}$ value of 10 . For most of the data sets, $\mathrm{NO}_{3 \text {,org }}$ starts increasing after sunset, which is mainly caused by the oxidation of VOCs by nitrate radi-

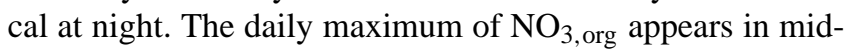
morning (i.e., $\sim 08: 00$ ), which is likely because photooxidation of VOCs in the presence of $\mathrm{NO}$ (i.e., $\mathrm{RO}_{2}+\mathrm{NO}$ pathway) also contributes to organic nitrate when the NO concentration is highest.

\subsubsection{Nitrate seasonal variation}

As shown in Table 1 and Fig. 2, the total nitrate concentration is higher in winter $\left(0.8-1.4 \mu \mathrm{g} \mathrm{m}^{-3}, 10-16 \%\right.$ of total NR-PM 1 ) than in summer $\left(0.1-0.4 \mu \mathrm{g} \mathrm{m}^{-3}, 2-3 \%\right.$ of total NR-PM 1 ). Based on the $\mathrm{NO}_{x}^{+}$ratio method, $\mathrm{NO}_{3}$,inorg is greatly enhanced in winter relative to summer. For example, the concentration of $\mathrm{NO}_{3}$, inorg increases from $0.12 \mu \mathrm{g} \mathrm{m}{ }^{-3}$ (average of upper and lower bound of the $\mathrm{NO}_{x}^{+}$ratio method) in May to $0.88 \mu \mathrm{g} \mathrm{m}^{-3}$ in November for the JST site (Fig. 10). 
Similarly, $\mathrm{NO}_{3 \text {,inorg }}$ shows a 10 -fold increase for YRK_Dec compared to YRK_July.

The seasonal variation of inorganic nitrates could possibly be caused by its semi-volatile nature and varying $\mathrm{NO}_{x}$ emissions. Based on volatility measurements by a thermal denuder, Huffman et al. (2009) showed that ammonium nitrate is very volatile and its gas/particle partitioning is largely affected by temperature. The average temperature in summer is about $15^{\circ} \mathrm{C}$ higher than that in winter (Table 1). According to laboratory measurements of ammonium nitrate volatility, a $15^{\circ} \mathrm{C}$ increase in temperature would lead to the evaporation of $60 \%$ of nitrate mass (Huffman et al., 2009). In addition to volatility, the winter enhancement of inorganic nitrates is related to higher $\mathrm{NO}_{x}$ levels, which is the major source for inorganic nitrates and largely elevated in winter in the southeastern USA (Blanchard et al., 2013). For example, as shown in Table 1, the $\mathrm{NO}_{x}$ concentration in JST_Nov $(50.5 \mathrm{ppb})$ is 3.5 times higher than that in JST_May (14.4 ppb). Thus, the lower temperature and higher $\mathrm{NO}_{x}$ levels in winter than summer likely compensate for the weaker photooxidation and result in the increase in inorganic nitrates. Interestingly, we observe a rush hour peak (around 09:00) in the diurnal trend of total nitrates at urban sites in winter (JST_Nov and RS_Jan). This rush hour peak is primarily from inorganic nitrates supported by the following evidence: (1) the $R_{\text {meas }}$ is close to $R_{\mathrm{AN}}$ during the rush hour period (Fig. S15); (2) the rush hour peak only exists in the diurnal profile of $\mathrm{NO}_{3 \text {,inorg }}$ (Fig. 12); and (3) the coincident peak in the diurnal trend of $\mathrm{NH}_{4}$ (Fig. 3). Early morning peaks in inorganic nitrates were also consistently seen by a variety of online instruments as part of the Atlanta Supersite Experiment at the JST site (Weber et al., 2003). In Mexico City, Hennigan et al. (2008) attributed the fast production of inorganic nitrates mainly to secondary formation from photooxidation of $\mathrm{NO}_{x}$ and subsequent partitioning of $\mathrm{HNO}_{3}$. The rush hour peak of inorganic nitrates disappears rapidly, which is likely caused by evaporation and dilution as the planetary boundary layer height increases (Hennigan et al., 2008).

The concentration of $\mathrm{NO}_{3}$,org is slightly higher in summer, but its seasonal variation is not as strong as $\mathrm{NO}_{3}$, inorg (Table 2 and Fig. 10). This is likely due to the compensating effects of source strength and gas/particle partitioning. The organic nitrates mainly originate from VOC oxidation by the nitrate radical and/or photooxidation in the presence of $\mathrm{NO}_{x}$. The VOC concentrations are higher in summer due to stronger biogenic emissions, which would provide sources for organic nitrates. However, the temperature is higher in summer than winter, which would hinder the partitioning of organic nitrates into the particle phase.

\subsection{Aerosol spatial variability}

The spatial variability of organics, sulfate, ammonium, and total nitrate in the greater Atlanta area is investigated by comparing ACSM measurements (stationary at the GT site)

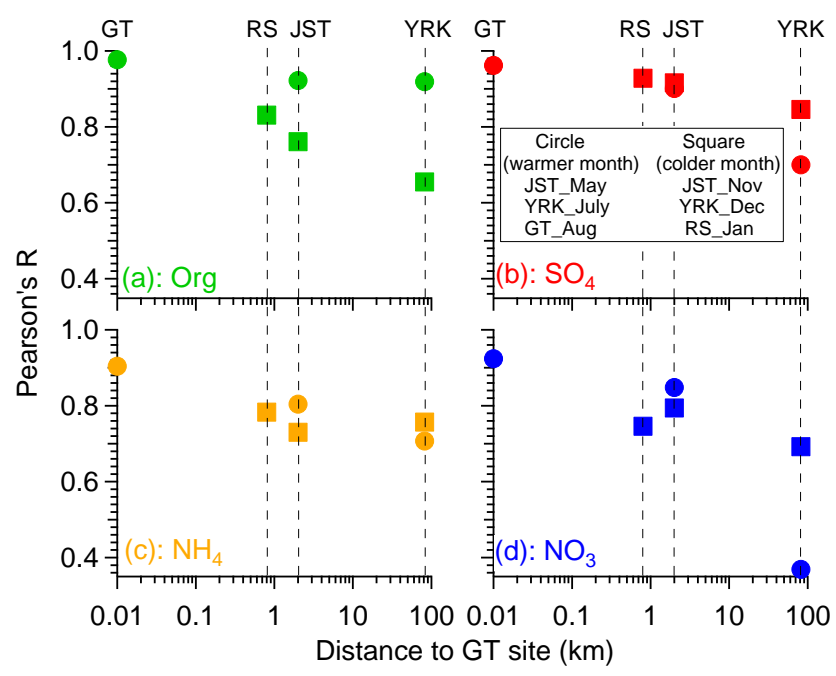

Figure 13. Correlation coefficients for NR-PM 1 species between ACSM measurements (stationary at the GT site) and HR-ToF-AMS measurements (rotating among different sites). Values are plotted vs. the relevant distance of the measurement site from the GT site. The dotted lines represent the sampling sites where the HR-ToFAMS measurements were made.

with HR-ToF-AMS measurements (rotating among different sites). Figure 13 shows the correlation coefficients for NR$\mathrm{PM}_{1}$ species between ACSM measurements (stationary at the GT site) and HR-ToF-AMS measurements (rotating among different sites). Detailed comparisons, in terms of time series and scatter plots, are shown in Fig. S14. The ACSM and HRToF-AMS were compared side-by-side at the GT site from 20 July to 04 September 2012 and the time series of the species measured by the two instruments are well correlated ( $R=0.95,0.93,0.82,0.85$ for organics, sulfate, ammonium, and total nitrate, respectively) and agree within instrument uncertainty (i.e., 20-35\%) (Bahreini et al., 2009).

As expected, the correlation gets weaker as the distance between the GT site and other sampling sites increases. Surprisingly, the organic correlation coefficient in July is 0.92 between GT and YRK sites, which have considerable spatial separation (i.e., $70 \mathrm{~km}$ ), indicating that the organics are uniformly distributed in the greater Atlanta area in summer time. In contrast, the organic correlation coefficient between GT and YRK decreases to 0.66 in winter. Unlike organics, the correlation in $\mathrm{SO}_{4}$ between GT and YRK is similarly good in both summer and winter $(R=0.7$ and 0.85 for summer and winter, respectively). Our observation is generally consistent with the previous study by Zhang et al. (2012), who showed that WSOC, and to a less extent $\mathrm{SO}_{4}$, are spatially homogeneous in the southeastern USA based on results from daily-average filter measurements (one filter in every 6 days) in 2007. The authors attributed the uniform distribution of WSOC and $\mathrm{SO}_{4}$ largely to stagnant air masses in southeastern USA during summer time and both long-lived secondary WSOC and $\mathrm{SO}_{4}$ eventually spread across the region, 
although somewhat higher WSOC spatial correlations compared to $\mathrm{SO}_{4}$ were thought to be due to widely distributed SOA precursor emissions compared to point sources for $\mathrm{SO}_{2}$. Hidy et al. (2014) also showed that secondary species, like $\mathrm{SO}_{4}$, have weaker rural and urban contrast in the southeastern USA, though only yearly average data were considered in that study.

Although meteorology plays an important role in the spatial variability of aerosol, it alone cannot explain the seasonality of the OA spatial variability. For example, meteorology should have the same effect on the regional variability of $\mathrm{SO}_{4}$ and $\mathrm{OA}$. However, while $\mathrm{SO}_{4}$ is uniformly distributed in both summer and winter, OA is more uniform in summer than winter, suggesting other factors also influence the spatial variability of OA. The seasonality of OA spatial variability (i.e., more spatially homogeneous in summer compared to winter) is probably affected by the seasonal variation of OA sources in addition to meteorology. As shown in Fig. 6, SOA is the dominant source for total OA (69-100\% of OA) in summer for both rural and urban sites. This likely arises from the fact that biogenic VOCs, which are important precursors for SOA, are abundant and widely distributed in the southeastern USA during summer time (Guenther et al., 2006). Thus, SOA is regional and the dominant component of OA, leading to the uniform distribution of OA. In contrast, POA concentration varies greatly between urban and rural sites. In winter, while the SOA still dominates total OA at rural sites, the POA is comparable with SOA at urban sites (Fig. 6). This is because the concentration of regional SOA decreases due to weaker photochemical activity and lower biogenic VOCs emissions in winter, but the concentration of $\mathrm{POA}(\mathrm{HOA}+\mathrm{BBOA}+\mathrm{COA})$ is relatively constant or even increases. This is likely due to elevated primary emissions and reduced evaporation and dispersion, which are associated with lower temperatures in winter (Fig. 6). Thus, the facts that POA is not uniformly distributed and that the concentration of POA is comparable to SOA possibly lead to the spatial non-uniformity of $\mathrm{OA}$ in winter.

\subsection{Interpretation of long-term measurements}

In this section, we compare our observations from short-term detailed aerosol chemical measurements with those from long-term and more basic measurements to test the validity of our conclusions. Further, based on our extensive measurements, we attempt to provide insights into interpreting longterm observations.

\subsubsection{OA diurnal variation}

By investigating the diurnal pattern of organic carbon (OC) from 01 June to 15 July of each year (from 2000 to 2013) in Centreville, rural Alabama, Hidy et al. (2014) observed that OC shows consistently weak diurnal variability. Similarly, Zhang et al. (2012) observed that water-soluble organic car-

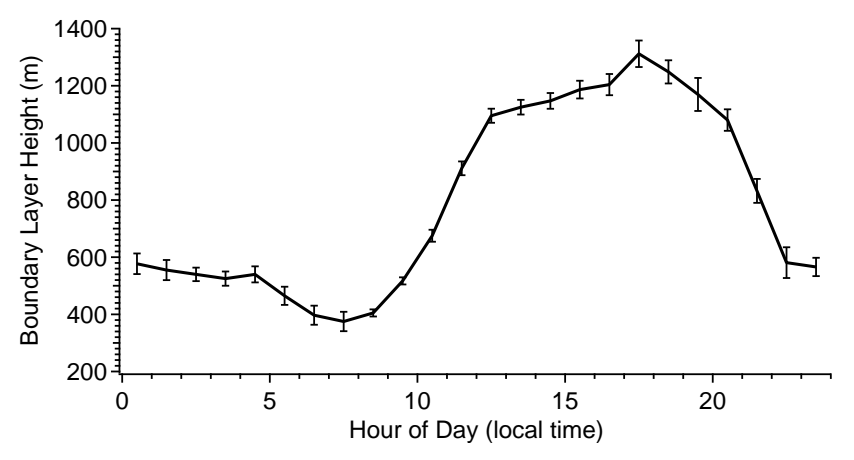

Figure 14. Diurnal variation of boundary layer height for CTR_June. The solid line indicates the median concentration and the error bars indicate the standard error.

bon, which is a surrogate for SOA (in summer), only shows a moderate increase in the daytime in Jefferson Street and Yorkville, GA, during 2008 summer. In this study, we find that OA shows little diurnal variability in summer data sets (Fig. 3), which is consistent with long-term observations and previous studies.

The lack of a prominent daytime increase in the $\mathrm{OA}$ in summer could appear to discount the role of photochemistrydriven secondary OA formation. However, a number of factors need to be considered, such as the changes in planetary boundary layer height, contribution of various sources to OA, and temperature-dependent gas/particle partitioning. Firstly, the rapid expansion of the boundary layer during the day may dilute the OA concentration. In Centreville, the boundary layer height was measured by a ceilometer. The diurnal variation of BLH is shown in Fig. 14. The BLH typically peaks (i.e., $1300 \mathrm{~m}$ ) at 17:00 and exhibits a daily minimum (i.e., $375 \mathrm{~m}$ ) at 07:00. In order to remove the effect of BLH-driven dilution on the diurnal variation of OA, we multiply the OA diurnal profile by BLH. The interpretation of the product of the concentration of OA (i.e., $\mu \mathrm{g} \mathrm{m}^{-3}$ ) times BLH (i.e., $\mathrm{m}$ ) is the integrated column concentration of OA (i.e., $\mu \mathrm{g} \mathrm{m}^{-2}$ ) from ground to the top of boundary layer over a unit surface area, assuming the OA is well-mixed in the boundary layer. The value of $\mathrm{OA} * \mathrm{BLH}$ would be conserved if there were no gain or loss of OA in the column regardless of the change of BLH. Thus, this value could indicate the net gain or loss of OA in the column without the effect of BLH-driven dilution. As shown in Fig. 3d, the OA*BLH increases rapidly starting at $\sim$ 07:00 and reaches a daily maximum at $\sim 17: 00$. The evident peak in the diurnal variation of $\mathrm{OA} * \mathrm{BLH}$ suggests a substantial OA production in the day, and that the relatively flat $\mathrm{OA}$ diurnal variation (i.e., $\mu \mathrm{g} \mathrm{m}^{-3}$ ) is largely caused by the BLH-driven dilution. For the cases where boundary layer height data are not available, normalizing $\mathrm{OA}$ by $\mathrm{CO}$ is often utilized in the literature to minimize the effect of dilution, considering $\mathrm{CO}$ as an inert species. By using this method, Blanchard et al. (2011) and Zhang et al. (2012) showed that $\mathrm{OC} / \mathrm{CO}$ and WSOC/CO exhibit 


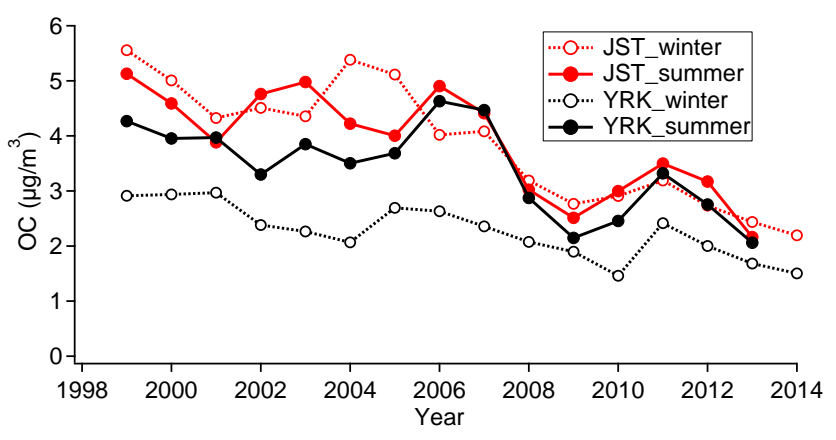

Figure 15. Mean seasonal concentrations of organic carbon at the Jefferson Street (JST) and the Yorkville (YRK) sites. Summer is June - August. Winter is December-February.

pronounced daytime increase, suggesting that the expansion of boundary layer would weaken the OA diurnal variation. The fact that both OC/CO and WSOC/CO peaks in the day implies that photochemistry-driven SOA production is an important source of OA.

Secondly, the time-dependent contributions of various sources to total OA could also affect its diurnal profile. As shown in Fig. 5, the various OA sources resolved by PMF analysis have distinctly different diurnal trends, indicating that their contributions to total OA vary throughout the day. Primary sources such as HOA and COA peak during rush hours and meal times, respectively. The contributions of isoprene-OA and MO-OOA to total OA are largest in the afternoon and decrease after sunset. In contrast, another SOA source, LO-OOA, peaks in the early morning and at night, as the formation of LO-OOA is proposed to mainly correspond to nocturnal nitrate radical oxidation of biogenic VOCs in summer (Xu et al., 2015). Therefore, different diurnal trends of various OA sources compensate each other, which possibly results in the weak diurnal variation of total OA.

Specifically, LO-OOA, which exhibits a daily maximum at night, compensates for the decrease of other OA sources after sunset and results in the relatively flat total OA diurnal profile. This has important implications in interpreting non-speciated OC measurements. For example, Hennigan et al. (2009) observed a substantial nocturnal increase of gas-phase WSOC but not an accompanied increase in particle-phase WSOC in Atlanta during summer. The authors hypothesized that the differences between gas-phase and particle-phase WSOC are caused by the oxidation of $\alpha$-pinene and isoprene by $\mathrm{NO}_{3}^{*}$ radicals producing substantial amounts of gas-phase WSOC but little particle-phase WSOC. Though it is plausible that $\alpha$-pinene $+\mathrm{NO}_{3}^{*}$ and isoprene $+\mathrm{NO}_{3}^{-}$reactions produce more volatile products than low-volatility products, our study shows that there is indeed substantial nocturnal SOA production (i.e., LO-OOA), which likely corresponds to the nocturnal increase in gas-phase WSOC in Hennigan et al. (2009) but is not clearly discernible

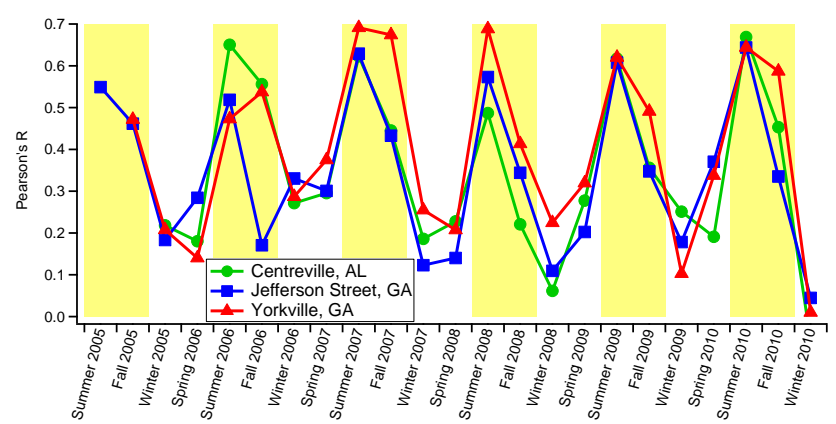

Figure 16. The seasonality of the correlation between organic carbon and sulfate at the Jefferson Street (JST), Yorkville (YRK), and Centreville (CTR) sites. Seasons are by grouped by calendar months (spring is March-May, summer is June-August, fall is SeptemberNovember, and winter is December-February).

in particle-phase WSOC due to the compensation by the decreasing concentrations of other OA sources at night.

In addition, temperature-dependent gas/particle partitioning also plays a role in OA diurnal variation. As the temperature is higher during day, the gas/particle partitioning would favor the gas-phase and hence lower the particle-phase concentration. Taken together, the weak diurnal variation of OA in summer is likely caused by changes in boundary layer height and the varying contribution of various OA sources throughout the day, which does not contradict the importance of photochemistry-driven SOA production. Especially LO-OOA, which is likely related to $\mathrm{NO}_{3}^{*}$ chemistry, peaks at night and compensates the nocturnal decrease of other SOA sources. In fact, the importance of photochemistry can be gained by comparing OA diurnal profile of summer and winter. As the photochemistry is relatively weaker in winter, daytime SOA production is suppressed, which results in OA reaching a daily minimum during daytime in winter data sets (Fig. 3).

\subsubsection{Urban and rural contrast of $\mathrm{OA}$ seasonality}

In this study, we observe that the seasonality of OA behaves differently between urban and rural sites. For example, while the OA concentration is relatively constant between summer and winter for the urban JST site $\left(9.1 \mu \mathrm{g} \mathrm{m}^{-3}\right.$ in May vs. $7.9 \mu \mathrm{g} \mathrm{m}^{-3}$ in November), the OA concentration is $\sim 4$ times higher in summer than winter for the rural YRK site (11.2 $\mu \mathrm{g} \mathrm{m}^{-3}$ in July vs. $3.2 \mu \mathrm{g} \mathrm{m}^{-3}$ in December). Our observations are consistent with the long-term measurements from the SEARCH network. Figure 15 shows the seasonal average OC concentration measured in JST and YRK from 1999 to 2013. Despite the decreasing trend of OC in the past 14 years, which has been noted and discussed extensively in Hidy et al. (2014), we note that the OC concentration is similar between summer and winter at the JST site, but OC is elevated in summer compared to winter for the YRK site. The urban and rural contrast of OA seasonality is likely caused by 
the fact that OA sources are different at urban and rural sites. As shown by PMF analysis on our short-term measurements, the total OA at the rural YRK site is dominant by SOA in both summer and winter (SOA/OA $=100$ and $78 \%$ for summer and winter, respectively, Fig. 6), but the concentration of SOA is lower in winter when the SOA formation is depressed due to low biogenic VOCs emissions and weak photochemical activity. For the urban JST site, in contrast, POA accounts for a large fraction of total OA (30-48\%, depending on the month). Though the SOA formation is also depressed in winter at urban sites, the decrease in SOA concentration is compensated by the increase in POA concentration from vehicles and cooking (Fig. 6). Thus, the OA at JST is relatively constant between summer and winter. The changing composition of the OA also implies differing aerosol toxicity and health impacts not discernible from measurements of total OA (or OC) (Verma et al., 2015). The fairly flat seasonal trend in OA or OC at urban sites has not been captured by current models. All 31 models reviewed in a recent study by Tsigaridis et al. (2014) predicted higher OC concentration in summer than winter for urban monitoring sites in Georgia.

\subsubsection{Correlation between $\mathrm{OC}$ and sulfate}

Based on the OC and sulfate measurements (2005-2010) from three SEARCH network sites (Centreville, Jefferson Street, and Yorkville), we find that regardless of the sampling sites, the correlation between OC and sulfate has a distinct seasonal variation, with the best correlation in summer ( $R$ ranging 0.47-0.69) and worst in winter ( $R$ ranging $0.01-0.33$ ) (Fig. 16). Since sulfate is mostly secondary in the southeastern USA, one possible explanation for the seasonality of the correlation between OC and sulfate is that the majority of OC is secondary in summer but not in winter, which is supported by the OA source apportionment in this study. It is also likely that sulfate is directly involved in the OA production in summer. Specifically, Xu et al. (2015) found that sulfate directly and largely mediates the formation of isoprene-OA (18-36\% of total OA in summer) in the southeastern USA, instead of particle water content and/or particle acidity, as previous studies have suggested.

\section{Conclusion}

Nearly 1 year of measurements were performed across multiple sites in the southeastern USA with a variety of online instruments, with the focus on HR-ToF-AMS data in this study. We find that organics are the dominant components of the NR-PM 1 at both rural and urban sites throughout the year. The OA diurnal profile shows little variation in summer data sets and peaks at night in winter data sets. The lack of midday enhancement in OA diurnal profile is likely caused by the expansion of boundary layer in the day and compensating effects of various OA factors. The OA measured at different sampling sites and seasons has a similar degree of oxidation. Sulfate contributes the second highest to NR-PM mass concentration. Sulfate concentration is higher in summer ( 3.0 to $4.0 \mu \mathrm{g} \mathrm{m}^{-3}$ ) than winter $\left(1.4\right.$ to $\left.1.7 \mu \mathrm{g} \mathrm{m}^{-3}\right)$ due probably to stronger photochemistry in summer. In contrast to sulfate, the inorganic nitrate concentration is estimated to be 3 times higher in winter than summer. This is likely caused by higher $\mathrm{NO}_{x}$ levels in winter, which serve as the source for inorganic nitrates and the semi-volatile nature of inorganic nitrates which tend to partitions into the particle phase when the temperature is low.

PMF analysis reveals that the OA has various sources in the southeastern USA, which changes between seasons and sampling sites (rural vs. urban). HOA and COA, which arise from primary vehicle emissions and cooking, respectively, are important but not dominant OA sources for urban sites. BBOA concentrations show clear enhancements in winter compared to summer. In addition, biomass burning is found to be an important, but not exclusive, source for brown carbon in the southeastern USA. Isoprene-derived OA, which is from the reactive uptake of isoprene epoxides in the presence of hydrated sulfate, only exists in warmer months (MayAugust) when isoprene emissions are substantial. In addition to rural sites, isoprene-OA is resolved from urban sites where the majority of peroxy radicals are believed to react with $\mathrm{NO}_{x}$. We note that $f_{\mathrm{C} 5 \mathrm{H} 6 \mathrm{O}+}$, which has been used as a marker for isoprene-OA, ranges from 0.9 to $2.3 \%$ and is higher in the isoprene-OA factor from rural sites than urban sites. One possible source of isoprene-OA in urban sites is transport. However, transport would not likely result in the reproducible diurnal profile of isoprene-OA, which peak in early afternoon. Instead, isoprene-OA in urban sites more likely comes from local production, as a recent study showed that IEPOX could be produced in the presence of $\mathrm{NO}_{x}(\mathrm{Ja}-$ cobs et al., 2014). LO-OOA and MO-OOA are resolved from both rural and urban sites throughout the year. LO-OOA shows improved correlation with estimated "nitrate functionality from organic nitrates" (i.e., $\mathrm{NO}_{3, \text { org }}$ ) than total nitrates (i.e., $\mathrm{NO}_{3}$,meas). In addition, both LO-OOA and estimated

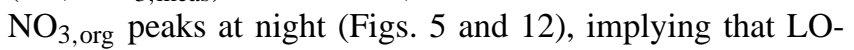
OOA could arise from nighttime oxidation of biogenic VOCs by nitrate radicals. Unlike isoprene, monoterpene emissions occur year-round and continue into the night. The prevalence of the LO-OOA factor at all sites year-round points to the important contribution of monoterpene SOA to the total OA budget in the southeastern USA. As the most oxidized OA factor, MO-OOA reaches a daily maximum in the afternoon and likely contains aged OA from various sources, such as vehicle emission, biomass burning, and biogenic VOCs. We find that the correlation between MO-OOA and ozone is substantially better in summer than winter, suggesting that the sources of MO-OOA might vary with season.

In order to estimate the organic nitrate contribution to OA, we apply and evaluate three methods, i.e, $\mathrm{NO}_{x}^{+}$ratio method, PMF method, and AMS-IC method. Despite the uncertainty 
of the $\mathrm{NO}_{x}^{+}$ratio method (i.e., the values of $R_{\mathrm{ON}}$ and $R_{\mathrm{AN}}$ ) and the PMF method (i.e., the separation of pure NIA factor), both methods provide reasonable results in separating the measured total nitrates into nitrate functionality from inorganic and organic nitrates. The "nitrate functionality from organic nitrates" (i.e., $\mathrm{NO}_{3, \text { org }}$ ) accounts for about 63-100 and $10-20 \%$ of total measured nitrate (i.e., $\mathrm{NO}_{3 \text {, meas }}$ ) in summer and winter, respectively. Furthermore, we estimate the contribution of organic nitrates to total OA based on estimated $\mathrm{NO}_{3 \text {,org }}$ and assumed molecular weight of bulk organic nitrates. Depending on location, season and estimation method, organic nitrates account for about 5-25\% of total OA, which indicates that organic nitrates are important components in the ambient aerosol.

The spatial distribution of OA is investigated by comparing ACSM measurements (stationary at the GT site) and HRToF-AMS measurements (rotating among different sites). In summer, OA is spatially homogeneous as suggested by the good correlation $(R=0.92)$ in July between the GT and YRK sites, which are $70 \mathrm{~km}$ apart. The spatial homogeneity of OA in summer is likely caused by SOA being the dominant source of OA for both urban and rural sites. The parameters such as temperature, solar radiation, and precursor VOCs, which have great influences on SOA formation, are similar between urban and rural sites. Compared to summer, the OA is less spatially homogenous in winter. The correlation coefficient of OA between GT and YRK decreases to 0.66 in winter. This is likely due to the elevated contribution from POA to total OA in winter and the spatially inhomogeneous distribution of POA. Meteorology also plays a role in the OA spatial distribution, but it alone is unlikely to explain the observation.

We show that short-term and extensive measurements can help interpret long-term basic measurements. For example, consistent with long-term (1999-2013) OC measurements from the SEARCH network, we also observe that the seasonal variation of OA has some urban and rural contrasts. While the OA concentration is similar between summer and winter for the urban JST site, it increases by a factor of 4 from winter to summer for the rural YRK site according to our year-long observations. PMF analysis suggests that the different OA seasonality between urban and rural sites is likely due to the varying strength of OA sources. For rural sites, SOA represents the dominant fraction of OA in both summer and winter, but SOA concentration is much lower in winter. For urban sites, in contrast, the decrease in SOA concentration in winter is compensated by the increase in POA concentration due to less dispersion from lower boundary layer heights, leading to a relatively constant total OA concentration compared to summer. In addition, analysis of long-term $\mathrm{OC}$ and sulfate measurements from the SEARCH network shows that the correlation between OC and sulfate is substantially better in summer than winter, consistent with our source apportionment results that the majority of OA is secondary in summer. The better correlation of $\mathrm{OC}$ and sulfate in summer also supports that sulfate directly mediates the formation of isoprene SOA (Xu et al., 2015), which is only present in warmer months.

\section{The Supplement related to this article is available online at doi:10.5194/acp-15-7307-2015-supplement.}

Acknowledgements. This publication was made possible by US EPA grant R834799. This publication's contents are solely the responsibility of the grantee and do not necessarily represent the official views of the US EPA. Further, US EPA does not endorse the purchase of any commercial products or services mentioned in the publication. Measurements in SOAS are supported by the NSF under grant number 1242258. S. Suresh acknowledges support from the Air Products Undergraduate Research Program and the President's Undergraduate Research Award (PURA) at Georgia Tech. The authors thank the SEARCH personnel for their many contributions. Without their support this work would not have been possible.

Edited by: S. Gilardoni

\section{References}

Aiken, A. C., Decarlo, P. F., Kroll, J. H., Worsnop, D. R., Huffman, J. A., Docherty, K. S., Ulbrich, I. M., Mohr, C., Kimmel, J. R., Sueper, D., Sun, Y., Zhang, Q., Trimborn, A., Northway, M., Ziemann, P. J., Canagaratna, M. R., Onasch, T. B., Alfarra, M. R., Prevot, A. S. H., Dommen, J., Duplissy, J., Metzger, A., Baltensperger, U., and Jimenez, J. L.: O/C and OM/OC ratios of primary, secondary, and ambient organic aerosols with highresolution time-of-flight aerosol mass spectrometry, Environ Sci Technol, 42, 4478-4485, doi:10.1021/Es703009q, 2008.

Aiken, A. C., Salcedo, D., Cubison, M. J., Huffman, J. A., DeCarlo, P. F., Ulbrich, I. M., Docherty, K. S., Sueper, D., Kimmel, J. R., Worsnop, D. R., Trimborn, A., Northway, M., Stone, E. A., Schauer, J. J., Volkamer, R. M., Fortner, E., de Foy, B., Wang, J., Laskin, A., Shutthanandan, V., Zheng, J., Zhang, R., Gaffney, J., Marley, N. A., Paredes-Miranda, G., Arnott, W. P., Molina, L. T., Sosa, G., and Jimenez, J. L.: Mexico City aerosol analysis during MILAGRO using high resolution aerosol mass spectrometry at the urban supersite (T0) - Part 1: Fine particle composition and organic source apportionment, Atmos. Chem. Phys., 9, 6633-6653, doi:10.5194/acp-9-6633-2009, 2009.

Allan, J. D., Bower, K. N., Coe, H., Boudries, H., Jayne, J. T., Canagaratna, M. R., Millet, D. B., Goldstein, A. H., Quinn, P. K., Weber, R. J., and Worsnop, D. R.: Submicron aerosol composition at Trinidad Head, California, during ITCT 2K2: Its relationship with gas phase volatile organic carbon and assessment of instrument performance, J. Geophys. Res.-Atmos., 109, D23S24, doi:10.1029/2003JD004208, 2004.

Allan, J. D., Williams, P. I., Morgan, W. T., Martin, C. L., Flynn, M. J., Lee, J., Nemitz, E., Phillips, G. J., Gallagher, M. W., and Coe, H.: Contributions from transport, solid fuel burning and cooking to primary organic aerosols in two UK cities, Atmos. Chem. Phys., 10, 647-668, doi:10.5194/acp-10-647-2010, 2010. 
Andreae, M. O. and Gelencsér, A.: Black carbon or brown carbon? The nature of light-absorbing carbonaceous aerosols, Atmos. Chem. Phys., 6, 3131-3148, doi:10.5194/acp-6-3131-2006, 2006.

Bae, M. S., Schwab, J. J., Zhang, Q., Hogrefe, O., Demerjian, K. L., Weimer, S., Rhoads, K., Orsini, D., Venkatachari, P., and Hopke, P. K.: Interference of organic signals in highly time resolved nitrate measurements by low mass resolution aerosol mass spectrometry, J. Geophys. Res.-Atmos., 112, D22305, doi:10.1029/2007jd008614, 2007.

Bahreini, R., Ervens, B., Middlebrook, A. M., Warneke, C., de Gouw, J. A., DeCarlo, P. F., Jimenez, J. L., Brock, C. A., Neuman, J. A., Ryerson, T. B., Stark, H., Atlas, E., Brioude, J., Fried, A., Holloway, J. S., Peischl, J., Richter, D., Walega, J., Weibring, P., Wollny, A. G., and Fehsenfeld, F. C.: Organic aerosol formation in urban and industrial plumes near Houston and Dallas, Texas, J. Geophys. Res.-Atmos., 114, D00F16, doi:10.1029/2008JD011493, 2009.

Beddows, D. C. S., Harrison, R. M., Green, D. C., and Fuller, G. W.: Receptor modelling of both particle composition and size distribution from a background site in London, UK, Atmos. Chem. Phys. Discuss., 15, 10123-10162, doi:10.5194/acpd-15-101232015, 2015.

Blanchard, C. L., Hidy, G. M., Tanenbaum, S., Edgerton, E., Hartsell, B., and Jansen, J.: Carbon in southeastern U.S. aerosol particles: Empirical estimates of secondary organic aerosol formation, Atmos. Environ., 42, 6710-6720, doi:10.1016/j.atmosenv.2008.04.011, 2008.

Blanchard, C. L., Hidy, G. M., Tanenbaum, S., and Edgerton, E. S.: NMOC, ozone, and organic aerosol in the southeastern United States, 1999-2007: 3. Origins of organic aerosol in Atlanta, Georgia, and surrounding areas, Atmos. Environ., 45, 12911302, doi:10.1016/j.atmosenv.2010.12.004, 2011.

Blanchard, C. L., Hidy, G. M., Tanenbaum, S., Edgerton, E. S., and Hartsell, B. E.: The Southeastern Aerosol Research and Characterization (SEARCH) study: Spatial variations and chemical climatology, 1999-2010, J. Air Waste Manage., 63, 260-275, doi:10.1080/10962247.2012.749816, 2013.

Bougiatioti, A., Stavroulas, I., Kostenidou, E., Zarmpas, P., Theodosi, C., Kouvarakis, G., Canonaco, F., Prévôt, A. S. H., Nenes, A., Pandis, S. N., and Mihalopoulos, N.: Processing of biomassburning aerosol in the eastern Mediterranean during summertime, Atmos. Chem. Phys., 14, 4793-4807, doi:10.5194/acp-144793-2014, 2014.

Boyd, C. M., Sanchez, J., Xu, L., Eugene, A. J., Nah, T., Tuet, W. Y., Guzman, M. I., and Ng, N. L.: Secondary Organic Aerosol (SOA) formation from the $\beta$-pinene $+\mathrm{NO}_{3}$ system: effect of humidity and peroxy radical fate, Atmos. Chem. Phys. Discuss., 15, 26792744, doi:10.5194/acpd-15-2679-2015, 2015.

Bruns, E. A., Perraud, V., Zelenyuk, A., Ezell, M. J., Johnson, S. N., Yu, Y., Imre, D., Finlayson-Pitts, B. J., and Alexander, M. L.: Comparison of FTIR and Particle Mass Spectrometry for the Measurement of Particulate Organic Nitrates, Environ. Sci. Technol., 44, 1056-1061, doi:10.1021/es9029864, 2010.

Budisulistiorini, S. H., Canagaratna, M. R., Croteau, P. L., Marth, W. J., Baumann, K., Edgerton, E. S., Shaw, S. L., Knipping, E. M., Worsnop, D. R., Jayne, J. T., Gold, A., and Surratt, J. D.: Real-Time Continuous Characterization of Secondary Organic Aerosol Derived from Isoprene Epoxydiols in Down- town Atlanta, Georgia, Using the Aerodyne Aerosol Chemical Speciation Monitor, Environ. Sci. Technol., 47, 5686-5694, doi:10.1021/Es400023n, 2013.

Canagaratna, M. R., Jayne, J. T., Jimenez, J. L., Allan, J. D., Alfarra, M. R., Zhang, Q., Onasch, T. B., Drewnick, F., Coe, H., Middlebrook, A., Delia, A., Williams, L. R., Trimborn, A. M., Northway, M. J., DeCarlo, P. F., Kolb, C. E., Davidovits, P., and Worsnop, D. R.: Chemical and microphysical characterization of ambient aerosols with the aerodyne aerosol mass spectrometer, Mass Spectr. Rev., 26, 185-222, doi:10.1002/mas.20115, 2007.

Canagaratna, M. R., Jimenez, J. L., Kroll, J. H., Chen, Q., Kessler, S. H., Massoli, P., Hildebrandt Ruiz, L., Fortner, E., Williams, L. R., Wilson, K. R., Surratt, J. D., Donahue, N. M., Jayne, J. T., and Worsnop, D. R.: Elemental ratio measurements of organic compounds using aerosol mass spectrometry: characterization, improved calibration, and implications, Atmos. Chem. Phys., 15, 253-272, doi:10.5194/acp-15-253-2015, 2015.

Chen, Q., Farmer, D. K., Rizzo, L. V., Pauliquevis, T., Kuwata, M., Karl, T. G., Guenther, A., Allan, J. D., Coe, H., Andreae, M. O., Pöschl, U., Jimenez, J. L., Artaxo, P., and Martin, S. T.: Finemode organic mass concentrations and sources in the Amazonian wet season (AMAZE-08), Atmos. Chem. Phys. Discuss., 14, 16151-16186, doi:10.5194/acpd-14-16151-2014, 2014.

Cohan, D., Boylan, J., Marmur, A., and Khan, M.: An Integrated Framework for Multipollutant Air Quality Management and Its Application in Georgia, Environ. Manage., 40, 545-554, doi:10.1007/s00267-006-0228-4, 2007.

Crippa, M., DeCarlo, P. F., Slowik, J. G., Mohr, C., Heringa, M. F., Chirico, R., Poulain, L., Freutel, F., Sciare, J., Cozic, J., Di Marco, C. F., Elsasser, M., Nicolas, J. B., Marchand, N., Abidi, E., Wiedensohler, A., Drewnick, F., Schneider, J., Borrmann, S., Nemitz, E., Zimmermann, R., Jaffrezo, J.-L., Prévôt, A. S. H., and Baltensperger, U.: Wintertime aerosol chemical composition and source apportionment of the organic fraction in the metropolitan area of Paris, Atmos. Chem. Phys., 13, 961-981, doi:10.5194/acp-13-961-2013, 2013.

Crippa, M., Canonaco, F., Lanz, V. A., Äijälä, M., Allan, J. D., Carbone, S., Capes, G., Ceburnis, D., Dall'Osto, M., Day, D. A., DeCarlo, P. F., Ehn, M., Eriksson, A., Freney, E., Hildebrandt Ruiz, L., Hillamo, R., Jimenez, J. L., Junninen, H., Kiendler-Scharr, A., Kortelainen, A.-M., Kulmala, M., Laaksonen, A., Mensah, A. A., Mohr, C., Nemitz, E., O’Dowd, C., Ovadnevaite, J., Pandis, S. N., Petäjä, T., Poulain, L., Saarikoski, S., Sellegri, K., Swietlicki, E., Tiitta, P., Worsnop, D. R., Baltensperger, U., and Prévôt, A. S. H.: Organic aerosol components derived from 25 AMS data sets across Europe using a consistent ME-2 based source apportionment approach, Atmos. Chem. Phys., 14, 61596176, doi:10.5194/acp-14-6159-2014, 2014.

Day, D. A., Wooldridge, P. J., Dillon, M. B., Thornton, J. A., and Cohen, R. C.: A thermal dissociation laser-induced fluorescence instrument for in situ detection of NO2, peroxy nitrates, alkyl nitrates, and HNO3, J. Geophys. Res.-Atmos., 107, ACH 4-1ACH 4-14, doi:10.1029/2001JD000779, 2002.

DeCarlo, P. F., Kimmel, J. R., Trimborn, A., Northway, M. J., Jayne, J. T., Aiken, A. C., Gonin, M., Fuhrer, K., Horvath, T., Docherty, K. S., Worsnop, D. R., and Jimenez, J. L.: Field-Deployable, High-Resolution, Time-of-Flight Aerosol Mass Spectrometer, Anal. Chem., 78, 8281-8289, doi:10.1021/ac061249n, 2006. 
DeWitt, H. L., Hellebust, S., Temime-Roussel, B., Ravier, S., Polo, L., Jacob, V., Buisson, C., Charron, A., André, M., Pasquier, A., Besombes, J. L., Jaffrezo, J. L., Wortham, H., and Marchand, N.: Near-highway aerosol and gas-phase measurements in a high-diesel environment, Atmos. Chem. Phys., 15, 4373-4387, doi:10.5194/acp-15-4373-2015, 2015.

Eddingsaas, N. C., VanderVelde, D. G., and Wennberg, P. O.: Kinetics and Products of the Acid-Catalyzed Ring-Opening of Atmospherically Relevant Butyl Epoxy Alcohols, J. Phys. Chem. A, 114, 8106-8113, doi:10.1021/Jp103907c, 2010.

Edgerton, E. S., Hartsell, B. E., Saylor, R. D., Jansen, J. J., Hansen, D. A., and Hidy, G. M.: The southeastern aerosol research and characterization study: Part II. Filter-based measurements of fine and coarse particulate matter mass and composition, J. Air Waste Manage., 55, 1527-1542, 2005.

Ehn, M., Thornton, J. A., Kleist, E., Sipila, M., Junninen, H., Pullinen, I., Springer, M., Rubach, F., Tillmann, R., Lee, B., LopezHilfiker, F., Andres, S., Acir, I.-H., Rissanen, M., Jokinen, T., Schobesberger, S., Kangasluoma, J., Kontkanen, J., Nieminen, T., Kurten, T., Nielsen, L. B., Jorgensen, S., Kjaergaard, H. G., Canagaratna, M., Maso, M. D., Berndt, T., Petaja, T., Wahner, A., Kerminen, V.-M., Kulmala, M., Worsnop, D. R., Wildt, J., and Mentel, T. F.: A large source of low-volatility secondary organic aerosol, Nature, 506, 476-479, doi:10.1038/nature13032, 2014.

El Haddad, I., D’Anna, B., Temime-Roussel, B., Nicolas, M., Boreave, A., Favez, O., Voisin, D., Sciare, J., George, C., Jaffrezo, J.-L., Wortham, H., and Marchand, N.: Towards a better understanding of the origins, chemical composition and aging of oxygenated organic aerosols: case study of a Mediterranean industrialized environment, Marseille, Atmos. Chem. Phys., 13, 78757894, doi:10.5194/acp-13-7875-2013, 2013.

Farmer, D. K., Matsunaga, A., Docherty, K. S., Surratt, J. D., Seinfeld, J. H., Ziemann, P. J., and Jimenez, J. L.: Response of an aerosol mass spectrometer to organonitrates and organosulfates and implications for atmospheric chemistry, Proc. Natl. Acad. Sci., 107, 6670-6675, doi:10.1073/pnas.0912340107, 2010.

Feng, Y., Ramanathan, V., and Kotamarthi, V. R.: Brown carbon: a significant atmospheric absorber of solar radiation?, Atmos. Chem. Phys., 13, 8607-8621, doi:10.5194/acp-13-8607-2013, 2013

Ford, B. and Heald, C. L.: Aerosol loading in the Southeastern United States: reconciling surface and satellite observations, Atmos. Chem. Phys., 13, 9269-9283, doi:10.5194/acp-13-92692013, 2013.

Fry, J. L., Kiendler-Scharr, A., Rollins, A. W., Wooldridge, P. J., Brown, S. S., Fuchs, H., Dubé, W., Mensah, A., dal Maso, M., Tillmann, R., Dorn, H.-P., Brauers, T., and Cohen, R. C.: Organic nitrate and secondary organic aerosol yield from $\mathrm{NO}_{3}$ oxidation of $\beta$-pinene evaluated using a gas-phase kinetics/aerosol partitioning model, Atmos. Chem. Phys., 9, 1431-1449, doi:10.5194/acp-9-1431-2009, 2009.

Fry, J. L., Draper, D. C., Zarzana, K. J., Campuzano-Jost, P., Day, D. A., Jimenez, J. L., Brown, S. S., Cohen, R. C., Kaser, L., Hansel, A., Cappellin, L., Karl, T., Hodzic Roux, A., Turnipseed, A., Cantrell, C., Lefer, B. L., and Grossberg, N.: Observations of gas- and aerosol-phase organic nitrates at BEACHON-RoMBAS 2011, Atmos. Chem. Phys., 13, 8585-8605, doi:10.5194/acp-138585-2013, 2013.
Gaston, C. J., Riedel, T. P., Zhang, Z., Gold, A., Surratt, J. D., and Thornton, J. A.: Reactive Uptake of an Isoprene-Derived Epoxydiol to Submicron Aerosol Particles, Environ. Sci. Technol., 48, 11178-11186, doi:10.1021/es5034266, 2014.

Geron, C., Rasmussen, R., Arnts, R. R., and Guenther, A.: A review and synthesis of monoterpene speciation from forests in the United States, Atmos. Environ., 34, 1761-1781, doi:10.1016/S1352-2310(99)00364-7, 2000.

Grieshop, A. P., Donahue, N. M., and Robinson, A. L.: Laboratory investigation of photochemical oxidation of organic aerosol from wood fires 2: analysis of aerosol mass spectrometer data, Atmos. Chem. Phys., 9, 2227-2240, doi:10.5194/acp-9-2227-2009, 2009.

Guenther, A., Karl, T., Harley, P., Wiedinmyer, C., Palmer, P. I., and Geron, C.: Estimates of global terrestrial isoprene emissions using MEGAN (Model of Emissions of Gases and Aerosols from Nature), Atmos. Chem. Phys., 6, 3181-3210, doi:10.5194/acp-63181-2006, 2006.

Guo, H., Xu, L., Bougiatioti, A., Cerully, K. M., Capps, S. L., Hite Jr., J. R., Carlton, A. G., Lee, S.-H., Bergin, M. H., Ng, N. L., Nenes, A., and Weber, R. J.: Fine-particle water and $\mathrm{pH}$ in the southeastern United States, Atmos. Chem. Phys., 15, 5211-5228, doi:10.5194/acp-15-5211-2015, 2015.

Hansen, D. A., Edgerton, E. S., Hartsell, B. E., Jansen, J. J., Kandasamy, N., Hidy, G. M., and Blanchard, C. L.: The southeastern aerosol research and characterization study: Part 1 - overview, J. Air Waste Manage., 53, 1460-1471, 2003.

Hao, L. Q., Kortelainen, A., Romakkaniemi, S., Portin, H., Jaatinen, A., Leskinen, A., Komppula, M., Miettinen, P., Sueper, D., Pajunoja, A., Smith, J. N., Lehtinen, K. E. J., Worsnop, D. R., Laaksonen, A., and Virtanen, A.: Atmospheric submicron aerosol composition and particulate organic nitrate formation in a boreal forestland-urban mixed region, Atmos. Chem. Phys., 14, 13483 13495, doi:10.5194/acp-14-13483-2014, 2014.

Hayes, P. L., Ortega, A. M., Cubison, M. J., Froyd, K. D., Zhao, Y., Cliff, S. S., Hu, W. W., Toohey, D. W., Flynn, J. H., Lefer, B. L., Grossberg, N., Alvarez, S., Rappenglueck, B., Taylor, J. W., Allan, J. D., Holloway, J. S., Gilman, J. B., Kuster, W. C., De Gouw, J. A., Massoli, P., Zhang, X., Liu, J., Weber, R. J., Corrigan, A. L., Russell, L. M., Isaacman, G., Worton, D. R., Kreisberg, N. M., Goldstein, A. H., Thalman, R., Waxman, E. M., Volkamer, R., Lin, Y. H., Surratt, J. D., Kleindienst, T. E., Offenberg, J. H., Dusanter, S., Griffith, S., Stevens, P. S., Brioude, J., Angevine, W. M., and Jimenez, J. L.: Organic aerosol composition and sources in Pasadena, California, during the 2010 CalNex campaign, J. Geophys. Res.-Atmos., 118, 9233-9257, doi:10.1002/Jgrd.50530, 2013.

Hecobian, A., Zhang, X., Zheng, M., Frank, N., Edgerton, E. S., and Weber, R. J.: Water-Soluble Organic Aerosol material and the light-absorption characteristics of aqueous extracts measured over the Southeastern United States, Atmos. Chem. Phys., 10, 5965-5977, doi:10.5194/acp-10-5965-2010, 2010.

Hennigan, C. J., Sullivan, A. P., Fountoukis, C. I., Nenes, A., Hecobian, A., Vargas, O., Peltier, R. E., Case Hanks, A. T., Huey, L. G., Lefer, B. L., Russell, A. G., and Weber, R. J.: On the volatility and production mechanisms of newly formed nitrate and water soluble organic aerosol in Mexico City, Atmos. Chem. Phys., 8, 3761-3768, doi:10.5194/acp-8-3761-2008, 2008. 
Hennigan, C. J., Bergin, M. H., Russell, A. G., Nenes, A., and Weber, R. J.: Gas/particle partitioning of water-soluble organic aerosol in Atlanta, Atmos. Chem. Phys., 9, 3613-3628, doi:10.5194/acp-9-3613-2009, 2009.

Hennigan, C. J., Miracolo, M. A., Engelhart, G. J., May, A. A., Presto, A. A., Lee, T., Sullivan, A. P., McMeeking, G. R., Coe, H., Wold, C. E., Hao, W.-M., Gilman, J. B., Kuster, W. C., de Gouw, J., Schichtel, B. A., Collett Jr., J. L., Kreidenweis, S. M., and Robinson, A. L.: Chemical and physical transformations of organic aerosol from the photo-oxidation of open biomass burning emissions in an environmental chamber, Atmos. Chem. Phys., 11, 7669-7686, doi:10.5194/acp-11-7669-2011, 2011.

Heringa, M. F., DeCarlo, P. F., Chirico, R., Tritscher, T., Dommen, J., Weingartner, E., Richter, R., Wehrle, G., Prévôt, A. S. H., and Baltensperger, U.: Investigations of primary and secondary particulate matter of different wood combustion appliances with a high-resolution time-of-flight aerosol mass spectrometer, Atmos. Chem. Phys., 11, 5945-5957, doi:10.5194/acp-11-59452011, 2011.

Hidy, G. M., Blanchard, C. L., Baumann, K., Edgerton, E., Tanenbaum, S., Shaw, S., Knipping, E., Tombach, I., Jansen, J., and Walters, J.: Chemical climatology of the southeastern United States, 1999-2013, Atmos. Chem. Phys., 14, 11893-11914, doi:10.5194/acp-14-11893-2014, 2014.

Hildebrandt, L., Engelhart, G. J., Mohr, C., Kostenidou, E., Lanz, V. A., Bougiatioti, A., DeCarlo, P. F., Prevot, A. S. H., Baltensperger, U., Mihalopoulos, N., Donahue, N. M., and Pandis, S. N.: Aged organic aerosol in the Eastern Mediterranean: the Finokalia Aerosol Measurement Experiment - 2008, Atmos. Chem. Phys., 10, 4167-4186, doi:10.5194/acp-10-4167-2010, 2010.

Hu, W. W., Campuzano-Jost, P., Palm, B. B., Day, D. A., Ortega, A. M., Hayes, P. L., Krechmer, J. E., Chen, Q., Kuwata, M., Liu, Y. J., de Sá, S. S., Martin, S. T., Hu, M., Budisulistiorini, S. H., Riva, M., Surratt, J. D., St. Clair, J. M., Isaacman-Van Wertz, G., Yee, L. D., Goldstein, A. H., Carbone, S., Artaxo, P., de Gouw, J. A., Koss, A., Wisthaler, A., Mikoviny, T., Karl, T., Kaser, L., Jud, W., Hansel, A., Docherty, K. S., Robinson, N. H., Coe, H., Allan, J. D., Canagaratna, M. R., Paulot, F., and Jimenez, J. L.: Characterization of a real-time tracer for Isoprene Epoxydiolsderived Secondary Organic Aerosol (IEPOX-SOA) from aerosol mass spectrometer measurements, Atmos. Chem. Phys. Discuss., 15, 11223-11276, doi:10.5194/acpd-15-11223-2015, 2015.

Huang, X.-F., He, L.-Y., Hu, M., Canagaratna, M. R., Sun, Y., Zhang, Q., Zhu, T., Xue, L., Zeng, L.-W., Liu, X.-G., Zhang, Y.-H., Jayne, J. T., Ng, N. L., and Worsnop, D. R.: Highly time-resolved chemical characterization of atmospheric submicron particles during 2008 Beijing Olympic Games using an Aerodyne High-Resolution Aerosol Mass Spectrometer, Atmos. Chem. Phys., 10, 8933-8945, doi:10.5194/acp-10-8933-2010, 2010.

Huffman, J. A., Docherty, K. S., Aiken, A. C., Cubison, M. J., U1brich, I. M., DeCarlo, P. F., Sueper, D., Jayne, J. T., Worsnop, D. R., Ziemann, P. J., and Jimenez, J. L.: Chemically-resolved aerosol volatility measurements from two megacity field studies, Atmos. Chem. Phys., 9, 7161-7182, doi:10.5194/acp-9-71612009, 2009.

Isaacman, G., Kreisberg, N. M., Yee, L. D., Worton, D. R., Chan, A. W. H., Moss, J. A., Hering, S. V., and Goldstein, A.
H.: Online derivatization for hourly measurements of gas- and particle-phase semi-volatile oxygenated organic compounds by thermal desorption aerosol gas chromatography (SV-TAG), Atmos. Meas. Tech., 7, 4417-4429, doi:10.5194/amt-7-4417-2014, 2014.

Jacobs, M. I., Burke, W. J., and Elrod, M. J.: Kinetics of the reactions of isoprene-derived hydroxynitrates: gas phase epoxide formation and solution phase hydrolysis, Atmos. Chem. Phys., 14, 8933-8946, doi:10.5194/acp-14-8933-2014, 2014.

Jaeckels, J. M., Bae, M.-S., and Schauer, J. J.: Positive Matrix Factorization (PMF) Analysis of Molecular Marker Measurements to Quantify the Sources of Organic Aerosols, Environ. Sci. Technol., 41, 5763-5769, doi:10.1021/es062536b, 2007.

Janssen, R. H. H., Vilà-Guerau de Arellano, J., Jimenez, J. L., Ganzeveld, L. N., Robinson, N. H., Allan, J. D., Coe, H., and Pugh, T. A. M.: Influence of boundary layer dynamics and isoprene chemistry on the organic aerosol budget in a tropical forest, J. Geophys. Res.-Atmos., 118, 9351-9366, doi:10.1002/jgrd.50672, 2013.

Jathar, S. H., Gordon, T. D., Hennigan, C. J., Pye, H. O. T., Pouliot, G., Adams, P. J., Donahue, N. M., and Robinson, A. L.: Unspeciated organic emissions from combustion sources and their influence on the secondary organic aerosol budget in the United States, Proc. Natl. Acad. Sci. USA, 111, 10473-10478, doi:10.1073/pnas.1323740111, 2014.

Jayne, J. T., Leard, D. C., Zhang, X. F., Davidovits, P., Smith, K. A., Kolb, C. E., and Worsnop, D. R.: Development of an aerosol mass spectrometer for size and composition analysis of submicron particles, Aerosol Sci. Tech., 33, 49-70, doi:10.1080/027868200410840, 2000.

Jimenez, J. L., Canagaratna, M. R., Donahue, N. M., Prevot, A. S. H., Zhang, Q., Kroll, J. H., DeCarlo, P. F., Allan, J. D., Coe, H., Ng, N. L., Aiken, A. C., Docherty, K. S., Ulbrich, I. M., Grieshop, A. P., Robinson, A. L., Duplissy, J., Smith, J. D., Wilson, K. R., Lanz, V. A., Hueglin, C., Sun, Y. L., Tian, J., Laaksonen, A., Raatikainen, T., Rautiainen, J., Vaattovaara, P., Ehn, M., Kulmala, M., Tomlinson, J. M., Collins, D. R., Cubison, M. J., Dunlea, E. J., Huffman, J. A., Onasch, T. B., Alfarra, M. R., Williams, P. I., Bower, K., Kondo, Y., Schneider, J., Drewnick, F., Borrmann, S., Weimer, S., Demerjian, K., Salcedo, D., Cottrell, L., Griffin, R., Takami, A., Miyoshi, T., Hatakeyama, S., Shimono, A., Sun, J. Y., Zhang, Y. M., Dzepina, K., Kimmel, J. R., Sueper, D., Jayne, J. T., Herndon, S. C., Trimborn, A. M., Williams, L. R., Wood, E. C., Middlebrook, A. M., Kolb, C. E., Baltensperger, U., and Worsnop, D. R.: Evolution of Organic Aerosols in the Atmosphere, Science, 326, 1525-1529, doi:10.1126/science.1180353, 2009.

Kroll, J. H., Ng, N. L., Murphy, S. M., Flagan, R. C., and Seinfeld, J. H.: Secondary organic aerosol formation from isoprene photooxidation, Environ. Sci. Technol., 40, 1869-1877, doi:10.1021/Es0524301, 2006.

Kroll, J. H., Donahue, N. M., Jimenez, J. L., Kessler, S. H., Canagaratna, M. R., Wilson, K. R., Altieri, K. E., Mazzoleni, L. R., Wozniak, A. S., Bluhm, H., Mysak, E. R., Smith, J. D., Kolb, C. E., and Worsnop, D. R.: Carbon oxidation state as a metric for describing the chemistry of atmospheric organic aerosol, Nat. Chem., 3, 133-139, doi:10.1038/Nchem.948, 2011.

Lack, D. A., Bahreini, R., Langridge, J. M., Gilman, J. B., and Middlebrook, A. M.: Brown carbon absorption linked to organic 
mass tracers in biomass burning particles, Atmos. Chem. Phys., 13, 2415-2422, doi:10.5194/acp-13-2415-2013, 2013.

Lanz, V. A., Alfarra, M. R., Baltensperger, U., Buchmann, B., Hueglin, C., and Prévôt, A. S. H.: Source apportionment of submicron organic aerosols at an urban site by factor analytical modelling of aerosol mass spectra, Atmos. Chem. Phys., 7, 15031522, doi:10.5194/acp-7-1503-2007, 2007.

Li, Y. J., Lee, B. P., Su, L., Fung, J. C. H., and Chan, C.K.: Seasonal characteristics of fine particulate matter (PM) based on highresolution time-of-flight aerosol mass spectrometric (HR-ToFAMS) measurements at the HKUST Supersite in Hong Kong, Atmos. Chem. Phys., 15, 37-53, doi:10.5194/acp-15-37-2015, 2015.

Lim, H.-J. and Turpin, B. J.: Origins of Primary and Secondary Organic Aerosol in Atlanta: Results of Time-Resolved Measurements during the Atlanta Supersite Experiment, Environ. Sci. Technol., 36, 4489-4496, doi:10.1021/es0206487, 2002.

Lin, Y. H., Zhang, Z. F., Docherty, K. S., Zhang, H. F., Budisulistiorini, S. H., Rubitschun, C. L., Shaw, S. L., Knipping, E. M., Edgerton, E. S., Kleindienst, T. E., Gold, A., and Surratt, J. D.: Isoprene Epoxydiols as Precursors to Secondary Organic Aerosol Formation: Acid-Catalyzed Reactive Uptake Studies with Authentic Compounds, Environ. Sci. Technol., 46, 250258, doi:10.1021/Es202554c, 2012.

Lin, Y.-H., Budisulistiorini, S. H., Chu, K., Siejack, R. A., Zhang, H., Riva, M., Zhang, Z., Gold, A., Kautzman, K. E., and Surratt, J. D.: Light-Absorbing Oligomer Formation in Secondary Organic Aerosol from Reactive Uptake of Isoprene Epoxydiols, Environ. Sci. Technol., 48, 12012-12021, doi:10.1021/es503142b, 2014.

Liu, J., Scheuer, E., Dibb, J., Ziemba, L. D., Thornhill, K. L., Anderson, B. E., Wisthaler, A., Mikoviny, T., Devi, J. J., Bergin, M., and Weber, R. J.: Brown carbon in the continental troposphere, Geophys. Res. Lett., 41, 2013GL058976, doi:10.1002/2013GL058976, 2014.

Liu, S., Day, D. A., Shields, J. E., and Russell, L. M.: Ozone-driven daytime formation of secondary organic aerosol containing carboxylic acid groups and alkane groups, Atmos. Chem. Phys., 11, 8321-8341, doi:10.5194/acp-11-8321-2011, 2011.

Liu, Y., Kuwata, M., Strick, B. F., Geiger, F. M., Thomson, R. J., McKinney, K. A., and Martin, S. T.: Uptake of Epoxydiol Isomers Accounts for Half of the Particle-Phase Material Produced from Isoprene Photooxidation via the $\mathrm{HO} 2$ Pathway, Environ. Sci. Technol., 49, 250-258, doi:10.1021/es5034298, 2015.

Mao, J., Ren, X., Zhang, L., Van Duin, D. M., Cohen, R. C., Park, J.-H., Goldstein, A. H., Paulot, F., Beaver, M. R., Crounse, J. D., Wennberg, P. O., DiGangi, J. P., Henry, S. B., Keutsch, F. N., Park, C., Schade, G. W., Wolfe, G. M., Thornton, J. A., and Brune, W. H.: Insights into hydroxyl measurements and atmospheric oxidation in a California forest, Atmos. Chem. Phys., 12, 8009-8020, doi:10.5194/acp-12-8009-2012, 2012.

Matthew, B. M., Middlebrook, A. M., and Onasch, T. B.: Collection efficiencies in an Aerodyne Aerosol Mass Spectrometer as a function of particle phase for laboratory generated aerosols, Aerosol Sci. Tech., 42, 884-898, doi:10.1080/02786820802356797, 2008.

May, A. A., Saleh, R., Hennigan, C. J., Donahue, N. M., and Robinson, A. L.: Volatility of Organic Molecular Markers Used for Source Apportionment Analysis: Measurements and Impli- cations for Atmospheric Lifetime, Environ. Sci. Technol., 46, 12435-12444, doi:10.1021/es302276t, 2012.

Middlebrook, A. M., Bahreini, R., Jimenez, J. L., and Canagaratna, M. R.: Evaluation of Composition-Dependent Collection Efficiencies for the Aerodyne Aerosol Mass Spectrometer using Field Data, Aerosol Sci. Tech., 46, 258-271, doi:10.1080/02786826.2011.620041, 2012.

Mohr, C., Huffman, J. A., Cubison, M. J., Aiken, A. C., Docherty, K. S., Kimmel, J. R., Ulbrich, I. M., Hannigan, M., and Jimenez, J. L.: Characterization of Primary Organic Aerosol Emissions from Meat Cooking, Trash Burning, and Motor Vehicles with High-Resolution Aerosol Mass Spectrometry and Comparison with Ambient and Chamber Observations, Environ. Sci. Technol., 43, 2443-2449, doi:10.1021/es8011518, 2009.

Mohr, C., DeCarlo, P. F., Heringa, M. F., Chirico, R., Slowik, J. G., Richter, R., Reche, C., Alastuey, A., Querol, X., Seco, R., Peñuelas, J., Jiménez, J. L., Crippa, M., Zimmermann, R., Baltensperger, U., and Prévôt, A. S. H.: Identification and quantification of organic aerosol from cooking and other sources in Barcelona using aerosol mass spectrometer data, Atmos. Chem. Phys., 12, 1649-1665, doi:10.5194/acp-12-1649-2012, 2012.

Ng, N. L., Canagaratna, M. R., Zhang, Q., Jimenez, J. L., Tian, J., Ulbrich, I. M., Kroll, J. H., Docherty, K. S., Chhabra, P. S., Bahreini, R., Murphy, S. M., Seinfeld, J. H., Hildebrandt, L., Donahue, N. M., DeCarlo, P. F., Lanz, V. A., Prévôt, A. S. H., Dinar, E., Rudich, Y., and Worsnop, D. R.: Organic aerosol components observed in Northern Hemispheric datasets from Aerosol Mass Spectrometry, Atmos. Chem. Phys., 10, 46254641, doi:10.5194/acp-10-4625-2010, 2010.

Ng, N. L., Herndon, S. C., Trimborn, A., Canagaratna, M. R., Croteau, P. L., Onasch, T. B., Sueper, D., Worsnop, D. R., Zhang, Q., Sun, Y. L., and Jayne, J. T.: An Aerosol Chemical Speciation Monitor (ACSM) for Routine Monitoring of the Composition and Mass Concentrations of Ambient Aerosol, Aerosol Sci. Tech., 45, 780-794, doi:10.1080/02786826.2011.560211, 2011.

Nguyen, T. B., Coggon, M. M., Bates, K. H., Zhang, X., Schwantes, R. H., Schilling, K. A., Loza, C. L., Flagan, R. C., Wennberg, P. O., and Seinfeld, J. H.: Organic aerosol formation from the reactive uptake of isoprene epoxydiols (IEPOX) onto nonacidified inorganic seeds, Atmos. Chem. Phys., 14, 3497-3510, doi:10.5194/acp-14-3497-2014, 2014.

Nordin, E. Z., Eriksson, A. C., Roldin, P., Nilsson, P. T., Carlsson, J. E., Kajos, M. K., Hellén, H., Wittbom, C., Rissler, J., Löndahl, J., Swietlicki, E., Svenningsson, B., Bohgard, M., Kulmala, M., Hallquist, M., and Pagels, J. H.: Secondary organic aerosol formation from idling gasoline passenger vehicle emissions investigated in a smog chamber, Atmos. Chem. Phys., 13, 6101-6116, doi:10.5194/acp-13-6101-2013, 2013.

Orsini, D. A., Ma, Y. L., Sullivan, A., Sierau, B., Baumann, K., and Weber, R. J.: Refinements to the particle-into-liquid sampler (PILS) for ground and airborne measurements of water soluble aerosol composition, Atmos. Environ., 37, 1243-1259, doi:10.1016/S1352-2310(02)01015-4, 2003.

Paatero, P.: A weighted non-negative least squares algorithm for three-way "PARAFAC" factor analysis, Chemometr. Intell. Lab., 38, 223-242, doi:10.1016/S0169-7439(97)00031-2, 1997.

Paatero, P. and Tapper, U.: Positive Matrix Factorization a Nonnegative Factor Model with Optimal Utilization of 
Error-Estimates of Data Values, Environmetrics, 5, 111-126, doi:10.1002/env.3170050203, 1994.

Paglione, M., Kiendler-Scharr, A., Mensah, A. A., Finessi, E., Giulianelli, L., Sandrini, S., Facchini, M. C., Fuzzi, S., Schlag, P., Piazzalunga, A., Tagliavini, E., Henzing, J. S., and Decesari, S.: Identification of humic-like substances (HULIS) in oxygenated organic aerosols using NMR and AMS factor analyses and liquid chromatographic techniques, Atmos. Chem. Phys., 14, 2545, doi:10.5194/acp-14-25-2014, 2014.

Paulot, F., Crounse, J. D., Kjaergaard, H. G., Kurten, A., St Clair, J. M., Seinfeld, J. H., and Wennberg, P. O.: Unexpected Epoxide Formation in the Gas-Phase Photooxidation of Isoprene, Science, 325, 730-733, doi:10.1126/science.1172910, 2009.

Perring, A. E., Pusede, S. E., and Cohen, R. C.: An Observational Perspective on the Atmospheric Impacts of Alkyl and Multifunctional Nitrates on Ozone and Secondary Organic Aerosol, Chem. Rev., 113, 5848-5870, doi:10.1021/Cr300520x, 2013.

Piletic, I. R., Edney, E. O., and Bartolotti, L. J.: A computational study of acid catalyzed aerosol reactions of atmospherically relevant epoxides, Phys. Chem. Chem. Phys., 15, 18065-18076, doi:10.1039/C3CP52851K, 2013.

Platt, S. M., El Haddad, I., Zardini, A. A., Clairotte, M., Astorga, C., Wolf, R., Slowik, J. G., Temime-Roussel, B., Marchand, N., Ježek, I., Drinovec, L., Močnik, G., Möhler, O., Richter, R., Barmet, P., Bianchi, F., Baltensperger, U., and Prévôt, A. S. H.: Secondary organic aerosol formation from gasoline vehicle emissions in a new mobile environmental reaction chamber, Atmos. Chem. Phys., 13, 9141-9158, doi:10.5194/acp-13-91412013, 2013.

Presto, A. A., Gordon, T. D., and Robinson, A. L.: Primary to secondary organic aerosol: evolution of organic emissions from mobile combustion sources, Atmos. Chem. Phys., 14, 5015-5036, doi:10.5194/acp-14-5015-2014, 2014.

Raatikainen, T., Vaattovaara, P., Tiitta, P., Miettinen, P., Rautiainen, J., Ehn, M., Kulmala, M., Laaksonen, A., and Worsnop, D. R.: Physicochemical properties and origin of organic groups detected in boreal forest using an aerosol mass spectrometer, Atmos. Chem. Phys., 10, 2063-2077, doi:10.5194/acp-10-20632010, 2010.

Robinson, A. L., Donahue, N. M., Shrivastava, M. K., Weitkamp, E. A., Sage, A. M., Grieshop, A. P., Lane, T. E., Pierce, J. R., and Pandis, S. N.: Rethinking organic aerosols: Semivolatile emissions and photochemical aging, Science, 315, 1259-1262, doi:10.1126/science.1133061, 2007.

Robinson, N. H., Hamilton, J. F., Allan, J. D., Langford, B., Oram, D. E., Chen, Q., Docherty, K., Farmer, D. K., Jimenez, J. L., Ward, M. W., Hewitt, C. N., Barley, M. H., Jenkin, M. E., Rickard, A. R., Martin, S. T., McFiggans, G., and Coe, H.: Evidence for a significant proportion of Secondary Organic Aerosol from isoprene above a maritime tropical forest, Atmos. Chem. Phys., 11, 1039-1050, doi:10.5194/acp-11-1039-2011, 2011a.

Robinson, N. H., Newton, H. M., Allan, J. D., Irwin, M., Hamilton, J. F., Flynn, M., Bower, K. N., Williams, P. I., Mills, G., Reeves, C. E., McFiggans, G., and Coe, H.: Source attribution of Bornean air masses by back trajectory analysis during the OP3 project, Atmos. Chem. Phys., 11, 9605-9630, doi:10.5194/acp-11-96052011, 2011b.

Rollins, A. W., Fry, J. L., Hunter, J. F., Kroll, J. H., Worsnop, D. R., Singaram, S. W., and Cohen, R. C.: Elemental analysis of aerosol organic nitrates with electron ionization high-resolution mass spectrometry, Atmos. Meas. Tech., 3, 301-310, doi:10.5194/amt3-301-2010, 2010.

Rollins, A. W., Browne, E. C., Min, K.-E., Pusede, S. E., Wooldridge, P. J., Gentner, D. R., Goldstein, A. H., Liu, S., Day, D. A., Russell, L. M., and Cohen, R. C.: Evidence for NOx Control over Nighttime SOA Formation, Science, 337, 1210-1212, doi:10.1126/science.1221520, 2012.

Russell, A., Holmes, H., Friberg, M., Ivey, C., Hu, Y., Balachandran, S., Mulholland, J., Tolbert, P., Sarnat, J., Sarnat, S., Strickland, M., Chang, H., and Liu, Y.: Use of Air Quality Modeling Results in Health Effects Research, in: Air Pollution Modeling and its Application XXIII, edited by: Steyn, D., and Mathur, R., Springer Proceedings in Complexity, Springer International Publishing, 1-5, 2014.

Sato, K., Takami, A., Isozaki, T., Hikida, T., Shimono, A., and Imamura, T.: Mass spectrometric study of secondary organic aerosol formed from the photo-oxidation of aromatic hydrocarbons, Atmos. Environ., 44, 1080-1087, doi:10.1016/j.atmosenv.2009.12.013, 2010.

Schichtel, B. A., Malm, W. C., Bench, G., Fallon, S., McDade, C. E., Chow, J. C., and Watson, J. G.: Fossil and contemporary fine particulate carbon fractions at 12 rural and urban sites in the United States, J. Geophys. Res.-Atmos., 113, D02311, doi:10.1029/2007JD008605, 2008.

Schneider, J., Weimer, S., Drewnick, F., Borrmann, S., Helas, G., Gwaze, P., Schmid, O., Andreae, M. O., and Kirchner, U.: Mass spectrometric analysis and aerodynamic properties of various types of combustion-related aerosol particles, Int. J. Mass Spectrom., 258, 37-49, doi:10.1016/j.ijms.2006.07.008, 2006.

Setyan, A., Zhang, Q., Merkel, M., Knighton, W. B., Sun, Y., Song, C., Shilling, J. E., Onasch, T. B., Herndon, S. C., Worsnop, D. R., Fast, J. D., Zaveri, R. A., Berg, L. K., Wiedensohler, A., Flowers, B. A., Dubey, M. K., and Subramanian, R.: Characterization of submicron particles influenced by mixed biogenic and anthropogenic emissions using high-resolution aerosol mass spectrometry: results from CARES, Atmos. Chem. Phys., 12, 8131-8156, doi:10.5194/acp-12-8131-2012, 2012.

Slowik, J. G., Vlasenko, A., McGuire, M., Evans, G. J., and Abbatt, J. P. D.: Simultaneous factor analysis of organic particle and gas mass spectra: AMS and PTR-MS measurements at an urban site, Atmos. Chem. Phys., 10, 1969-1988, doi:10.5194/acp-10-19692010, 2010.

Slowik, J. G., Brook, J., Chang, R. Y.-W., Evans, G. J., Hayden, K., Jeong, C.-H., Li, S.-M., Liggio, J., Liu, P. S. K., McGuire, M., Mihele, C., Sjostedt, S., Vlasenko, A., and Abbatt, J. P. D.: Photochemical processing of organic aerosol at nearby continental sites: contrast between urban plumes and regional aerosol, Atmos. Chem. Phys., 11, 2991-3006, doi:10.5194/acp-11-29912011, 2011.

Sun, Y. L., Zhang, Q., Schwab, J. J., Chen, W.-N., Bae, M.-S., Hung, H.-M., Lin, Y.-C., Ng, N. L., Jayne, J., Massoli, P., Williams, L. R., and Demerjian, K. L.: Characterization of near-highway submicron aerosols in New York City with a high-resolution aerosol mass spectrometer, Atmos. Chem. Phys., 12, 2215-2227, doi:10.5194/acp-12-2215-2012, 2012a.

Sun, Y. L., Zhang, Q., Schwab, J. J., Yang, T., Ng, N. L., and Demerjian, K. L.: Factor analysis of combined organic and inorganic aerosol mass spectra from high resolution aerosol mass spec- 
trometer measurements, Atmos. Chem. Phys., 12, 8537-8551, doi:10.5194/acp-12-8537-2012, 2012 b.

Surratt, J. D., Lewandowski, M., Offenberg, J. H., Jaoui, M., Kleindienst, T. E., Edney, E. O., and Seinfeld, J. H.: Effect of acidity on secondary organic aerosol formation from isoprene, Environ. Sci. Technol., 41, 5363-5369, doi:10.1021/Es0704176, 2007.

Tsigaridis, K., Daskalakis, N., Kanakidou, M., Adams, P. J., Artaxo, P., Bahadur, R., Balkanski, Y., Bauer, S. E., Bellouin, N., Benedetti, A., Bergman, T., Berntsen, T. K., Beukes, J. P., Bian, H., Carslaw, K. S., Chin, M., Curci, G., Diehl, T., Easter, R. C., Ghan, S. J., Gong, S. L., Hodzic, A., Hoyle, C. R., Iversen, T., Jathar, S., Jimenez, J. L., Kaiser, J. W., Kirkevåg, A., Koch, D., Kokkola, H., Lee, Y. H, Lin, G., Liu, X., Luo, G., Ma, X., Mann, G. W., Mihalopoulos, N., Morcrette, J.-J., Müller, J.-F., Myhre, G., Myriokefalitakis, S., Ng, N. L., O’Donnell, D., Penner, J. E., Pozzoli, L., Pringle, K. J., Russell, L. M., Schulz, M., Sciare, J., Seland, Ø., Shindell, D. T., Sillman, S., Skeie, R. B., Spracklen, D., Stavrakou, T., Steenrod, S. D., Takemura, T., Tiitta, P., Tilmes, S., Tost, H., van Noije, T., van Zyl, P. G., von Salzen, K., Yu, F., Wang, Z., Wang, Z., Zaveri, R. A., Zhang, H., Zhang, K., Zhang, Q., and Zhang, X.: The AeroCom evaluation and intercomparison of organic aerosol in global models, Atmos. Chem. Phys., 14, 10845-10895, doi:10.5194/acp-1410845-2014, 2014.

Ulbrich, I. M., Canagaratna, M. R., Zhang, Q., Worsnop, D. R., and Jimenez, J. L.: Interpretation of organic components from Positive Matrix Factorization of aerosol mass spectrometric data, Atmos. Chem. Phys., 9, 2891-2918, doi:10.5194/acp-9-2891-2009, 2009.

Verma, V., Fang, T., Guo, H., King, L., Bates, J. T., Peltier, R. E., Edgerton, E., Russell, A. G., and Weber, R. J.: Reactive oxygen species associated with water-soluble $\mathrm{PM}_{2.5}$ in the southeastern United States: spatiotemporal trends and source apportionment, Atmos. Chem. Phys., 14, 12915-12930, doi:10.5194/acp14-12915-2014, 2014.

Verma, V., Fang, T., Xu, L., Peltier, R. E., Russell, A. G., Ng, N. L., and Weber, R. J.: Organic Aerosols Associated with the Generation of Reactive Oxygen Species (ROS) by Water-Soluble $\mathrm{PM}_{2.5}$, Environ. Sci. Technol., 41, 4646-4656, doi:10.1021/es505577w, 2015.

Virkkula, A., Mäkelä, T., Hillamo, R., Yli-Tuomi, T., Hirsikko, A., Hämeri, K., and Koponen, I. K.: A Simple Procedure for Correcting Loading Effects of Aethalometer Data, J. Air Waste Manage., 57, 1214-1222, doi:10.3155/1047-3289.57.10.1214, 2007.

Visser, S., Slowik, J. G., Furger, M., Zotter, P., Bukowiecki, N., Canonaco, F., Flechsig, U., Appel, K., Green, D. C., Tremper, A. H., Young, D. E., Williams, P. I., Allan, J. D., Coe, H., Williams, L. R., Mohr, C., Xu, L., Ng, N. L., Nemitz, E., Barlow, J. F., Halios, C. H., Fleming, Z. L., Baltensperger, U., and Prévôt, A. S. H.: Advanced source apportionment of size-resolved trace elements at multiple sites in London during winter, Atmos. Chem. Phys. Discuss., 15, 14733-14781, doi:10.5194/acpd-15-147332015, 2015.

Washenfelder, R. A., Attwood, A. R., Brock, C. A., Guo, H., Xu, L., Weber, R. J., Ng, N. L., Allen, H. M., Ayres, B. R., Baumann, K., Cohen, R. C., Draper, D. C., Duffey, K. C., Edgerton, E., Fry, J. L., Hu, W. W., Jimenez, J. L., Palm, B. B., Romer, P., Stone, E. A., Wooldridge, P. J., and Brown, S. S.: Biomass burning dominates brown carbon absorption in the rural southeastern United States, Geophys. Res. Lett., 2014GL062444, doi:10.1002/2014GL062444, 2015.

Weber, R.: Short-Term Temporal Variation in PM2.5 Mass and Chemical Composition during the Atlanta Supersite Experiment, 1999, J. Air Waste Manage., 53, 84-91, doi:10.1080/10473289.2003.10466123, 2003.

Weber, R. J., Orsini, D., Daun, Y., Lee, Y. N., Klotz, P. J., and Brechtel, F.: A particle-into-liquid collector for rapid measurement of aerosol bulk chemical composition, Aerosol Sci. Tech., 35, 718727, doi:10.1080/02786820152546761, 2001.

Weber, R., Orsini, D., Duan, Y., Baumann, K., Kiang, C. S., Chameides, W., Lee, Y. N., Brechtel, F., Klotz, P., Jongejan, P., ten Brink, H., Slanina, J., Boring, C. B., Genfa, Z., Dasgupta, P., Hering, S., Stolzenburg, M., Dutcher, D. D., Edgerton, E., Hartsell, B., Solomon, P., and Tanner, R.: Intercomparison of near real time monitors of $\mathrm{PM}_{2.5}$ nitrate and sulfate at the U.S. Environmental Protection Agency Atlanta Supersite, J. Geophys. Res.-Atmos., 108, 8421, doi:10.1029/2001JD001220, 2003.

Weber, R. J., Sullivan, A. P., Peltier, R. E., Russell, A., Yan, B., Zheng, M., de Gouw, J., Warneke, C., Brock, C., Holloway, J. S., Atlas, E. L., and Edgerton, E.: A study of secondary organic aerosol formation in the anthropogenic-influenced southeastern United States, J. Geophys. Res.-Atmos., 112, D13302 doi:10.1029/2007jd008408, 2007.

Winquist, A., Kirrane, E., Klein, M., Strickland, M., Darrow, L. A., Sarnat, S. E., Gass, K., Mulholland, J., Russell, A., and Tolbert, P.: Joint Effects of Ambient Air Pollutants on Pediatric Asthma Emergency Department Visits in Atlanta, 1998-2004, Epidemiology, 25, 666-673, doi:10.1097/ede.0000000000000146, 2014.

Xu, L., Kollman, M. S., Song, C., Shilling, J. E., and Ng, N. L.: Effects of $\mathrm{NO}_{x}$ on the Volatility of Secondary Organic Aerosol from Isoprene Photooxidation, Environ. Sci. Technol., 48, 2253 2262, doi:10.1021/es404842g, 2014.

Xu, L., Guo, H., Boyd, C. M., Klein, M., Bougiatioti, A., Cerully, K. M., Hite, J. R., Isaacman-VanWertz, G., Kreisberg, N. M., Knote, C., Olson, K., Koss, A., Goldstein, A. H., Hering, S. V., de Gouw, J., Baumann, K., Lee, S.-H., Nenes, A., Weber, R. J., and $\mathrm{Ng}, \mathrm{N}$. L.: Effects of anthropogenic emissions on aerosol formation from isoprene and monoterpenes in the southeastern United States, Proc. Natl. Acad. Sci. USA, 112, 37-42, doi:10.1073/pnas.1417609112, 2015.

Zhang, Q., Alfarra, M. R., Worsnop, D. R., Allan, J. D., Coe, H., Canagaratna, M. R., and Jimenez, J. L.: Deconvolution and Quantification of Hydrocarbon-like and Oxygenated Organic Aerosols Based on Aerosol Mass Spectrometry, Environ. Sci. Technol., 39, 4938-4952, doi:10.1021/es0485681, 2005.

Zhang, Q., Jimenez, J. L., Canagaratna, M. R., Ulbrich, I. M., Ng, N. L., Worsnop, D. R., and Sun, Y. L.: Understanding atmospheric organic aerosols via factor analysis of aerosol mass spectrometry: a review, Anal. Bioanal. Chem., 401, 3045-3067, doi:10.1007/s00216-011-5355-y, 2011.

Zhang, X., Hecobian, A., Zheng, M., Frank, N. H., and Weber, R. J.: Biomass burning impact on $\mathrm{PM}_{2.5}$ over the southeastern US during 2007: integrating chemically speciated FRM filter measurements, MODIS fire counts and PMF analysis, Atmos. Chem. Phys., 10, 6839-6853, doi:10.5194/acp-10-6839-2010, 2010.

Zhang, X., Liu, Z., Hecobian, A., Zheng, M., Frank, N. H., Edgerton, E. S., and Weber, R. J.: Spatial and seasonal variations of fine particle water-soluble organic carbon (WSOC) over 
the southeastern United States: implications for secondary organic aerosol formation, Atmos. Chem. Phys., 12, 6593-6607, doi:10.5194/acp-12-6593-2012, 2012.

Zhao, R., Mungall, E. L., Lee, A. K. Y., Aljawhary, D., and Abbatt, J. P. D.: Aqueous-phase photooxidation of levoglucosan a mechanistic study using aerosol time-of-flight chemical ionization mass spectrometry (Aerosol ToF-CIMS), Atmos. Chem. Phys., 14, 9695-9706, doi:10.5194/acp-14-9695-2014, 2014.

Zheng, M., Cass, G. R., Schauer, J. J., and Edgerton, E. S.: Source Apportionment of PM2.5 in the Southeastern United States Using Solvent-Extractable Organic Compounds as Tracers, Environ. Sci. Technol., 36, 2361-2371, doi:10.1021/es011275x, 2002.
Zheng, M., Ke, L., Edgerton, E. S., Schauer, J. J., Dong, M., and Russell, A. G.: Spatial distribution of carbonaceous aerosol in the southeastern United States using molecular markers and carbon isotope data, J. Geophys. Res.-Atmos., 111, D10S06, doi:10.1029/2005JD006777, 2006.

Zotter, P., El-Haddad, I., Zhang, Y., Hayes, P. L., Zhang, X., Lin, Y.-H., Wacker, L., Schnelle-Kreis, J., Abbaszade, G., Zimmermann, R., Surratt, J. D., Weber, R., Jimenez, J. L., Szidat, S., Baltensperger, U., and Prévôt, A. S. H.: Diurnal cycle of fossil and nonfossil carbon using radiocarbon analyses during CalNex, J. Geophys. Res.-Atmos., 119, 2013JD021114, doi:10.1002/2013JD021114, 2014. 